DOC.20041101.0003

QA: QA

ANL-NBS-GS-000013 REV 01

November 2004

BECHTEL

SAIC COMPANYLC

\title{
Heat Capacity Analysis Report
}

Prepared for:

U.S. Department of Energy

Office of Civilian Radioactive Waste Management

Office of Repository Development

1551 Hillshire Drive

Las Vegas, Nevada 89134-6321

Prepared by:

Bechtel SAIC Company, LLC

1180 Town Center Drive

Las Vegas, Nevada 89144

Under Contract Number

DE-AC28-01RW12101 


\section{DISCLAIMER}

This report was prepared as an account of work sponsored by an agency of the United States Government. Neither the United States Government nor any agency thereof, nor any of their employees, nor any of their contractors, subcontractors or their employees, makes any warranty, express or implied, or assumes any legal liability or responsibility for the accuracy, completeness, or any third party's use or the results of such use of any information, apparatus, product, or process disclosed, or represents that its use would not infringe privately owned rights. Reference herein to any specific commercial product, process, or service by trade name, trademark, manufacturer, or otherwise, does not necessarily constitute or imply its endorsement, recommendation, or favoring by the United States Government or any agency thereof or its contractors or subcontractors. The views and opinions of authors expressed herein do not necessarily state or reflect those of the United States Government or any agency thereof. 
QA: QA

Heat Capacity Analysis Report ANL-NBS-GS-000013 REV 01 November 2004 


\begin{tabular}{|c|c|l|}
\hline \multirow{2}{*}{ OCRWM } & $\begin{array}{c}\text { Scientific Analysis Signature Page/ } \\
\text { Change History }\end{array}$ & Page iii \\
\cline { 3 - 3 } & 1. Total Pages: 100 \\
\hline
\end{tabular}

\section{Scientific Analysis Title}

Heat Capacity Analysis Report

3. DI (including Revision Number)

ANL-NBS-GS-000013 REV 01

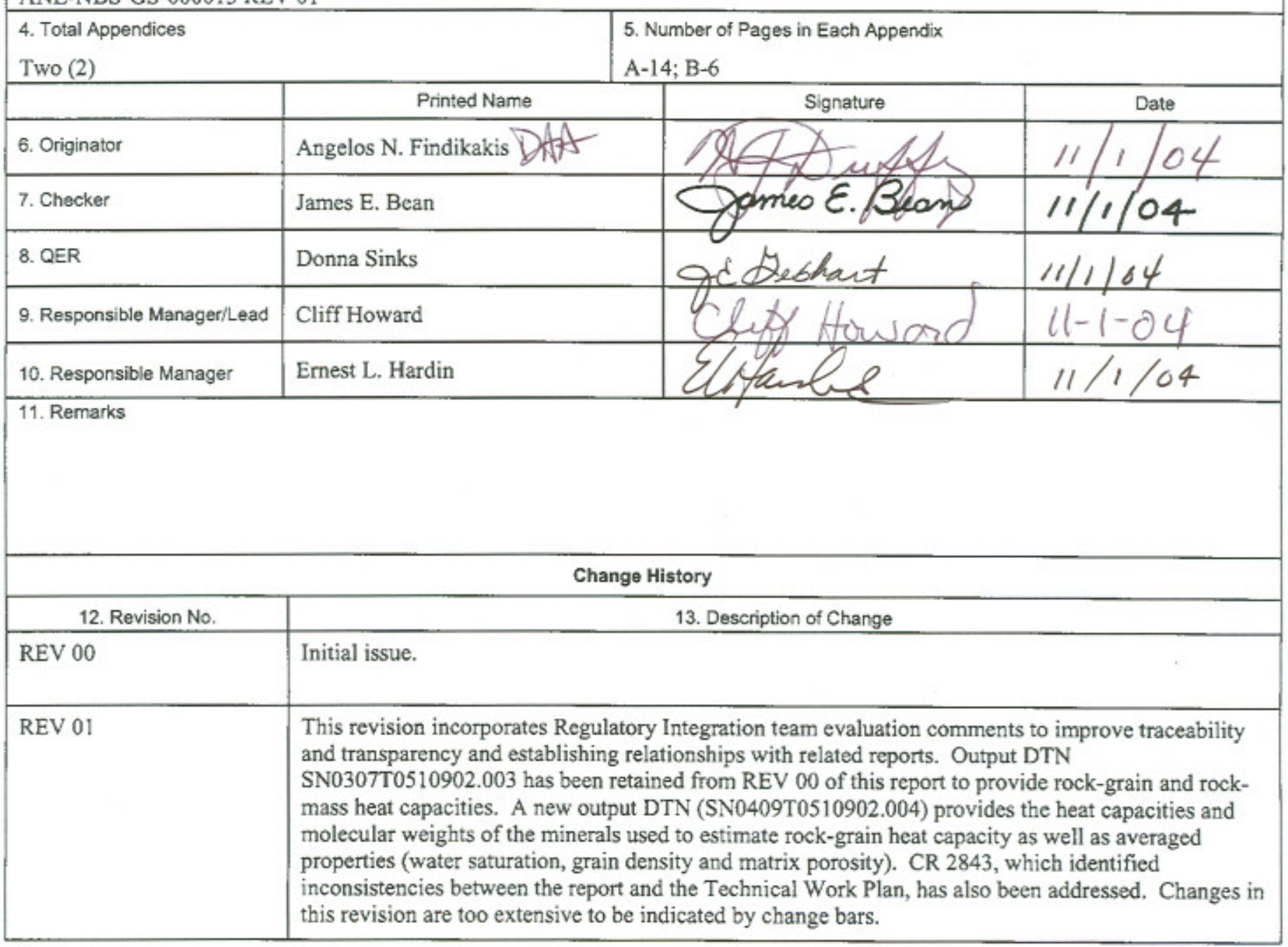




\section{INTENTIONALLY LEFT BLANK}




\section{CONTENTS}

Page

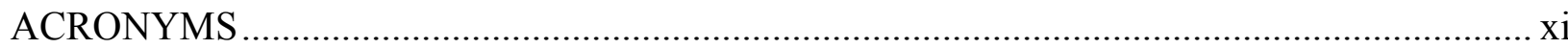

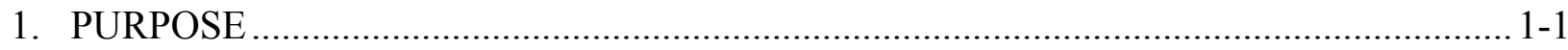

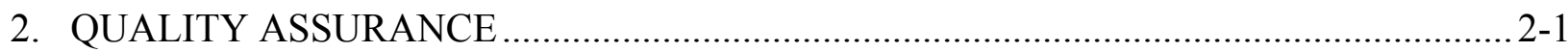

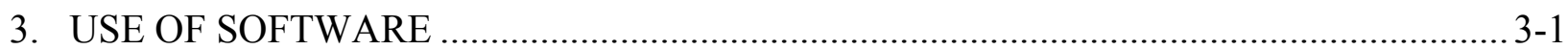

3.1 SOFTWARE TRACKED BY CONFIGURATION MANAGEMENT …...................... 3-1

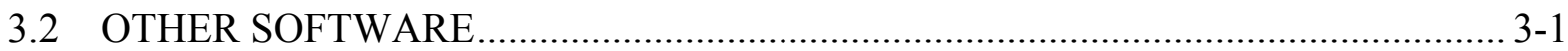

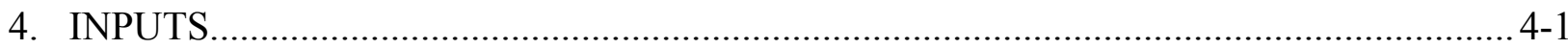

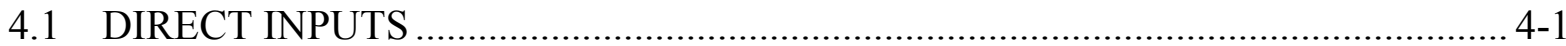

4.1.1 Mineral Abundance Data ……………................................................ 4-1

4.1.2 Mineral Heat Capacity Data................................................................ 4-1

4.1.3 Rock-Matrix Properties Data ………………........................................ 4-4

4.1.4 Lithostratigraphic Contacts Data ……………...................................... 4-4

4.1.5 Physical Properties of Water....................................................................... 4-4

4.1.6 Atomic Weights of Elements ………….................................................. 4-5

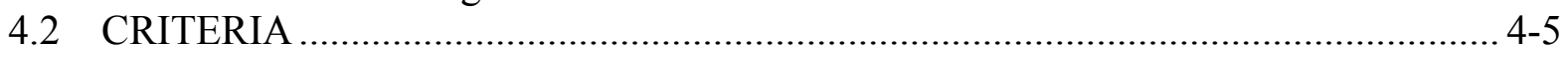

4.2.1 Acceptance Criterion 1 - System Description and Model Integration

Are Adequate …….................................................................................... 4-6

4.2.2 Acceptance Criterion 2 - Data Are Sufficient for Model Justification ......... 4-6

4.2.3 Acceptance Criterion 3 - Data Uncertainty Is Characterized and Propagated Through the Model Abstraction................................................... 4-6

4.2.4 Acceptance Criterion 4 - Model Uncertainty Is Characterized and Propagated Through the Model Abstraction................................................... 4-7

4.3 CODES, STANDARDS, AND REGULATIONS ................................................... 4-7

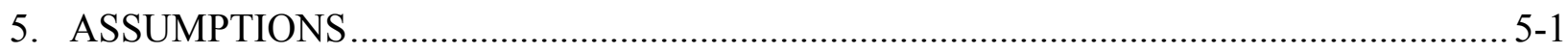

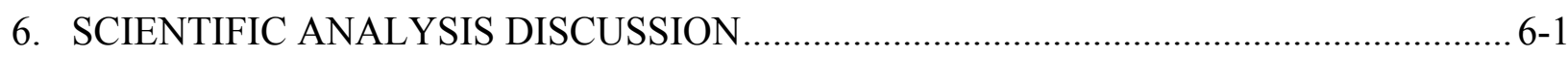

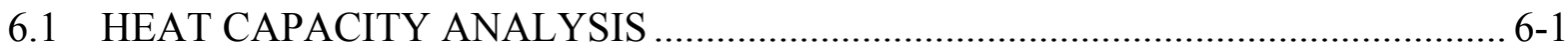

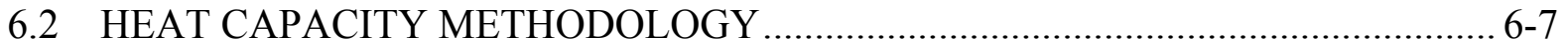

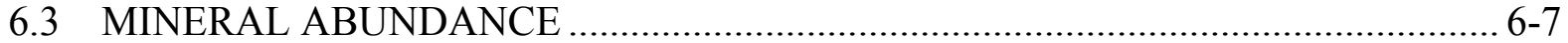

6.4 HEAT CAPACITY REPRESENTATIONS FOR THE MINERAL GROUPS ......... 6-23

6.5 HEAT CAPACITY VALUES OF THE TEN MINERAL GROUPS …..................... 6-25

6.6 CALCULATION OF ROCK-GRAIN HEAT CAPACITY ……............................... 6-26

6.7 CALCULATION OF ROCK-MASS HEAT CAPACITY ……………………......... 6-28

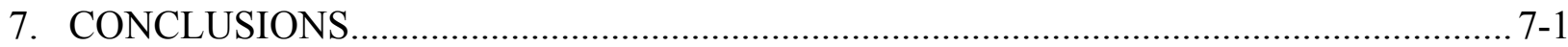

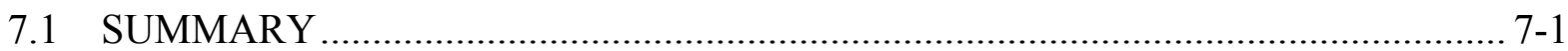

7.2 YUCCA MOUNTAIN REVIEW PLAN CRITERIA ASSESSMENT......................... 7-1 


\section{CONTENTS (Continued)}

Page

7.2.1 Acceptance Criterion 1 - System Description and Model Integration Are Adequate $7-2$

7.2.2 Acceptance Criterion 2 - Data Are Sufficient for Model Justification ......... 7-2

7.2.3 Acceptance Criterion 3 - Data Uncertainty Is Characterized and Propagated Through the Model Abstraction.

7.2.4 Acceptance Criterion 4 - Model Uncertainty Is Characterized and Propagated Through the Model Abstraction.

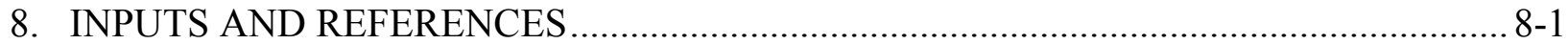

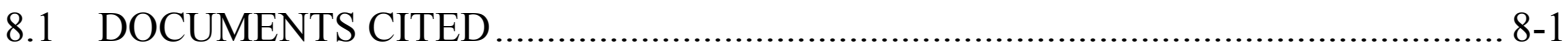

8.2 CODES, STANDARDS, REGULATIONS, AND PROCEDURES ……………........ 8-4

8.3 SOURCE DATA, LISTED BY DATA TRACKING NUMBER ……………............ 8-4

8.4 OUTPUT DATA, LISTED BY DATA TRACKING NUMBER ……….................. 8-5

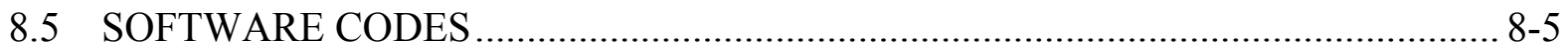

APPENDIX A - HEAT CAPACITY OF THE TEN MINERAL GROUPS................................ A-1 APPENDIX B - COMPARISON OF DEVELOPED HEAT CAPACITY VALUES .................. B-1 


\section{FIGURES}

Page

6-1. Locations of Boreholes Used in the Mineralogic Model ...................................... 6-8

6-2. Zeolite Abundance Versus Frequency: Tac1 ............................................................ 6-14

6-3. Zeolite Abundance Versus Frequency: Tac2 ........................................................ 6-15

6-4. Zeolite Abundance Versus Frequency: Tac3 ...................................................... 6-16

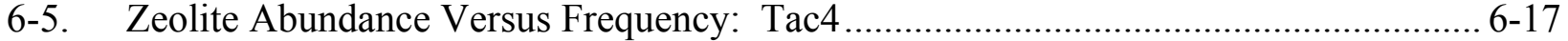

6-6. Zeolite Abundance Versus Frequency: Tptpv1 - Tpbt1 ......................................... 6-18

6-7. Zeolite Abundance Versus Frequency: Tacbt............................................................ 6-19

6-8. Zeolite Abundance Versus Frequency: Tptpv2 ................................................... 6-20

6-9. Rock Moisture Content as a Function of Temperature as Measured from Neutron Logging of Boreholes 79 and 80 During the Drift Scale Test Heating Phase .............. 6-36

A-1. Heat Capacity Versus Temperature: Smectite and Illite ..................................... A-11

A-2. Heat Capacity Versus Temperature: Sorptive Zeolites............................................. A-11

A-3. Heat Capacity Versus Temperature: Tridymite ................................................... A-12

A-4. Heat Capacity Versus Temperature: Cristobalite-Alpha and Quartz......................... A-12 


\section{INTENTIONALLY LEFT BLANK}




\section{TABLES}

Page

3-1. Software Tracked by Configuration Management ................................................. 3-1

4-1. Mineralogy Abundance Data........................................................................................ 4-1

4-2. Mineral Heat Capacity Data .................................................................................... 4-3

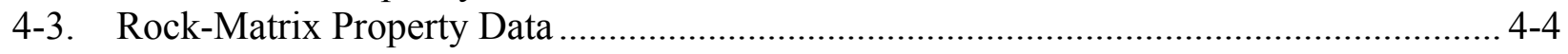

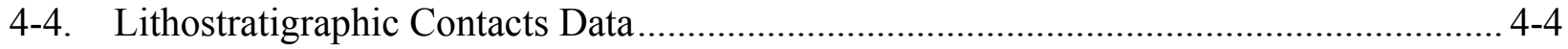

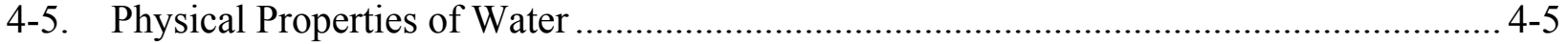

4-6. Atomic Weights of Elements .......................................................................... 4-5

4-7. Applicable Project Requirements and Acceptance Criteria ......................................... 4-5

6-1. Correlation Chart of Model Stratigraphy ............................................................ 6-2

6-2. Mineral Abundance of the Ten Mineral Groups in the Mineralogic Model .................. 6-10

6-3. Mineral Abundance of the Ten Mineral Groups in the Vitric Zones for Layers of the Mineralogic Model....

6-4. Mineral Abundance of the Ten Mineral Groups in the Zeolitic Zones for Layers of the Mineralogic Model .................................................................................. 6-22

6-5. Temperature-Dependant Heat Capacity Equations for Different Minerals................... 6-24

6-6. Rock-Grain Heat Capacities for Lithostratigraphic Units ......................................... 6-29

6-7. Rock-Grain Heat Capacities for Lithostratigraphic Units Tptpv2-Tacbt ..................... 6-30

6-8. Averaged Rock Matrix Properties for Lithostratigraphic Units ................................. 6-33

6-9. Rock-Mass Heat Capacities for Lithostratigraphic Units....................................... 6-37

B-1. Comparison of Oxide and Mineral Summation Methods for Rock-Grain Heat

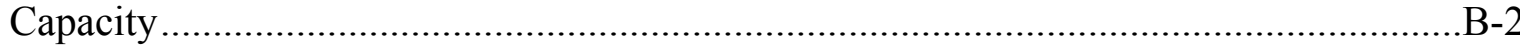




\section{INTENTIONALLY LEFT BLANK}




\section{ACRONYMS}

DTN data tracking number

GFM Geologic Framework Model

ICNZ International Committee on Natural Zeolites

TWP technical work plan

USGS Unites States Geological Survey

UZ unsaturated zone

XRD X-ray diffraction 
INTENTIONALLY LEFT BLANK 


\section{PURPOSE}

The purpose of this report is to provide heat capacity values for the host and surrounding rock layers for the waste repository at Yucca Mountain. The heat capacity representations provided by this analysis are used in unsaturated zone (UZ) flow, transport, and coupled processes numerical modeling activities, and in thermal analyses as part of the design of the repository to support the license application. Among the reports that use the heat capacity values estimated in this report are the Multiscale Thermohydrologic Model report, the Drift Degradation Analysis report, the Ventilation Model and Analysis Report, the Igneous Intrusion Impacts on Waste Packages and Waste Forms report, the Dike/Drift Interactions report, the Drift-Scale Coupled Processes (DST and TH Seepage) Models report, and the In-Drift Natural Convection and Condensation report. The specific objective of this study is to determine the rock-grain and rock-mass heat capacities for the geologic stratigraphy identified in the Mineralogic Model (MM3.0) Report (BSC 2004 [DIRS 170031], Table 1-1). This report provides estimates of the heat capacity for all stratigraphic layers except the Paleozoic, for which the mineralogic abundance data required to estimate the heat capacity are not available. The temperature range of interest in this analysis is $25^{\circ} \mathrm{C}$ to $325^{\circ} \mathrm{C}$. This interval is broken into three separate temperature sub-intervals: $25^{\circ} \mathrm{C}$ to $95^{\circ} \mathrm{C}, 95^{\circ} \mathrm{C}$ to $114^{\circ} \mathrm{C}$, and $114^{\circ} \mathrm{C}$ to $325^{\circ} \mathrm{C}$, which correspond to the preboiling, trans-boiling, and postboiling regimes.

Heat capacity is defined as the amount of energy required to raise the temperature of a unit mass of material by one degree (Nimick and Connolly 1991 [DIRS 100690], p. 5). The rock-grain heat capacity is defined as the heat capacity of the rock solids (minerals), and does not include the effect of water that exists in the rock pores. By comparison, the rock-mass heat capacity considers the heat capacity of both solids and pore water. For temperatures in the trans-boiling regime $\left(95^{\circ} \mathrm{C}\right.$ to $\left.114^{\circ} \mathrm{C}\right)$, the additional energy required to vaporize the pore water is accounted for in the rock-mass heat capacity. The rock-grain heat capacities are intended to be used in models and analyses that explicitly account for the thermodynamic effects of the water within the rock porosity. The rock-mass heat capacities are intended to be used in models and analyses that do not explicitly account for these thermodynamic effects, particularly boiling. The term specific heat is often used synonymously with heat capacity; however, the latter term is used throughout this document.

Three methods for evaluating the heat capacity of rock grains are described in Section 6. The method selected for use in this analysis, the mineral summation method, which is based on Kopp's law (Nimick and Connolly 1991 [DIRS 100690], p. 6), uses the sum of the heat capacities of minerals in a layer weighted by their abundance. The stratigraphic layers and mineral abundance data are found in the Mineralogic Model (MM3.0) Report (BSC 2004 [DIRS 170031]) Data Tracking Number (DTN): LA9908JC831321.001 [DIRS 113495]. The present analysis uses the ten mineral groups incorporated in the mineralogic model (BSC 2004 [DIRS 170031], Section 6.2.3). The layers of the Calico Hills Formation and the adjacent bedded tuff layers exhibit a bimodal composition, and are characterized either as vitric or as zeolitic (BSC 2004 [DIRS 170031], Section 6.3.2). Therefore, heat capacities for the Calico Hills Formation and adjacent bedded tuffs are provided for the entire layer and for the separate vitric and zeolitic regions. 
The input data used in this analysis were averaged for the particular layer under investigation, with the exception of the heat capacity values of the Calico Hills Formation and adjacent layers of bedded tuffs that are separated into vitric and zeolitic regions. In general, the averaged values of heat capacity are appropriate because the layers are compositionally and mechanically homogeneous. However, users of this heat capacity data should be aware of this limitation if a location-specific estimate of heat capacity or spatial variability within a layer is required. For each layer, mean and standard-deviation values are presented for mineral abundance (Section 6.3), rock-grain heat capacity (Section 6.6), and rock-mass heat capacity (Section 6.7). The standard deviations values are presented as a measure of the spread of these parameters around their mean value.

This analysis report addresses activities described in the Technical Work Plan for: Near-Field Environment and Transport Thermal Properties Model and Analysis Reports Integration (BSC 2004 [DIRS 171708], Section 1.2.3) with respect to rock heat capacity. As described in the technical work plan (TWP) (BSC 2004 [DIRS 171708], Section 2.1.5), this heat capacity analysis does not address any features, events, or processes.

A deviation from the TWP (BSC 2004 [DIRS 171708], Section 3.2) concerns the Yucca Mountain Review Plan, Final Report (NRC 2003 [DIRS 163274]) acceptance criteria. The TWP states that the Acceptance Criteria are not relevant to this report because the outputs are not specifically covered by any category but instead provide inputs to downstream numerical models. Contrary to this, the report identifies and discusses the relevant acceptance criteria in Sections 4.2 and 7.2, respectively. Also, the present report deviates from the TWP (BSC 2004 [DIRS 171708], Section 9) by using EARTHVISION (EARTHVISION V5.1, STN: 10174-5.1-00) (Dynamic Graphics 2000 [DIRS 167994]), controlled software not identified in the plan. 


\section{QUALITY ASSURANCE}

Development of this model report and the supporting analyses have been determined to be subject to the Office of Civilian Radioactive Waste Management quality-assurance program (BSC 2004 [DIRS 171708], Section 8.1). Approved quality-assurance procedures identified in the TWP (BSC 2004 [DIRS 171708], Section 4) have been used to conduct and document the activities described in this analysis report. The TWP also identifies the methods used to control the electronic management of data (BSC 2004 [DIRS 171708], Section 8.4) during the analysis and documentation activities. This report has been prepared in accordance with AP-SIII.9Q, Scientific Analyses.

This model report contributes to the analysis and modeling of the UZ, which is a natural barrier and is classified on the Q-List (BSC 2004 [DIRS 168361]) as safety category because it is important to waste isolation, as defined in AP-2.22Q, Classification Analyses and Maintenance of the Q-List. 


\section{INTENTIONALLY LEFT BLANK}




\section{USE OF SOFTWARE}

\subsection{SOFTWARE TRACKED BY CONFIGURATION MANAGEMENT}

EARTHVISION (EARTHVISION V5.1, STN: 10174-5.1-00) (Dynamic Graphics 2000 [DIRS 167994]) was the only software used in this analysis that was subject to software configuration management control. Table 3-1 gives a brief description of the software's functionality. EARTHVISION was selected because it is the leading software for the visualization and evaluation of geologic data. There are no limitations to the use of this software that pertain to the preparation of the data used in the present report.

Table 3-1. Software Tracked by Configuration Management

\begin{tabular}{|c|c|c|c|c|c|}
\hline Code Name & Version & $\begin{array}{c}\text { Software } \\
\text { Tracking } \\
\text { Number }\end{array}$ & Platform & $\begin{array}{c}\text { Operating } \\
\text { System }\end{array}$ & \multicolumn{1}{c|}{ Brief Description } \\
\hline $\begin{array}{l}\text { EARTHVISION } \\
\text { [DIRS 167994] }\end{array}$ & 5.1 & $10174-5.1-00$ & SGI & IRIX 6.5 & $\begin{array}{l}\text { Three-dimensional earth science } \\
\text { modeling package; used in this study } \\
\text { to produce mineral-abundance } \\
\text { statistics pertaining to the ten mineral } \\
\text { groups. }\end{array}$ \\
\hline
\end{tabular}

The software was used to calculate mineral-abundance statistics (average and standard deviation) for the ten mineral species or groups in each model layer considered in this analysis. EARTHVISION includes several modules offering a broad range of capabilities for three-dimensional model building and visualization of geologic data, as well as for calculating basic statistics of these data. The use of the software for estimating the mineral-abundance statistics was within its range of validation, and was run on a Silicon Graphics ${ }^{\circledR}$ Octane ${ }^{\circledR}$ workstation operating under the IRIX Version 6.5 operating system.

\subsection{OTHER SOFTWARE}

Microsoft Excel 2000 was used to calculate the heat capacity values presented in Section 6, and the heat capacity data of minerals presented in Appendix A. As used in this analysis, Microsoft Excel 2000 (a commercial, off-the-shelf software product) is not subject to LP-SI.11Q-BSC, Software Management (Section 2.1). Only standard functions (average and standard deviation) were used, and macros were not utilized in this analysis. The formulas documented in Section 6.1 (Equation 6-1), Section 6.4 (Equations 6-2 to 6-7), Section 6.6 (Equations 6-12, 6-13, 6-17, and 6-18), and Section 6.7 (Equations 6-19 to 6-26) were implemented in the spreadsheets. 


\section{INTENTIONALLY LEFT BLANK}




\section{INPUTS}

\subsection{DIRECT INPUTS}

Inputs used to determine rock-heat capacity include:

1. Mineralogical abundance data;

2. Mineral-species or group-heat capacity data;

3. Rock-matrix properties data, including matrix porosity, matrix saturation, and grain density;

4. Lithostratigraphic contacts; and

5. Physical constants of water, including density, heat capacity, and enthalpy of vaporization.

The input sources for this report are described below. The selection rationale and use of these inputs are described in Section 6.

\subsubsection{Mineral Abundance Data}

The mineral-species and group-abundance data used to calculate heat capacity values were obtained from the Mineralogic Model (MM3.0) Report (BSC 2004 [DIRS 170031]). The input-data source DTN listed in Table 4-1 is the output of that report.

Table 4-1. Mineralogy Abundance Data

\begin{tabular}{|l|l|}
\hline \multicolumn{1}{|c|}{ Data Description } & \multicolumn{1}{c|}{ Source } \\
\hline $\begin{array}{l}\text { Product Output files from the } \\
\text { Mineralogic Model "MM3.0" }\end{array}$ & DTN: LA9908JC831321.001 \\
[DIRS 113495]
\end{tabular}

The Mineralogic Model (MM3.0) Report (BSC 2004 [DIRS 170031]) provides details concerning inputs and modeling techniques that were used to develop the mineralogic-abundance data used as input to this analysis. The mineralogic-abundance input data from DTN: LA9908JC831321.001 [DIRS 113495] are appropriate, because the data were obtained from X-ray diffraction (XRD) analysis of Yucca Mountain borehole samples. The data were provided in the form of weight percents, and are discussed in Section 6.3.

\subsubsection{Mineral Heat Capacity Data}

The temperature-dependent heat capacity equations for the mineral species and groups were obtained from the sources listed in Table 4-2. The majority of the heat capacity values were obtained from DTN: MO0009THRMODYN.001 [DIRS 152576]. Heat capacity data for chabazite, erionite, and stellerite were obtained from Chipera et al. (1995 [DIRS 100025]), for clinoptilolite and for mordenite were obtained from DTN: MO0302SPATHDYN.001 [DIRS 161886] and, for analcime, were obtained from Johnson et al. (1982 [DIRS 106283], p. 744, Equation 4). These data are appropriate, because they provide heat capacity 
representations for the mineral groups identified in the Mineralogic Model (MM3.0) Report (BSC 2004 [DIRS 170031], Section 6.2.3).

The heat capacity values for tridymite and silica glasses were obtained from:

Thermodynamic Properties of Minerals and Related Substances at $298.15 \mathrm{~K}$ and 1 Bar (10 Pascals) Pressure and at Higher Temperatures (Robie et al. 1979 [DIRS 107109], p. 218),

and

Thermodynamic Properties of Minerals and Related Substances at $298.15 \mathrm{~K}$ and 1 Bar $\left(10^{5}\right.$ Pascals) Pressure and at Higher Temperatures (Robie and Hemingway 1995 [DIRS 153683], pp. 31 to 40, 50, and 58 to 66).

These data have been determined to be suitable for their intended use in accordance with AP-SIII.9Q, as noted below:

1. Chipera et al. (1995 [DIRS 100025])

- Extent to which the data demonstrate the properties of interest:

Use of these values is appropriate because these data are specific for chabazite, erionite, and stellerite, and specific for the temperature range of interest.

- Reliability of the data source:

This reference is from the book Natural Zeolites '93: Occurrence, Properties, Use, Proceedings of the 4th International Conference on the Occurrence, Properties, and Utilization of Natural Zeolites, published by the International Committee on Natural Zeolites (ICNZ). The ICNZ was created in 1976 to promote and encourage the growing interest in natural zeolite materials throughout the scientific and technical community. In its twenty-two-year history, ICNZ has served as a focal point of worldwide interest in natural zeolites and has been instrumental in the organization of conferences, field trips, symposia, and special sessions at national and international meetings on the subject of natural zeolites.

2. Johnson et al. (1982 [DIRS 106283], p. 744, Equation 4)

- Extent to which the data demonstrate the properties of interest:

Use of these values is appropriate because these data are specific for analcime and for the temperature range of interest.

- Reliability of the data source:

This reference is a peer-reviewed paper published in the prestigious journal American Mineralogist, the journal of the Mineralogical Society of America. 
3. Robie et al. (1979 [DIRS 107109], p. 218):

- Extent to which the data demonstrate the properties of interest:

Use of these values is appropriate because these data are specific for tridymite and for the temperature range of interest.

- Reliability of the data source:

This reference contains these data and was produced by the United States Geological Survey (USGS), a premier federal source of earth science data. These data were published as USGS bulletins, which undergo several levels of strict internal review prior to their release to the public.

4. Robie and Hemingway (1995 [DIRS 153683], pp. 31 to 40, 50, and 58 to 66):

- Extent to which the data demonstrate the properties of interest:

Use of these values is appropriate because these data are specific for silica glass and for the temperature range of interest.

- Reliability of the data source:

This reference contains these data and was produced by the USGS, a premier federal source of earth science data. These data were published as USGS bulletins, which undergo several levels of strict internal review prior to their release to the public.

The heat capacity values assigned to each mineral species or group are provided in Appendix A.

Table 4-2. Mineral Heat Capacity Data

\begin{tabular}{|l|l|}
\hline \multicolumn{1}{|c|}{ Data Description } & \multicolumn{1}{c|}{ Source } \\
\hline $\begin{array}{l}\text { Heat capacity of smectite, illite, cristobalite, quartz, } \\
\text { feldspar, muscovite, and calcite }\end{array}$ & $\begin{array}{l}\text { DTN: MO0009THRMODYN.001 } \\
\text { [DIRS 152576] }\end{array}$ \\
\hline Heat capacity of tridymite & $\begin{array}{l}\text { Robie et al. } \\
(1979 \text { [DIRS 107109] })\end{array}$ \\
\hline Heat capacity of various glasses & $\begin{array}{l}\text { Robie and Hemingway } \\
(1995 \text { [DIRS 153683] })\end{array}$ \\
\hline Heat capacity of chabazite, erionite, and stellerite & $\begin{array}{l}\text { Chipera et al. } \\
(1995 \text { [DIRS 100025] })\end{array}$ \\
\hline Heat capacity of clinoptilolite and mordenite & $\begin{array}{l}\text { MO0302SPATHDYN.001 } \\
\text { [DIRS 161886] }\end{array}$ \\
\hline Heat capacity of analcime & $\begin{array}{l}\text { Johnson et al. } \\
(1982 \text { [DIRS 106283], p. 744, } \\
\text { Equation 4) }\end{array}$ \\
\hline
\end{tabular}




\subsubsection{Rock-Matrix Properties Data}

The rock-matrix properties data for grain density, matrix porosity, and matrix saturation were measured from core samples obtained from Yucca Mountain boreholes. The DTNs from which the data were obtained, and the boreholes from which the data were collected, are listed in Table 4-3.

Table 4-3. Rock-Matrix Property Data

\begin{tabular}{|l|l|}
\hline \multicolumn{1}{|c|}{ Data Description } & \multicolumn{1}{|c|}{ Source } \\
\hline Matrix properties data for boreholes: & DTN: MO0109HYMXPROP.001 \\
USW UZ-N11, N15, N16, N17, N27, N31, & [DIRS 155989] \\
N32, N33, N34, N35, N36, N37, N38, N53, & \\
N54, N55, N57, N58, N59, N61, N62, N63, & \\
and N64; UE-25 UZ\#16, SD-7, SD-9, and & \\
$\begin{array}{l}\text { SD-12; USW NRG 7/7A, USW UZ-7A, } \\
\text { USW UZ-14; and USW NRG-6 }\end{array}$ & \\
\hline $\begin{array}{l}\text { Matrix properties data for borehole core } \\
\text { samples from USW SD-6 }\end{array}$ & DTN: GS980808312242.014 \\
\hline Matrix properties data for & [DIRS 106748] \\
borehole USW WT-24 & DTN: GS980708312242.010 \\
\hline
\end{tabular}

These DTNs contain qualified data; therefore, their use is appropriate.

\subsubsection{Lithostratigraphic Contacts Data}

In order to organize the core-derived matrix property measurements discussed in Section 4.1.3, it was necessary to sort them based on the borehole lithostratigraphic contacts. The borehole lithostratigraphic contacts are provided by the two DTNs listed in Table 4-4.

Table 4-4. Lithostratigraphic Contacts Data

\begin{tabular}{|l|l|}
\hline \multicolumn{1}{|c|}{ Data Description } & \multicolumn{1}{c|}{ Source } \\
\hline $\begin{array}{l}\text { Lithostratigraphic contacts for } \\
\text { boreholes }\end{array}$ & $\begin{array}{l}\text { DTN: MO0004QGFMPICK.000 } \\
\text { [DIRS 152554] }\end{array}$ \\
\hline $\begin{array}{l}\text { UZ lithostratigraphic contacts in } \\
\text { borehole USW SD-6 }\end{array}$ & $\begin{array}{l}\text { DTN: SNF40060298001.001 } \\
\text { [DIRS 107372] }\end{array}$ \\
\hline
\end{tabular}

These DTNs contain qualified data; therefore, their use is appropriate.

\subsubsection{Physical Properties of Water}

Three physical properties for water (density, heat capacity, and the enthalpy of vaporization) are required to calculate the rock-mass heat capacity of the layers. These constants were obtained from the CRC Handbook of Chemistry and Physics (Lide 2002 [DIRS 160832], pp. 6-3 and 6-4). This is a standard industry reference; therefore, the use of values it provides is appropriate. 
Table 4-5. Physical Properties of Water

\begin{tabular}{|l|c|}
\hline \multicolumn{1}{|c|}{ Data Description } & Source \\
\hline $\begin{array}{l}\text { Density, heat capacity, and enthalpy of } \\
\text { vaporization of water }\end{array}$ & Lide 2002 [DIRS 160832] \\
\hline
\end{tabular}

\subsubsection{Atomic Weights of Elements}

The atomic weights of aluminum, barium, calcium, hydrogen, iron, magnesium, manganese, oxygen, potassium, silicon, sodium, and strontium were used to calculate the molecular weight of different minerals. These constants were obtained from the CRC Handbook of Chemistry and Physics (Lide 2002 [DIRS 160832], pp. 1-12 and 1-13). This is a standard industry reference; therefore, the use of values it provides is appropriate. The source of the atomic weights is also provided in Table 4-6.

Table 4-6. Atomic Weights of Elements

\begin{tabular}{|l|c|}
\hline \multicolumn{1}{|c|}{ Data Description } & Source \\
\hline Atomic weights of $\mathrm{Al}, \mathrm{Ba}, \mathrm{Ca}, \mathrm{H}, \mathrm{Fe}$, & Lide 2002 [DIRS 160832] \\
$\mathrm{Mg}, \mathrm{Mn}, \mathrm{O}, \mathrm{K}, \mathrm{Si}, \mathrm{Na}, \mathrm{Sr}$ & \\
\hline
\end{tabular}

\subsection{CRITERIA}

The Yucca Mountain Project Requirements Document (Canori and Leitner 2003 [DIRS 166275]) identifies the high-level requirements for the Yucca Mountain Project. The requirements that pertain to this scientific analysis report, and their link to 10 CFR 63 [DIRS 156605], are shown in Table 4-7 (Yucca Mountain Review Plan, Final Report (NRC 2003 [DIRS 163274])). The Yucca Mountain Review Plan, Final Report (NRC 2003 [DIRS 163274]) lists acceptance criteria pertaining to these requirements. Criteria that are applicable to this scientific analysis report are listed in Table 4-7 and described below.

Table 4-7. Applicable Project Requirements and Acceptance Criteria

\begin{tabular}{|c|c|c|c|}
\hline $\begin{array}{c}\text { Requirement } \\
\text { Number }\end{array}$ & Title & $\begin{array}{c}\text { 10 CFR 63 Link } \\
\text { [DIRS 156605] }\end{array}$ & $\begin{array}{c}\text { Yucca Mountain Review Plan, Final } \\
\text { Report (NRC 2003 [DIRS 163274]) } \\
\text { Acceptance Criteria }\end{array}$ \\
\hline PRD-002/T-002 & $\begin{array}{c}\text { Requirements for } \\
\text { Performance Assessment }\end{array}$ & 10 CFR 63.114 & 2.2 .1 .3 .3 .3 , Criteria 1, 2, 3, and 4 \\
\hline
\end{tabular}

Work described in this model report supports these requirements, but more specific criteria exist in Yucca Mountain Review Plan, Final Report (NRC 2003 [DIRS 163274]). The criteria established for the quantity and chemistry of water that comes into contact with engineered barriers and waste forms as presented in Section 2.2.1.3.3.3 of NRC (2003 [DIRS 163274]) and 10 CFR 63.114(a)-(c) and (e)-(g) [DIRS 156605] are applicable to this model report. The criteria and subcriteria relevant to this model report are presented in the following subsections, and an assessment of how these criteria are addressed is provided in Section 7.2 of this report. 


\subsubsection{Acceptance Criterion 1 - System Description and Model Integration Are Adequate}

(2) The abstraction of the quantity and chemistry of water contacting engineered barriers and waste forms uses assumptions, technical bases, data, and models, that are appropriate and consistent with other related U.S. Department of Energy abstractions. For example, the assumptions used for the quantity and chemistry of water contacting engineered barriers and waste forms are consistent with the abstractions of "Degradation of Engineered Barriers" (Section 2.2.1.3.1); "Mechanical Disruption of Waste Packages" (Section 2.2.1.3.2); "Radionuclide Release Rates and Solubility Limits" (Section 2.2.1.3.4); "Climate and Infiltration" (Section 2.2.1.3.5); and "Flow Paths in the Unsaturated Zone" (Section 2.2.1.3.6). The descriptions and technical bases provide transparent and traceable support for the abstraction of quantity and chemistry of water contacting engineered barriers and waste forms.

\subsubsection{Acceptance Criterion 2 - Data Are Sufficient for Model Justification}

(1) Geological, hydrological, and geochemical values used in the license application are adequately justified. Adequate description of how the data were used, interpreted, and appropriately synthesized into the parameters is provided.

(2) Sufficient data were collected on the characteristics of the natural system and engineered materials to establish initial and boundary conditions for conceptual models of thermal-hydrologic-mechanical-chemical coupled processes, that affect seepage and flow and the waste package chemical environment.

\subsubsection{Acceptance Criterion 3 - Data Uncertainty Is Characterized and Propagated Through the Model Abstraction}

(1) Models use parameter values, assumed ranges, probability distributions, and bounding assumptions that are technically defensible, reasonably account for uncertainties and variabilities, and do not result in an under-representation of the risk estimate.

(2) Parameter values, assumed ranges, probability distributions, and bounding assumptions used in the total system performance assessment calculations of quantity and chemistry of water contacting engineered barriers and waste forms are technically defensible and reasonable, based on data from the Yucca Mountain region (e.g., results from large block and drift-scale heater and niche tests), and a combination of techniques that may include laboratory experiments, field measurements, natural analog research, and process-level modeling studies.

(3) Input values used in the total system performance assessment calculations of quantity and chemistry of water contacting engineered barriers (e.g., drip shield and waste package) are consistent with the initial and boundary conditions and the assumptions of the conceptual models and design concepts for the Yucca Mountain site. Correlations between input values are appropriately established in the U.S. Department of Energy total system performance assessment. Parameters 
used to define initial conditions, boundary conditions, and computational domain in sensitivity analyses involving coupled thermal-hydrologic-mechanicalchemical effects on seepage and flow, the waste package chemical environment, and the chemical environment for radionuclide release, are consistent with available data. Reasonable or conservative ranges of parameters or functional relations are established.

(4) Adequate representation of uncertainties in the characteristics of the natural system and engineered materials is provided in parameter development for conceptual models, process-level models, and alternative conceptual models. The U.S. Department of Energy may constrain these uncertainties using sensitivity analyses or conservative limits. For example, the U.S. Department of Energy demonstrates how parameters used to describe flow through the engineered barrier system bound the effects of excavation-induced changes.

\subsubsection{Acceptance Criterion 4 - Model Uncertainty Is Characterized and Propagated Through the Model Abstraction}

(2) Alternative modeling approaches are considered and the selected modeling approach is consistent with available data and current scientific understanding. A description that includes a discussion of alternative modeling approaches not considered in the final analysis and the limitations and uncertainties of the chosen model is provided;

\subsection{CODES, STANDARDS, AND REGULATIONS}

No codes, standards, or regulations are applicable to the analysis documented in this report. 


\section{INTENTIONALLY LEFT BLANK}




\section{ASSUMPTIONS}

1. The heat capacity of a mineral composite is equal to the sum of the heat capacities of its mineral components, each weighted by its abundance. This is described mathematically by Equation 5-1:

$$
C_{p, g}=\sum_{j=1}^{j=n} x_{j} C_{p_{j}}
$$

where the variables $x_{j}$ and $C_{p_{j}}$ are respectively defined as the abundance (weight fraction) and heat capacity of mineral $j$; $n$ is the number of mineral components; and $C_{p, g}$ is the heat capacity of the rock grain.

This is based on Kopp's law, which states that the heat capacity of a solid compound is equal to the sum of the heat capacities of its constituents (Nimick and Connolly 1991 [DIRS 100690], p. 6). Contributions to the heat capacity not accounted for by Kopp's law arise from order/disorder phenomena in crystals, rotational movement of atoms, and magnetic and electric effects. At temperatures significantly removed from absolute zero, the Kopp's law approximation is quite good (Nimick and Connolly 1991 [DIRS 100690], p. 6), Robinson and Haas (1983 [DIRS 107148], pp. 548 to 551). Berryman (1995 [DIRS 159696], pp. 218 and 219) has shown that a temperature-dependent correction to Kopp's law should be applied, but the correction is small at temperatures less than $500^{\circ} \mathrm{C}$. The temperature range of interest for this study, $25^{\circ} \mathrm{C}$ to $325^{\circ} \mathrm{C}$, is well below $500^{\circ} \mathrm{C}$; therefore, the use of Kopp's law is appropriate.

2. The contribution of the fracture porosity to the rock heat mass capacity is negligible.

Fracture- and matrix-property estimates for the UZ layers are provided in BSC (2004 [DIRS 170038], Tables 6-5 and 6-6). The fracture porosities range from $1.6 \times 10^{-4}$ to $2.4 \times 10^{-2}$, with the majority of the layers having less than $1 \times 10^{-2}$ fracture porosity. The relative contribution of fracture porosity to the total porosity (fracture plus matrix porosity) is small; therefore, the contribution of fracture porosity to the evaluation of rock mass heat capacity may be ignored.

3. For the mineralogic model layers 2 (Tund) and 3 (Tctlv-Tctbt), data from neighboring layers were used to provide estimates of the rock-matrix property parameters (matrix saturation, grain density, and matrix porosity). (See Section 6 for correlation between the mineralogic model and stratigraphic nomenclature). Specifically:

- The saturation values in layers 4 (Tctuc-Tctlc) and 5 (Tcblv-Tctuv), above layers 2 (Tund) and 3 (Tctlv-Tctbt), indicate fully saturated conditions; therefore, a matrix water saturation of 1.0 (fully saturated) was used for mineralogic model layers 2 and 3.

- The grain density value of $2.39 \mathrm{~g} / \mathrm{cm} 3$ was used from layer 4 (Tctuc-Tctlc). 
- The matrix porosity value of 0.25 was selected, because it was approximately midway between the porosity values of the two preceding layers, layers 4 (Tctuc-Tctlc) and 5 (Tcblv-Tctuv). Justification for this selection is provided by the similar values in these two layers.

The impact of this selection is minimal, since these layers are located below the water table, and the importance of the heat capacity (rock grain and rock mass) of the layers is not significant. Because of their distance from the repository horizon, layers below the water table will experience a very small temperature rise. Therefore, the thermal properties of these layers are of secondary importance.

4. In the pre-boiling temperature range $\left(25^{\circ} \mathrm{C}\right.$ to $\left.95^{\circ} \mathrm{C}\right)$, the temperature dependence of the physical properties of water is negligible and an average value can be used in the calculation of the heat capacity. Specifically:

- The value $4190 \mathrm{~J} / \mathrm{kg}-\mathrm{K}$ was used for the heat capacity of water, which corresponds to the average value over the $20^{\circ} \mathrm{C}$ to $100^{\circ} \mathrm{C}$ temperature range $(C R C$ Handbook of Chemistry and Physics (Lide 2002 [DIRS 160832], p. 6-3)). Refer to output DTN: SN0307T0510902.003, Water Constants sheet in the rock_mass_heat_capacity.xls Excel workbook.

- The value $981 \mathrm{~kg} / \mathrm{m}^{3}$ was used for the density of water, which corresponds to the average value over the $20^{\circ} \mathrm{C}$ to $95^{\circ} \mathrm{C}$ temperature range (CRC Handbook of Chemistry and Physics (Lide 2002 [DIRS 160832], p. 6-3)). Refer to output DTN: SN0307T0510902.003, Water Constants sheet in the rock_mass_heat_capacity.xls Excel workbook.

5. The heat capacity data for the mineral groups used to estimate the heat capacity of the rock are discussed Section 6.5. The following specific simplifications and assumptions were made for mineral species that are combined into mineral groups and that share a common structure and composition:

- The heat capacity values for tridymite, quartz, analcime, and calcite were used as listed in Appendix A.

- Smectite and Illite: The heat capacity values of these two minerals, smectite and illite, are very similar (Figure A-1); therefore, to simplify the rock-grain heat capacity calculation, the heat capacity curve of smectite was used to represent both smectite and illite. Additional details are presented in Appendix A, Section A1.

- Sorptive Zeolites: The mineral abundance of the sorptive zeolites, provided by DTN: LA9908JC831321.001 [DIRS 113495], is given for the mineral group rather than for the individual minerals; therefore, the heat capacities of the sorptive zeolitic minerals (clinoptilolite, mordenite, chabazite, erionite, and stellerite) were averaged together. As shown in Appendix A, Section A2, and illustrated in Figure A-2, with the exception of clinoptilolite, the heat capacity values of these zeolitic minerals are similar. Averaging the heat capacity values of these five minerals, to produce the heat capacity value for the 
sorptive zeolite group, is consistent with the group abundance data provided in DTN: LA9908JC831321.001 [DIRS 113495].

- The heat capacity of the sorptive zeolite, heulandite, was not directly included in the average heat capacity of the group. The minerals, clinoptilolite and heulandite, based on XRD analysis, have the same crystalline structure (BSC 2004 [DIRS 170031], p. 6-21); therefore, the heat capacity of clinoptilolite was used to represent the heat capacity of heulandite. Even though heulandite is a fairly common mineral (BSC 2004 [DIRS 170031], p. 6-21), its similar structure and composition, and the zeolites' overall similarity in heat capacity values, indicate that using clinoptilolite as a surrogate will not have a significant impact on the zeolite group heat capacity value. The difference between the heat capacity of heulandite and clinoptilolite is about 6 percent or less.

- Cristobalite + Opal CT: The heat capacity value of Opal-CT is not available. Opal-CT is a hydrous cryptocrystalline form of cristobalite (Deer et al. 1966 [DIRS 102773], p. 351). Due to the similarities in their composition and structure, the heat capacity of cristobalite is used to represent Opal-CT.

- Feldspar: There are no direct measurements of the composition of Yucca Mountain feldspar (as phenocrysts or as groundmass); therefore, the feldspar mineral species have not been determined. The plagioclase feldspars (sodium-calcium solid solution series) are common in basic to intermediate lavas (Deer et al. 1966 [DIRS 102773], p. 335). The extrusive ash fall and ash-flow tuffs are more silicic in composition ranging from quartz latites to rhyolites (Peterman and Cloke 2002 [DIRS 162576], Table 1). Therefore, the dominant feldspar is most likely the K-feldspar (sodium-potassium solid solution series) (Deer et al. 1966 [DIRS 102773], p. 335). Normative calculations, based on major element analysis (DTN: GS000308313211.001 [DIRS 162015]) performed on samples from the repository horizon (Tptpul, Tptpmn, Tptpll, and Tptln), indicate that the primary feldspar is an alkali feldspar (sodium-potassium solid solution series) (Peterman and Cloke 2002 [DIRS 162576], Tables 4 and 5). Because of their identical structure and similar composition (sodium-potassium solid solution series, albite to orthoclase), the heat capacity for K-feldspar obtained from DTN: MO0009THRMODYN.001 [DIRS 152576] was used to represent the heat capacity of Yucca-Mountain feldspars. Because of the strong similarities between K-feldspar and the feldspars at Yucca Mountain, the difference, if any, between the heat capacities of the two is insignificant.

- Glass (Vitrophyre): No direct measurements of the heat capacity of the Yucca Mountain volcanic glass (vitrophyre) exist. Heat capacities of 12 glasses given in Thermodynamic Properties of Minerals and Related Substances at $298.15 \mathrm{~K}$ and 1 Bar (10 ${ }^{5}$ Pascals) Pressure and at Higher Temperatures (Robie and Hemingway 1995 [DIRS 153683], pp. 31 to 40, 50, and 58 to 66) were examined (Appendix A) and averaged together, to provide an appropriate representation of the heat capacity value of volcanic glass. This average value is used because there are no direct measurements of the composition of the individual vitrophyre glasses at Yucca Mountain.

- Mica: The heat capacity data used for mica are that of muscovite, and were obtained from DTN: MO0009THRMODYN.001 [DIRS 152576]. Another common mica mineral is 
biotite; however, heat capacity data for biotite were not available. Since muscovite and biotite have identical structures (sheet silicates), and are compositionally similar (muscovite is aluminum rich; biotite is iron rich) (Deer et al. 1966 [DIRS 102773], pp. 201 and 211), the heat capacity of muscovite is used to represent mica. It is also noted that mica is a minor phase in the tuff units.

6. The boiling point of water is $95^{\circ} \mathrm{C}$.

Nimick and Connolly (1991 [DIRS 100690], p. 37) have estimated that for the range of repository elevations the boiling point of water is in the range of $95.2^{\circ} \mathrm{C}$ to $97.3^{\circ} \mathrm{C}$. The lower value of $95^{\circ} \mathrm{C}$ is adopted for the calculations of the heat capacity presented in this report. 


\section{SCIENTIFIC ANALYSIS DISCUSSION}

Heat capacity is an input parameter that is important to thermal modeling, to thermal-hydrologic modeling, and to coupled thermal-mechanical modeling. The heat capacity of a substance is the amount of energy required to change the temperature of a unit mass by one degree, and has units in energy per unit mass per degree (Nimick and Connolly 1991 [DIRS 100690], p. 5). For solid materials, heat capacity is virtually independent of changes in pressure, but is strongly dependent on temperature. Heat capacity is a major component of the accumulation term in the conservation-of-energy equation and, as such, can be a significant contributing parameter in modeling heat transport for the repository.

The heat capacity representations provided by this analysis are used in thermal and thermal-hydrologic numerical modeling activities, and in the design of the repository to support the license application.

The development of heat capacity in this report is based on the use of mineralogic abundances defined by the Mineralogic Model (MM3.0) Report (BSC 2004 [DIRS 170031]). The mineralogic model separates the Yucca Mountain stratigraphic column into 26 layers. These stratigraphic divisions have been used in this analysis. The correlation between the geologic stratigraphy units of the mineralogic model and those of the Geologic Framework Model (GFM) (DTN: MO9901MWDGFM31.000 [DIRS 103769]) are shown in Table 6-1.

The temperature range of interest in this analysis is $25^{\circ} \mathrm{C}$ to $325^{\circ} \mathrm{C}$, and has been broken into three temperature intervals: $25^{\circ} \mathrm{C}$ to $95^{\circ} \mathrm{C}, 95^{\circ} \mathrm{C}$ to $114^{\circ} \mathrm{C}$, and $114^{\circ} \mathrm{C}$ to $325^{\circ} \mathrm{C}$, which correspond to preboiling, trans-boiling, and postboiling regimes. For this analysis, the mineral heat capacities are calculated at one-degree (Celsius) intervals, and are then averaged over each temperature range. The mineral heat capacities are then weighted by mineral abundances and summed to determine the rock-grain heat capacities. The rock-grain-heat capacity values presented for the temperature ranges $\left(25^{\circ} \mathrm{C}\right.$ to $325^{\circ} \mathrm{C}, 25^{\circ} \mathrm{C}$ to $95^{\circ} \mathrm{C}, 95^{\circ} \mathrm{C}$ to $114^{\circ} \mathrm{C}$, and $114^{\circ} \mathrm{C}$ to $325^{\circ} \mathrm{C}$ ) are calculated as an average over the specified temperature range.

\subsection{HEAT CAPACITY ANALYSIS}

There are several methods that can be used to determine rock-grain heat capacity. Nimick and Connolly (1991 [DIRS 100690], pp. 5 to 11) summarized three different methods: mineral summation, oxide summation, and fictive-oxide mineral-component. A brief summary of each technique is provided in the following paragraphs. The available input data constrains the selection of the analytical technique. 
Table 6-1. Correlation Chart of Model Stratigraphy

\begin{tabular}{|c|c|c|c|c|}
\hline Stratigraphic Unit ${ }^{a, b}$ & \multirow[t]{2}{*}{ Abbreviation $^{\mathrm{a}}$} & \multirow[t]{2}{*}{ 迹 } & \multirow[t]{2}{*}{$\begin{array}{l}\text { Geologic } \\
\text { Framework } \\
\text { Model Unit }^{d}\end{array}$} & \multirow[t]{2}{*}{$\begin{array}{l}\text { Mineralogic } \\
\text { Model Unit }\end{array}$} \\
\hline 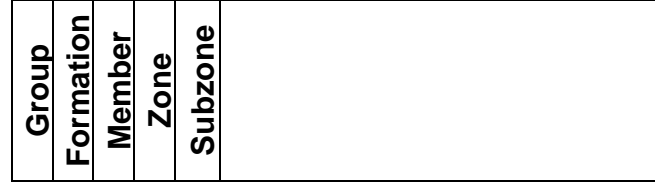 & & & & \\
\hline Alluvium and Colluvium & Qal, Qc & & Alluvium (only) & \multirow{32}{*}{$\begin{array}{c}\text { Sequence } 22 \\
\text { (Layer 26) } \\
\text { Alluvium- } \\
\text { Tpc_un }\end{array}$} \\
\hline Timber Mountain Group & $\mathrm{Tm}$ & & & \\
\hline Rainier Mesa Tuff & Tmr & & \multirow{18}{*}{$\begin{array}{c}\text { Crystal-Rich } \\
\text { Tiva and } \\
\text { Post-Tiva }\end{array}$} & \\
\hline Paintbrush Group & $\mathrm{Tp}$ & & & \\
\hline Post-tuff unit " $x$ " bedded tuff & Tpbt6 & & & \\
\hline Tuff unit "x"e & Tpki (informal) & & & \\
\hline Pre-tuff unit " $x$ " bedded tuff & Tpbt5 & & & \\
\hline Tiva Canyon Tuff & Tpc & & & \\
\hline Crystal-Rich Member & Tpcr & & & \\
\hline Vitric zone & Tpcrv & & & \\
\hline Nonwelded subzone & Tpcrv3 & & & \\
\hline Moderately welded subzone & Tpcrv2 & & & \\
\hline Densely welded subzone & Tpcrv1 & & & \\
\hline Nonlithophysal subzone & Tpcrn & & & \\
\hline \begin{tabular}{|l|} 
Subvitrophyre-transition subzone \\
\end{tabular} & Tpcrn4 & & & \\
\hline Pumice-poor subzone & Tpcrn3 & & & \\
\hline Mixed-pumice subzone & Tpcrn2 & & & \\
\hline Crystal-transition subzone & Tpcrn1 & & & \\
\hline Lithophysal zone & Tpcrl & & & \\
\hline \begin{tabular}{|l|} 
Crystal-transition subzone \\
\end{tabular} & Tpcrl1 & & & \\
\hline Crystal-Poor Member & Tpcp & & \multirow[b]{11}{*}{ Tрср } & \\
\hline Upper lithophysal zone & Tpcpul & & & \\
\hline Spherulite-rich subzone & Tpcpul1 & & & \\
\hline Middle nonlithophysal zone & Tpcpmn & & & \\
\hline Upper subzone & Tpcpmn3 & & & \\
\hline Lithophysal subzone & Tpcpmn2 & & & \\
\hline Lower subzone & Tpcpmn1 & & & \\
\hline Lower lithophysal zone & Tpcpll & & & \\
\hline Hackly-fractured subzone & Tpcpllh & & & \\
\hline Lower nonlithophysal zone & Tpcpln & & & \\
\hline Hackly subzone & Tpcplnh & & & \\
\hline Columnar subzone & Tpcplnc & & \multirow[t]{2}{*}{ TpcLD } & \\
\hline Vitric zone & Tpcpv & & & \\
\hline \begin{tabular}{|l|} 
Densely welded subzone \\
\end{tabular} & Tpcpv3 & & Tpcpv3 & Sequence 21 \\
\hline Moderately welded subzone & Tpcpv2 & & Tpcpv2 & $\begin{array}{c}\text { (Layer 25) } \\
\text { Tpcpv3-Tpcpv2 }\end{array}$ \\
\hline
\end{tabular}


Table 6-1. Correlation Chart of Model Stratigraphy (Continued)

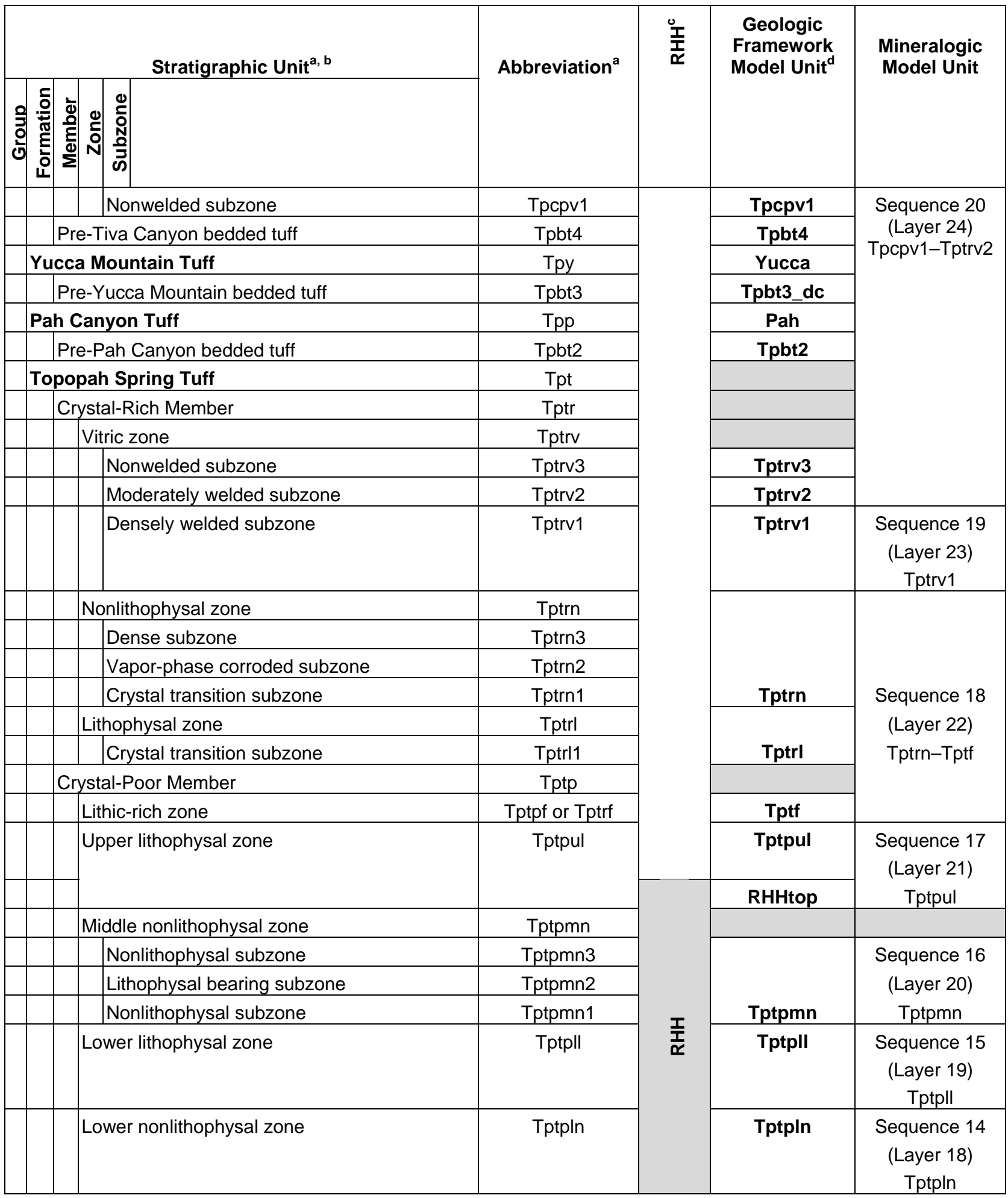


Table 6-1. Correlation Chart of Model Stratigraphy (Continued)

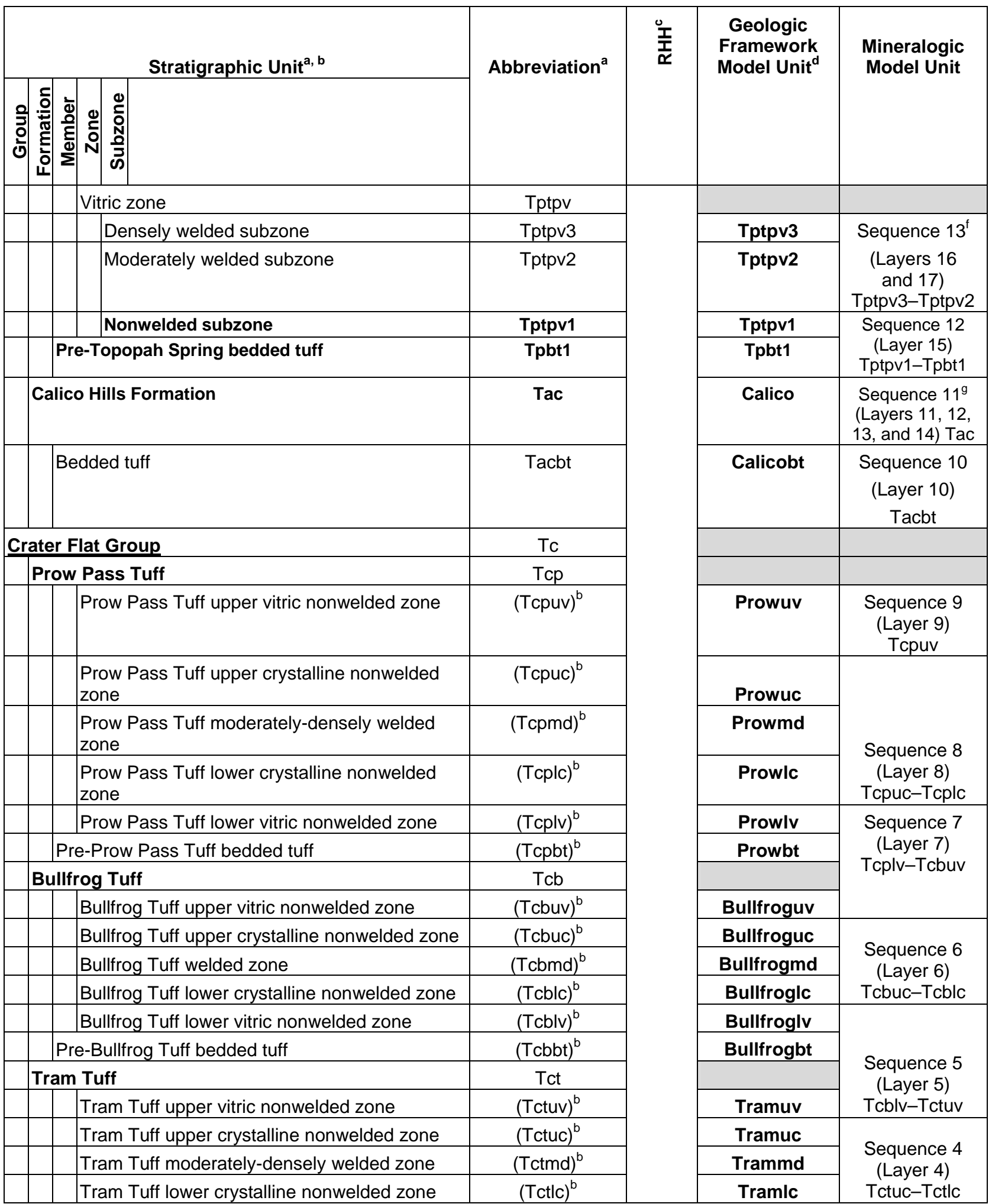


Table 6-1. Correlation Chart of Model Stratigraphy (Continued)

\begin{tabular}{|c|c|c|c|c|c|c|c|}
\hline \multicolumn{4}{|c|}{ Stratigraphic Unit ${ }^{\mathrm{a}, \mathrm{b}}$} & \multirow[t]{2}{*}{ Abbreviation $^{a}$} & \multirow[t]{2}{*}{ 茎 } & \multirow[t]{2}{*}{$\begin{array}{l}\text { Geologic } \\
\text { Framework } \\
\text { Model Unit }^{\mathrm{d}}\end{array}$} & \multirow[t]{2}{*}{$\begin{array}{l}\text { Mineralogic } \\
\text { Model Unit }\end{array}$} \\
\hline 원 & 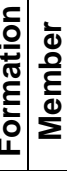 & 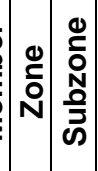 & & & & & \\
\hline & & \multicolumn{2}{|c|}{ Tram Tuff lower vitric nonwelded zone } & $(T c t l v)^{b}$ & & Tramlv & $\begin{array}{l}\text { Sequence } 3 \\
\text { (Layer 3) } \\
\text { Tctlv-Tctbt }\end{array}$ \\
\hline \multicolumn{4}{|c|}{ Pre-Tram Tuff bedded tuff } & $(T c t b t)^{b}$ & & Trambt & \\
\hline & \multicolumn{3}{|c|}{ Lava and flow breccia (informal) } & $\mathrm{TII}$ & & \multirow{14}{*}{ Tund } & \multirow{14}{*}{$\begin{array}{l}\text { Sequence } 2 \\
\text { (Layer 2) } \\
\quad \text { Tund }\end{array}$} \\
\hline \multicolumn{4}{|c|}{ Bedded tuff } & Tllbt & & & \\
\hline \multicolumn{4}{|c|}{ Lithic Ridge Tuff } & $\operatorname{Tr}$ & & & \\
\hline \multicolumn{4}{|c|}{ Bedded tuff } & Tlrbt & & & \\
\hline & \multirow{2}{*}{\multicolumn{3}{|c|}{$\begin{array}{l}\text { Lava and flow breccia (informal) } \\
\text { Bedded tuff }\end{array}$}} & TII2 & & & \\
\hline & & & & Tllbt & & & \\
\hline \multicolumn{4}{|c|}{ Lava and flow breccia (informal) } & TII3 & & & \\
\hline \multicolumn{4}{|c|}{ Bedded tuff } & Tll3bt & & & \\
\hline \multicolumn{4}{|c|}{ Older tuffs (informal) } & $\mathrm{Tt}$ & & & \\
\hline & \multirow{2}{*}{\multicolumn{3}{|c|}{\begin{tabular}{|l|l|} 
& Unit a (informal) \\
Unit b (informal)
\end{tabular}}} & Tta & & & \\
\hline & & & & Ttb & & & \\
\hline & \multicolumn{3}{|c|}{ Unit c (informal) } & Ttc & & & \\
\hline & \multicolumn{3}{|c|}{ Sedimentary rocks and calcified tuff (informal) } & Tca & & & \\
\hline & \multicolumn{3}{|c|}{ Tuff of Yucca Flat (informal) } & Tyf & & & \\
\hline \multicolumn{4}{|c|}{ Pre-Tertiary sedimentary rock } & & & \multirow{3}{*}{ Paleozoic } & \multirow{3}{*}{$\begin{array}{l}\text { Sequence } 1 \\
\text { (Layer 1) }^{\text {Paleozoic }^{h}}\end{array}$} \\
\hline \multicolumn{4}{|c|}{ Lone Mountain Dolomite } & SIm & & & \\
\hline \multicolumn{4}{|c|}{ Roberts Mountain Formation } & Srm & & & \\
\hline
\end{tabular}

Source: Mineralogic Model (MM3.0) Report (BSC 2004 [DIRS 170031], Table 1-1).

NOTE: In the RHH (Repository Host Horizon) column, shading indicates the RHH layers. Elsewhere, shaded rows indicate header lines for subdivided units. Sequence 1, Layer 1 is the Paleozoic layer (not included in this report).

${ }^{a}$ DTN: MO9510RIB00002.004 [DIRS 103801].

${ }^{b}$ For the purposes of the GFM, each formation in the Crater Flat Group was subdivided into six zones, based on the requirements of the users of the GFM. The subdivisions are upper vitric (uv), upper crystalline (uc), moderately to densely welded (md), lower crystalline (Ic), lower vitric (IV), and bedded tuff (bt) (Buesch and Spengler 1999 [DIRS 107905], pp. 62 to 63).

c Determination of Available Volume for Repository Siting (CRWMS M\&O 1997 [DIRS 100223], pp. 43 to 50).

'DTN: MO9901MWDGFM31.000 [DIRS 103769]. Although this DTN (MO9901MWDGFM31.000 [DIRS 103769]) was superseded by DTN: MO0012MWDGFM02.002 [DIRS 153777] when the GFM3.1 was updated to GFM2000, it provided the framework stratigraphy used in the development of version 3.0 of the mineralogical model, "MM3.0" (DTN: LA9908JC831321.001 [DIRS 113495]), which was used as input to this analysis. Development of the GFM2000 (DTN: MO0012MWDGFM02.002 [DIRS 153777]) was conducted after completion of the mineralogic model (DTN: LA9908JC831321.001 [DIRS 113495]). For the purpose of this analysis, there is no impact from using the superseded DTN in portraying the stratigraphy in Table 6-1.

e Correlated with the rhyolite of Comb Peak (Buesch et al. 1996 [DIRS 100106], Table 2).

f Sequence 13 (Tptpv3-Tptpv2) is subdivided into 2 layers of equal thickness.

${ }^{g}$ Sequence 11 (Tac) is subdivided into 4 layers of equal thickness.

${ }^{\mathrm{h}}$ Sequence 1 (Paleozoic) represents a lower bounding surface in the mineralogic model.

' Unit Tpc_un of the mineralogic model includes the following stratigraphic units: Qal, Qc, Tm, Tmr, Tp, Tpbt6, Tpki (informal), Tpbt5, Tpc, Tpcr, Tpcrv, Tpcrv3, Tpcrv2, Tpcrv1, Tpcrn, Tpcrn4, Tpcrn3, Tpcrn2, Tpcrn1, Tpcrl, Tpcrl1, Tpcp, Tpcpul, Tpcpul1, Tpcpmn, Tpcpmn3, Tpcpmn2, Tpcpmn1, Tpcpll, Tpcpllh, Tpcpln, Tpcplnh, and Tpcplnc. 
The mineral summation method, which is used in this report, uses mineral-abundance data and the heat capacity of the minerals to evaluate rock-grain heat capacity, using Equation 6-1. For the mineral summation method, the variables $x_{j}$ and $C_{p_{j}}$ are respectively defined as the abundance (weight fraction) and heat capacity of mineral $j ; n$ is the number of mineral components; and $C_{p, g}$ is the heat capacity of the rock grain. This method requires mineral-abundance and mineral-heat capacity data. As described in Section 4.1, the Mineralogic Model (MM3.0) Report (BSC 2004 [DIRS 170031]), DTN: LA9908JC831321.001 [DIRS 113495] provides a summary of the mineralogic abundance of the repository layers and also the surrounding layers. The mineral-abundance data have been derived from Yucca Mountain borehole samples. The locations of the boreholes and the sources of mineral-abundance data for each borehole are documented in the Mineralogic Model (MM3.0) Report (BSC 2004 [DIRS 170031], Figure 4-1 and Table 4-1). The locations of these boreholes are shown in Figure 6-1. These boreholes cover the area of repository as can be seen by comparing Figure 6-1 of this report to Figure 4-1 of the Multiscale Thermohydrologic Model (BSC 2004 [DIRS 169565]). The input data from DTN: LA9908JC831321.001 [DIRS 113495] provide good coverage of the area of interest for this analysis. Furthermore, heat capacity data for the mineral species or groups are also available (Section 4.1.2, Table 4-2).

The mineral summation method was selected (as the analytical technique for evaluating heat capacity in this analysis) because it is the only method for which all required data (mineral abundance and mineral-heat capacities) for the layers of interest were available. The accuracy of this method is adequate for the intended use of the heat capacity values. It should be noted that the results of numerical model simulations are not sensitive to the heat capacity of the different formations, which, in general, varies within a relatively small range (values around $1 \mathrm{~J} / \mathrm{g}-\mathrm{K}$ ). For example, as stated in the Multiscale Thermohydrologic Model report (BSC 2004 [DIRS 169565], Section 6.3.2) parametric uncertainty of the host-rock heat capacity has an insignificant influence on the multiscale thermal-hydrologic model's predictions of temperature and relative humidity.

Alternative methods, which require additional data for their use, are the oxide summation, and the fictive-oxide mineral-component methods. The oxide (major elements) summation method uses oxide-abundance data and the heat capacity of the oxides to evaluate the rock-grain heat capacity, $C_{p, g}$. This is described mathematically by Equation 6-1, which is based on Kopp's Law (Nimick and Connolly 1991 [DIRS 100690], p. 6).

$$
C_{p, g}=\sum_{j=1}^{j=n} x_{j} C_{p_{j}}
$$

where $x_{j}$ and $C_{p_{j}}$ are, respectively, the abundance (weight fraction) and heat capacity of oxide $j$; $n$ is the number of oxide components; and $C_{p, g}$ is the effective heat capacity of the rock grain. This method requires oxide data for the Yucca Mountain stratigraphic units. At present, major-element data are sparse for non-repository units (DTN: GS000308313211.001 [DIRS 162015]). Therefore, due to the lack of appropriate oxide (major element) data for the layers surrounding the repository units, this method was not selected. 
The fictive-oxide mineral-component method proposed by Robinson and Haas (1983 [DIRS 107148], pp. 548 to 551) is another method for estimating the heat capacity of rock grains. This method requires detailed information on the composition and structure of mineral species, and very accurate weight-fraction measurements. This method was not selected due to the unavailability of these input data.

\subsection{HEAT CAPACITY METHODOLOGY}

The mineral summation method was used to estimate the heat capacity of mineral composites in each stratigraphic unit (layer and sequence) defined by the Mineralogic Model (MM3.0) Report (BSC 2004 [DIRS 170031], Table 1-1). The summation expressed by Equation 6-1 is based on Kopp's law (Nimick and Connolly 1991 [DIRS 100690], p. 6). According to Kopp's law, the heat capacity of mineral component $j$ in the composite is the same as that of mineral $j$ on its own (Berryman 1995 [DIRS 159696], p. 218); this an acceptable method for estimating heat capacities of most rocks, including those of interest in the Yucca Mountain Project (Nimick and Connolly 1991 [DIRS 100690]).

\subsection{MINERAL ABUNDANCE}

Output of the Mineralogic Model (MM3.0) Report (BSC 2004 [DIRS 170031], Section 6.2.3), found in DTN: LA9908JC831321.001 [DIRS 113495], provides the mineral abundances of ten mineral groups. The mineral groups are:

1. Smectite and illite,

2. Sorptive zeolites (clinoptilolite, heulandite, mordenite, chabazite, erionite, and stellerite),

3. Tridymite,

4. Cristobalite and opal-CT,

5. Quartz,

6. Feldspar,

7. Volcanic glass,

8. Nonsorptive zeolite (analcime),

9. Mica, and

10. Calcite. 


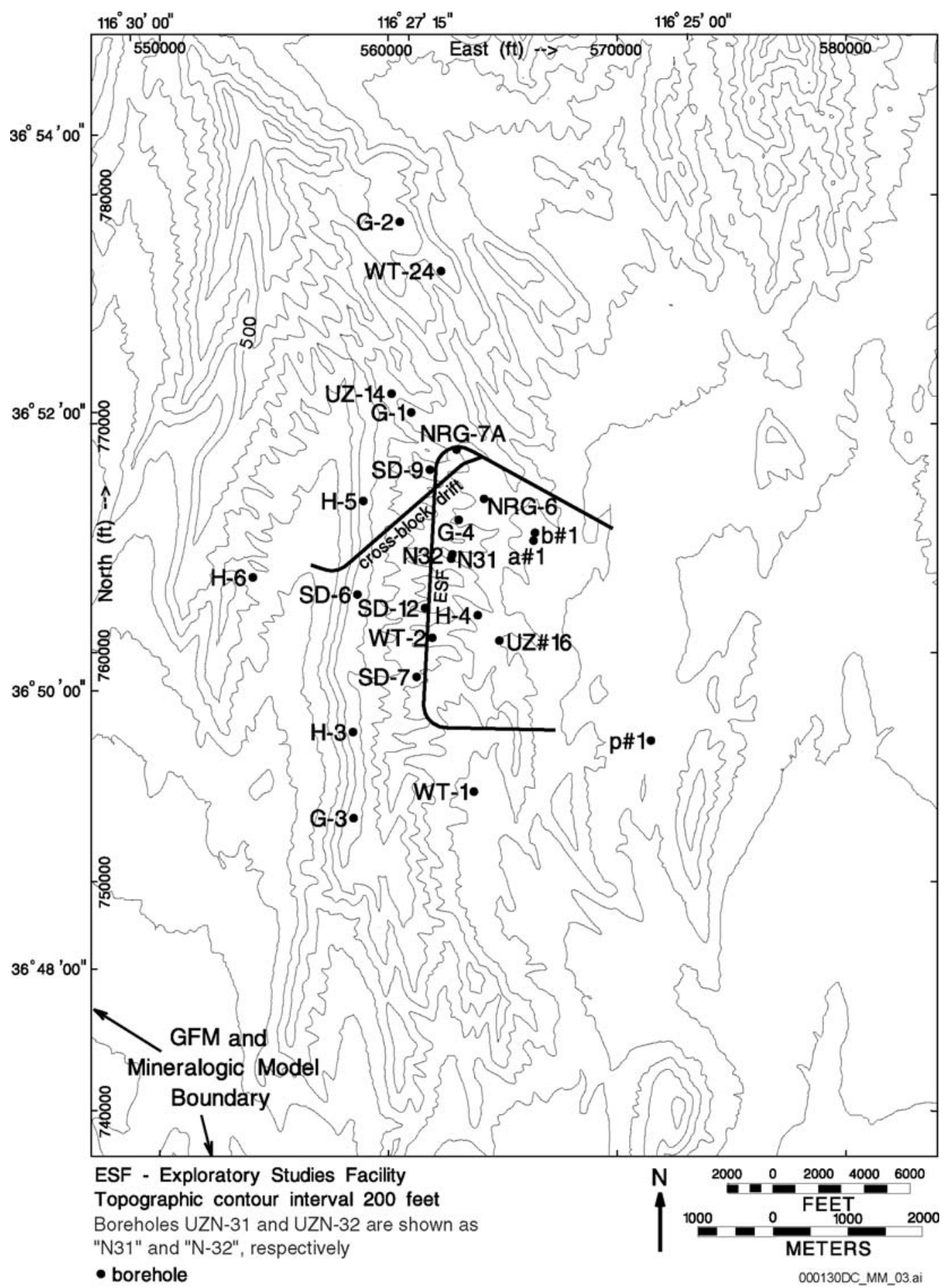

Source: Mineralogic Model (MM3.0) Report (BSC 2004 [DIRS 170031], Figure 4-1).

Figure 6-1. Locations of Boreholes Used in the Mineralogic Model 
As shown in Table 6-1, the stratigraphy in the mineralogic model has 22 sequences and 26 layers. For 25 of the 26 layers, EARTHVISION was used to calculate the average and standard deviation of the mineral abundance for the ten mineral groups; Sequence-1 (Layer 1 of the mineralogic model), the Paleozoic, was excluded from this analysis because the required mineralogic abundance data were not available from DTN: LA9908JC831321.001 [DIRS 113495]. Excluding the Paleozoic from the analysis has no effect on other models, because heat capacity values for this formation are not needed; this layer is more than one thousand meters below the repository horizon, and is not included in any thermal or thermal-hydrologic models. Units Tpcpv1, Tpbt4, Tpy, Tpbt3, Tpp, Tpbt2, Tptrv3, and Tptrv2 (Sequence 20 of the mineralogic model) are included in Table 6-2 as a single unit, the PTn. The results of these EARTHVISION calculations are provided in Table 6-2. In general, the sum of the average mineral-abundances for a layer does not exactly equal 100 percent. The abundance values in Table 6-2 can be normalized by dividing each average mineral-abundance by the sum of the average abundances. The values in Table 6-2 are not normalized, so the sum of the abundances does not equal 1.0. The normalization is performed in the output DTN: SN0307T0510902.003. This step converted the weight-percent abundance values in Table 6-2 to the weight-fractions abundances required by Equation 6-1. This normalization also ensured that the sum of the weight-fraction abundances for each layer equals one.

When examining Table 6-2, the significant minerals (in terms of abundance) are feldspars, sorptive zeolites, silica polymorphs (i.e., tridymite, cristobalite, opal-CT, and quartz), and volcanic glasses. Feldspars are found in all layers, and are the most abundant minerals, except in the Calico Hills Formation and the layer just above it (sorptive zeolites are significant in the Calico Hills Formation and the layers immediately above and below it). The most abundant sorptive zeolites are clinoptilolite and mordenite (BSC 2004 [DIRS 170031], p. 6-21). Heulandite is a fairly common mineral, but its XRD abundance was combined with clinoptilolite because the two minerals have the same crystal structure (BSC 2004 [DIRS 170031], p. 6-21). Silica polymorphs can be found in all layers in significant abundances. The primary silica polymorphs are cristobalite and quartz; tridymite abundances are generally much smaller. In general, tridymite has higher abundance in the layers within and above the Calico Hills Formation. In contrast, quartz is the dominant silica polymorph in layers below the Calico Hills Formation. Volcanic glass is abundant in the nonwelded layers (bedded tuffs). The nonwelded layers are the PTn and surrounding layers, along with the Calico Hills Formation and surrounding layers.

In terms of their abundances, the remaining mineral groups (smectite, analcime, mica, and calcite) are much less significant: most do not exceed 10 percent. The only exception is smectite, which exceeds 10 percent in a few layers. In general, analcime, mica, and calcite have very low abundances (less than 2 percent); the only exception is analcime, which exceeds 5 percent in the lowest layer that was considered (the Tund).

Layers of the Calico Hills Formation are characterized as vitric or zeolitic (Flint 1998 [DIRS 100033], p. 29). This bimodal composition also characterizes the layers adjacent to the Calico Hills Formation (Tptpv2, Tptpv1-Tpbt1, and Tacbt). The compositional character of these layers is illustrated in the Mineralogic Model (MM3.0) Report (BSC 2004 [DIRS 170031], Figures 6-5 to 6-16, 6-19, and 6-20). 
Table 6-2. Mineral Abundance of the Ten Mineral Groups in the Mineralogic Model

\begin{tabular}{|c|c|c|c|c|c|c|c|c|c|c|}
\hline \multirow[b]{3}{*}{ Unit } & \multicolumn{10}{|c|}{ Mineral Abundance ${ }^{a}$ (expressed in weight percent) } \\
\hline & \multicolumn{2}{|c|}{ Smectite-Illite } & \multicolumn{2}{|c|}{ Sorptive Zeolite } & \multicolumn{2}{|c|}{ Tridymite } & \multicolumn{2}{|c|}{ Cristobalite-Opal CT } & \multicolumn{2}{|c|}{ Quartz } \\
\hline & Average & $\begin{array}{l}\text { Standard } \\
\text { Deviation }\end{array}$ & Average & $\begin{array}{l}\text { Standard } \\
\text { Deviation }\end{array}$ & Average & $\begin{array}{l}\text { Standard } \\
\text { Deviation }\end{array}$ & Average & $\begin{array}{l}\text { Standard } \\
\text { Deviation }\end{array}$ & Average & $\begin{array}{l}\text { Standard } \\
\text { Deviation }\end{array}$ \\
\hline Tpc_un & 1.20 & 0.61 & 0.15 & 0.26 & 5.12 & 3.34 & 27.59 & 5.26 & 0.93 & 0.37 \\
\hline Tpсpv3-Tpсpv2 & 12.66 & 4.77 & 0.00 & 0.00 & 0.00 & 0.00 & 12.37 & 1.73 & 0.07 & 0.14 \\
\hline $\mathrm{PTn}^{\mathrm{b}}$ & 12.13 & 4.93 & 1.68 & 2.51 & 2.10 & 2.09 & 8.07 & 5.51 & 1.30 & 0.69 \\
\hline Tptrv1 & 0.48 & 0.33 & 0.01 & 0.01 & 0.08 & 0.10 & 2.01 & 1.49 & 0.11 & 0.12 \\
\hline Tptrn-Tptrl-Tptf & 1.16 & 1.48 & 0.12 & 0.17 & 11.20 & 2.61 & 12.73 & 5.69 & 1.53 & 2.44 \\
\hline Tptpul & 2.50 & 1.37 & 0.06 & 0.14 & 6.05 & 2.93 & 21.58 & 1.97 & 6.94 & 4.88 \\
\hline Tptpmn & 2.03 & 0.62 & 0.01 & 0.02 & 2.38 & 1.24 & 18.46 & 8.44 & 13.52 & 8.94 \\
\hline Tptpll & 2.48 & 2.13 & 0.23 & 0.28 & 2.09 & 1.33 & 14.54 & 6.75 & 19.94 & 5.93 \\
\hline Tptpln & 1.13 & 1.07 & 0.59 & 0.60 & 0.89 & 0.96 & 12.90 & 5.20 & 21.46 & 4.22 \\
\hline Tptpv3 & 12.74 & 8.03 & 8.67 & 10.52 & 0.00 & 0.00 & 14.01 & 4.94 & 2.23 & 1.63 \\
\hline Tptpv2 & 5.14 & 4.59 & 9.34 & 9.05 & 0.00 & 0.00 & 10.38 & 3.17 & 2.94 & 1.32 \\
\hline Tptpv1-Tpbt1 & 2.46 & 2.69 & 40.08 & 24.57 & 0.07 & 0.21 & 13.36 & 6.07 & 2.59 & 1.41 \\
\hline $\operatorname{Tac}^{\mathrm{C}}$ & 1.16 & 0.53 & 39.11 & 27.32 & 0.02 & 0.08 & 13.98 & 6.02 & 5.50 & 2.20 \\
\hline $\operatorname{Tac}^{\mathrm{C}}$ & 1.57 & 0.89 & 38.69 & 22.36 & 0.00 & 0.00 & 14.06 & 6.09 & 5.31 & 1.78 \\
\hline $\operatorname{Tac}^{\mathrm{C}}$ & 1.40 & 0.90 & 40.56 & 21.63 & 0.00 & 0.00 & 14.22 & 6.19 & 5.43 & 2.46 \\
\hline $\operatorname{Tac1}^{\mathrm{c}}$ & 0.78 & 0.69 & 40.27 & 20.25 & 0.00 & 0.00 & 11.75 & 4.73 & 7.89 & 6.03 \\
\hline Tacbt & 5.11 & 3.18 & 22.39 & 11.76 & 0.00 & 0.00 & 5.01 & 3.76 & 16.69 & 7.16 \\
\hline Tcpuv & 3.94 & 1.50 & 31.10 & 15.46 & 0.21 & 0.48 & 12.82 & 9.21 & 8.82 & 8.18 \\
\hline Tcpuc-Tcpmd-Tcplc & 2.16 & 1.23 & 0.46 & 0.54 & 1.06 & 1.63 & 7.65 & 5.33 & 25.76 & 9.54 \\
\hline Tcplv-Tcpbt-Tcbuv & 4.87 & 4.28 & 47.64 & 12.26 & 0.06 & 0.14 & 9.54 & 2.94 & 8.83 & 6.18 \\
\hline Tcbuc-Tcbmd-Tcblc & 2.01 & 1.30 & 0.22 & 0.37 & 0.20 & 0.32 & 4.72 & 4.47 & 28.16 & 6.49 \\
\hline Tcblv-Tcbbt-Tctuv & 8.53 & 4.47 & 29.27 & 13.71 & 0.00 & 0.00 & 1.93 & 2.06 & 19.05 & 9.21 \\
\hline Tctuc-Tctmd-Tctlc & 2.76 & 2.30 & 0.60 & 0.92 & 0.00 & 0.00 & 3.99 & 5.24 & 28.66 & 7.44 \\
\hline Tctlv-Tctbt & 2.76 & 2.30 & 0.60 & 0.92 & 0.00 & 0.00 & 3.99 & 5.24 & 28.66 & 7.44 \\
\hline Tund & 13.39 & 5.77 & 1.81 & 2.36 & 0.00 & 0.00 & 0.85 & 2.13 & 30.00 & 6.99 \\
\hline
\end{tabular}


Table 6-2. Mineral Abundance of the Ten Mineral Groups in the Mineralogic Model (Continued)

\begin{tabular}{|c|c|c|c|c|c|c|c|c|c|c|}
\hline \multirow[b]{3}{*}{ Unit } & \multicolumn{10}{|c|}{ Mineral Abundance ${ }^{a}$ (expressed in weight percent) } \\
\hline & \multicolumn{2}{|c|}{ Feldspars } & \multicolumn{2}{|c|}{ Volcanic Glass } & \multicolumn{2}{|c|}{ Analcime } & \multicolumn{2}{|c|}{ Mica } & \multicolumn{2}{|c|}{ Calcite } \\
\hline & Average & $\begin{array}{l}\text { Standard } \\
\text { Deviation }\end{array}$ & Average & $\begin{array}{l}\text { Standard } \\
\text { Deviation }\end{array}$ & Average & $\begin{array}{l}\text { Standard } \\
\text { Deviation }\end{array}$ & Average & $\begin{array}{l}\text { Standard } \\
\text { Deviation }\end{array}$ & Average & $\begin{array}{l}\text { Standard } \\
\text { Deviation }\end{array}$ \\
\hline Tpc_un & 62.45 & 8.24 & 8.71 & 0.24 & 0.00 & 0.00 & 0.47 & 0.90 & 0.44 & 0.55 \\
\hline Tpcpv3-Tpcpv2 & 28.96 & 7.00 & 44.38 & 4.71 & 0.00 & 0.00 & 0.00 & 0.00 & 2.24 & 2.52 \\
\hline $\mathrm{PTn}^{\mathrm{b}}$ & 24.81 & 13.00 & 47.11 & 18.33 & 0.00 & 0.00 & 0.94 & 0.50 & 0.85 & 1.33 \\
\hline Tptrv1 & 21.17 & 4.51 & 71.72 & 7.58 & 0.00 & 0.00 & 1.19 & 0.13 & 1.64 & 1.91 \\
\hline Tptrn-Tptrl-Tptf & 68.82 & 8.92 & 0.07 & 0.13 & 0.00 & 0.00 & 1.24 & 0.55 & 0.51 & 0.40 \\
\hline Tptpul & 61.38 & 7.87 & 0.00 & 0.00 & 0.00 & 0.00 & 0.31 & 0.31 & 0.41 & 0.95 \\
\hline Tptpmn & 62.35 & 3.61 & 0.00 & 0.00 & 0.00 & 0.00 & 0.41 & 0.35 & 0.05 & 0.09 \\
\hline Tptpll & 59.36 & 6.76 & 0.00 & 0.00 & 0.00 & 0.00 & 0.21 & 0.11 & 0.07 & 0.10 \\
\hline Tptpln & 61.87 & 4.09 & 0.00 & 0.00 & 0.00 & 0.00 & 0.37 & 0.23 & 0.01 & 0.02 \\
\hline Tptpv3 & 16.50 & 9.75 & 46.62 & 15.86 & 0.00 & 0.00 & 0.26 & 0.42 & 0.02 & 0.07 \\
\hline Tptpv2 & 16.08 & 9.68 & 56.23 & 9.66 & 0.00 & 0.00 & 0.28 & 0.20 & 0.02 & 0.03 \\
\hline Tptpv1-Tpbt1 & 14.55 & 6.17 & 27.62 & 27.90 & 0.00 & 0.00 & 0.09 & 0.10 & 0.06 & 0.17 \\
\hline Tac4 $^{\mathrm{C}}$ & 22.48 & 10.13 & 20.80 & 24.86 & 0.00 & 0.00 & 0.40 & 0.32 & 0.00 & 0.00 \\
\hline $\operatorname{Tac}^{\mathrm{c}}$ & 23.17 & 10.02 & 18.78 & 24.16 & 0.00 & 0.01 & 0.74 & 0.69 & 0.00 & 0.00 \\
\hline $\operatorname{Tac}^{\mathrm{c}}$ & 22.26 & 8.25 & 17.83 & 23.37 & 0.00 & 0.01 & 0.84 & 0.84 & 0.00 & 0.01 \\
\hline Tac1 $^{\mathrm{c}}$ & 21.79 & 5.07 & 18.29 & 24.16 & 0.00 & 0.00 & 1.36 & 1.94 & 0.01 & 0.02 \\
\hline Tacbt & 33.36 & 5.20 & 14.49 & 16.19 & 0.00 & 0.00 & 2.01 & 1.33 & 0.40 & 0.56 \\
\hline Tcpuv & 32.84 & 9.93 & 12.41 & 14.58 & 0.00 & 0.00 & 0.24 & 0.42 & 0.07 & 0.18 \\
\hline Tcpuc-Tcpmd-Tcplc ${ }^{\mathrm{e}}$ & 62.08 & 4.56 & 0.24 & 0.58 & 0.00 & 0.00 & 0.69 & 0.77 & 0.06 & 0.11 \\
\hline Tcplv-Tcpbt-Tcbuv $^{f}$ & 25.37 & 3.46 & 2.67 & 3.69 & 2.29 & 4.08 & 0.42 & 0.37 & 0.00 & 0.00 \\
\hline Tcbuc-Tcbmd-Tcblc ${ }^{g}$ & 60.45 & 5.13 & 0.17 & 0.28 & 0.00 & 0.00 & 3.04 & 2.22 & 0.16 & 0.26 \\
\hline Tcblv-Tcbbt-Tctuv ${ }^{\mathrm{h}}$ & 34.90 & 5.66 & 0.00 & 0.00 & 4.45 & 4.41 & 3.06 & 1.49 & 0.29 & 0.53 \\
\hline Tctuc-Tctmd-Tctlc ${ }^{i}$ & 60.46 & 4.83 & 0.00 & 0.00 & 0.03 & 0.04 & 3.05 & 1.81 & 0.30 & 0.46 \\
\hline
\end{tabular}


Table 6-2. Mineral Abundance of the Ten Mineral Groups in the Mineralogic Model (Continued)

\begin{tabular}{|c|c|c|c|c|c|c|c|c|c|c|}
\hline \multirow[b]{3}{*}{ Unit } & \multicolumn{10}{|c|}{ Mineral Abundance ${ }^{a}$ (expressed in weight percent) } \\
\hline & \multicolumn{2}{|c|}{ Feldspars } & \multicolumn{2}{|c|}{ Volcanic Glass } & \multicolumn{2}{|c|}{ Analcime } & \multicolumn{2}{|c|}{ Mica } & \multicolumn{2}{|c|}{ Calcite } \\
\hline & Average & $\begin{array}{l}\text { Standard } \\
\text { Deviation }\end{array}$ & Average & $\begin{array}{l}\text { Standard } \\
\text { Deviation }\end{array}$ & Average & $\begin{array}{l}\text { Standard } \\
\text { Deviation }\end{array}$ & Average & $\begin{array}{l}\text { Standard } \\
\text { Deviation }\end{array}$ & Average & $\begin{array}{l}\text { Standard } \\
\text { Deviation }\end{array}$ \\
\hline Tctlv-Tctbt & 60.46 & 4.83 & 0.00 & 0.00 & 0.03 & 0.04 & 3.05 & 1.81 & 0.30 & 0.46 \\
\hline Tund & 38.69 & 4.65 & 0.38 & 0.97 & 6.00 & 4.07 & 5.04 & 3.84 & 3.46 & 2.10 \\
\hline
\end{tabular}

Source DTN: LA9908JC831321.001 [DIRS 113495].

a This table was developed by reformatting (Lum 2004 [DIRS 172044]) the mineral abundance values obtained with EARTHVISION.

b PTn = Tpcpv1, Tpbt4, Tpy, Tpbt3, Tpp, Tpbt2, Tptrv3, Tptrv2.

c Tac4: Sequence 11, Layer 14; Tac3: Sequence 11, Layer 13; Tac2: Sequence 11, Layer 12; Tac1: Sequence 11, Layer 11;

d Average mineral abundance is not normalized and may not sum to 100 percent.

e Tcpuc-Tcpmd-Tcplc is the same as unit Tcpuc-Tcplc in the mineralogic model. The mineralogic model name was expanded to indicate that this unit also includes the stratigraphic unit Tcpmd.

${ }^{f}$ Tcplv-Tcpbt-Tcbuv is the same as unit Tcplv-Tcbuv in the mineralogic model. The mineralogic model name was expanded to indicate that this unit also includes the stratigraphic unit Tcpbt.

g Tcbuc-Tcbmd-Tcblc is the same as unit Tcbuc-Tcblc in the mineralogic model. The mineralogic model name was expanded to indicate that this unit also includes the stratigraphic unit Tcbmd.

a ${ }^{\mathrm{h}}$ Tcblv-Tcbbt-Tctuv is the same as unit Tcblv-Tctuv in the mineralogic model. The mineralogic model name was expanded to indicate that this unit also

includes the stratigraphic unit Tcbbt.

i Tctuc-Tctmd-Tctlc is the same as unit Tctuc-Tctlc in the mineralogic model. The mineralogic model name was expanded to indicate that this unit also includes the stratigraphic unit Tctmd.

j Tpc_un is the same as unit Alluvium-Tpc_un in the mineralogic model. 
To determine the mineralogic composition of the vitric and zeolitic zones of the layers, the boundary between the zones needs to be established. To determine the location of the boundary, histograms of zeolite abundance for the layers were plotted. Figures 6-2 to 6-8 show the histograms of sorptive zeolite abundance for the four Calico Hills Formation layers (Tac1, Tac2, Tac3, and Tac4, corresponding to mineralogic model layers 11,12, 13, and 14, respectively, in Table 6-1) and adjacent layers (Tptpv2, Tptpv1-Tpbt1, and Tacbt), with zeolite abundance (expressed as a percent) plotted versus frequency (expressed as a percent). All histogram plots display a bimodal distribution of low zeolite abundance and high zeolite abundance. Figures 6-2 to 6-8 were produced with EARTHVISION using as input data from DTN: LA9908JC831321.001 [DIRS 113495].

Based on this bimodal distribution in zeolite abundance, shown in Figures 6-2 through 6-8, the criterion selected to distinguish between the vitric and zeolitic zones in the layers was 15 percent zeolitic abundance. This criterion was selected based on inspection of the shape of the distributions shown in Figures 6-2 to 6-8. In all these figures, the end of the first part of the frequency distribution is at about 15 percent. Regions with at least 15 percent zeolite abundance were characterized as zeolitic; regions with less than 15 percent zeolite abundance were characterized as vitric. EARTHVISION was then used to calculate the mineral abundance for the 10 mineral groups in the vitric and zeolitic zones of the layers. The mineral abundance of the zeolitic zones and vitric zones are presented in Table 6-3 and Table 6-4, respectively. 


\section{Frequency (\%)}

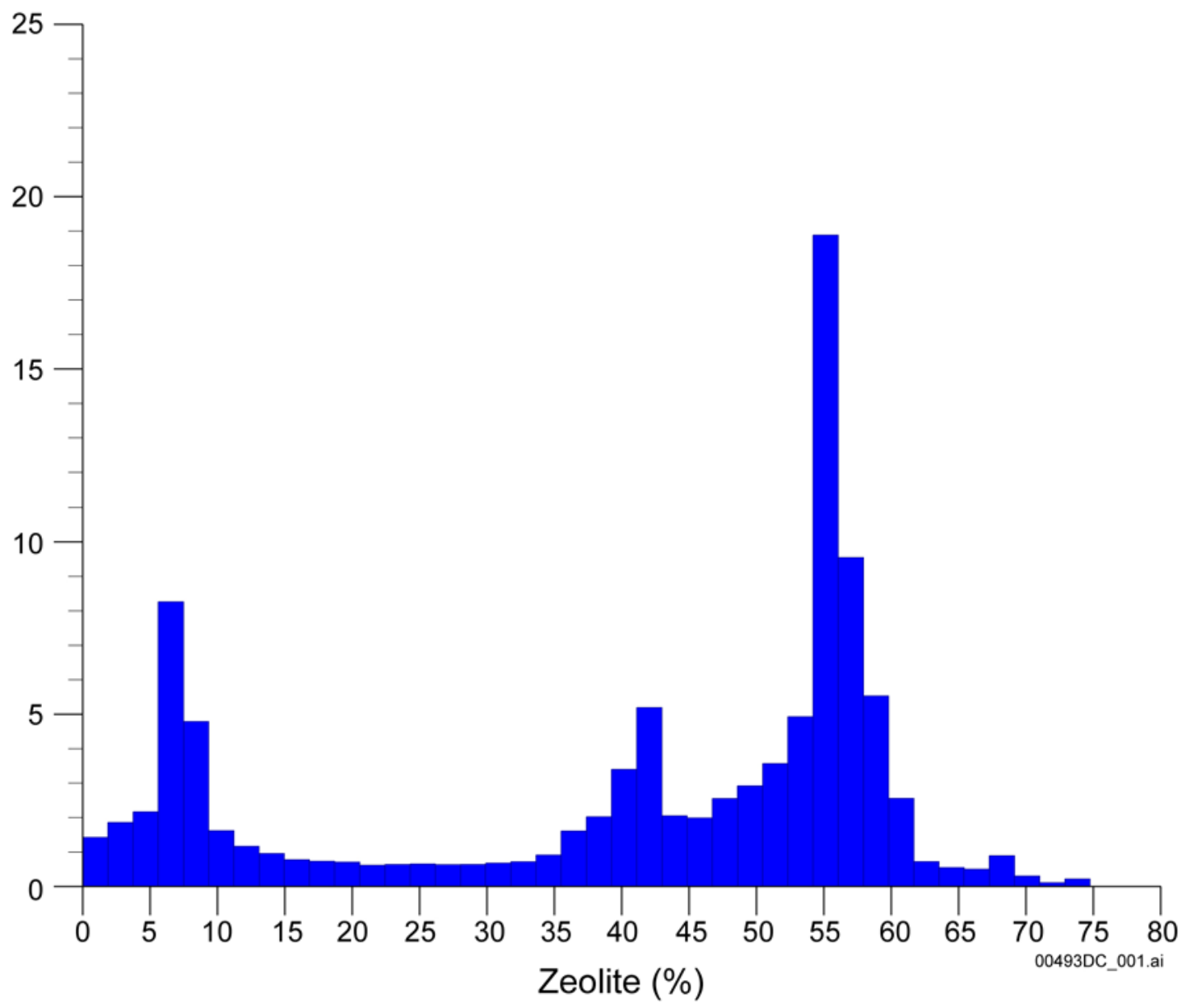

DTN: LA9908JC831321.001 [DIRS 113495].

Figure 6-2. Zeolite Abundance Versus Frequency: Tac1 


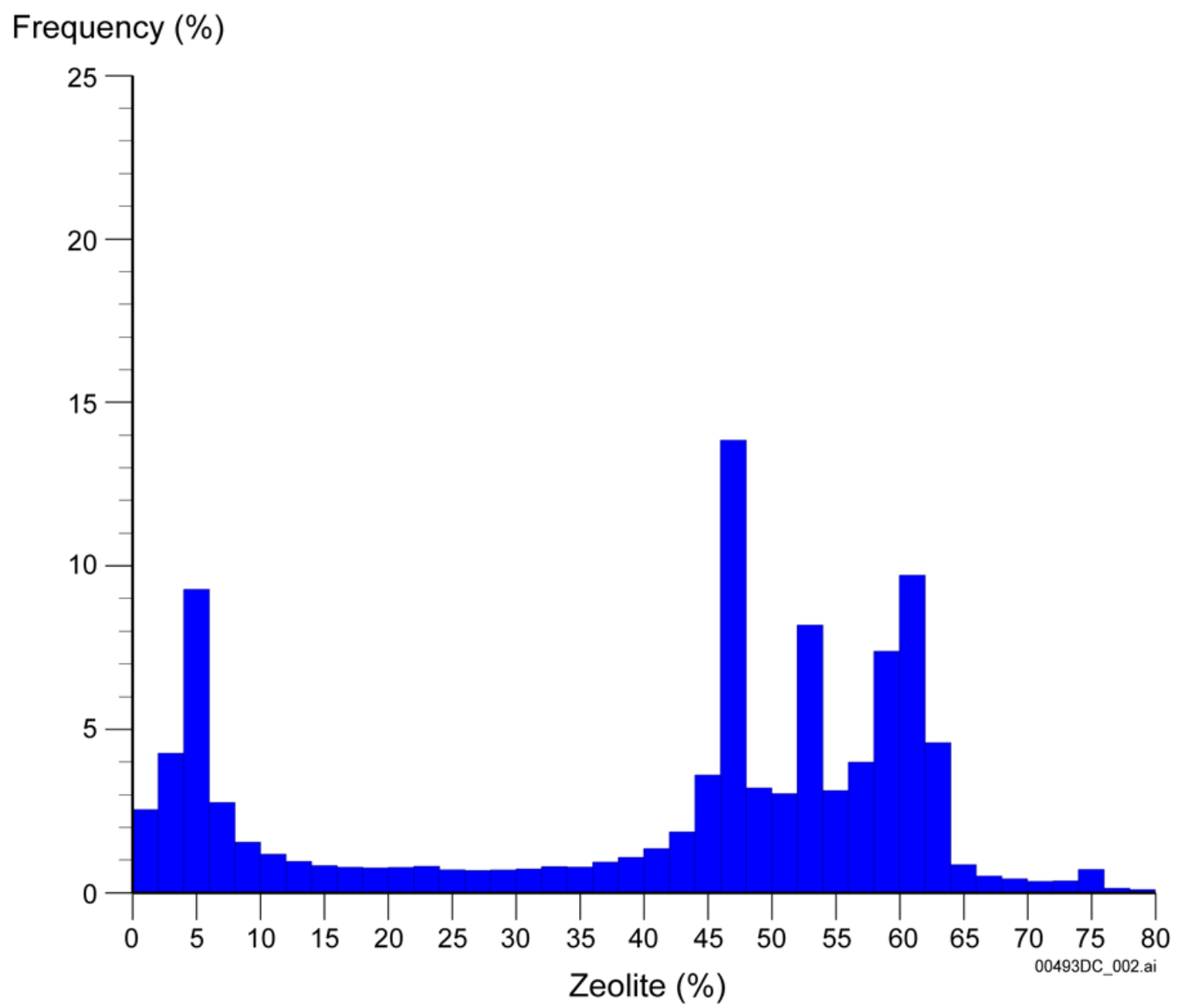

DTN: LA9908JC831321.001 [DIRS 113495].

Figure 6-3. Zeolite Abundance Versus Frequency: Tac2 


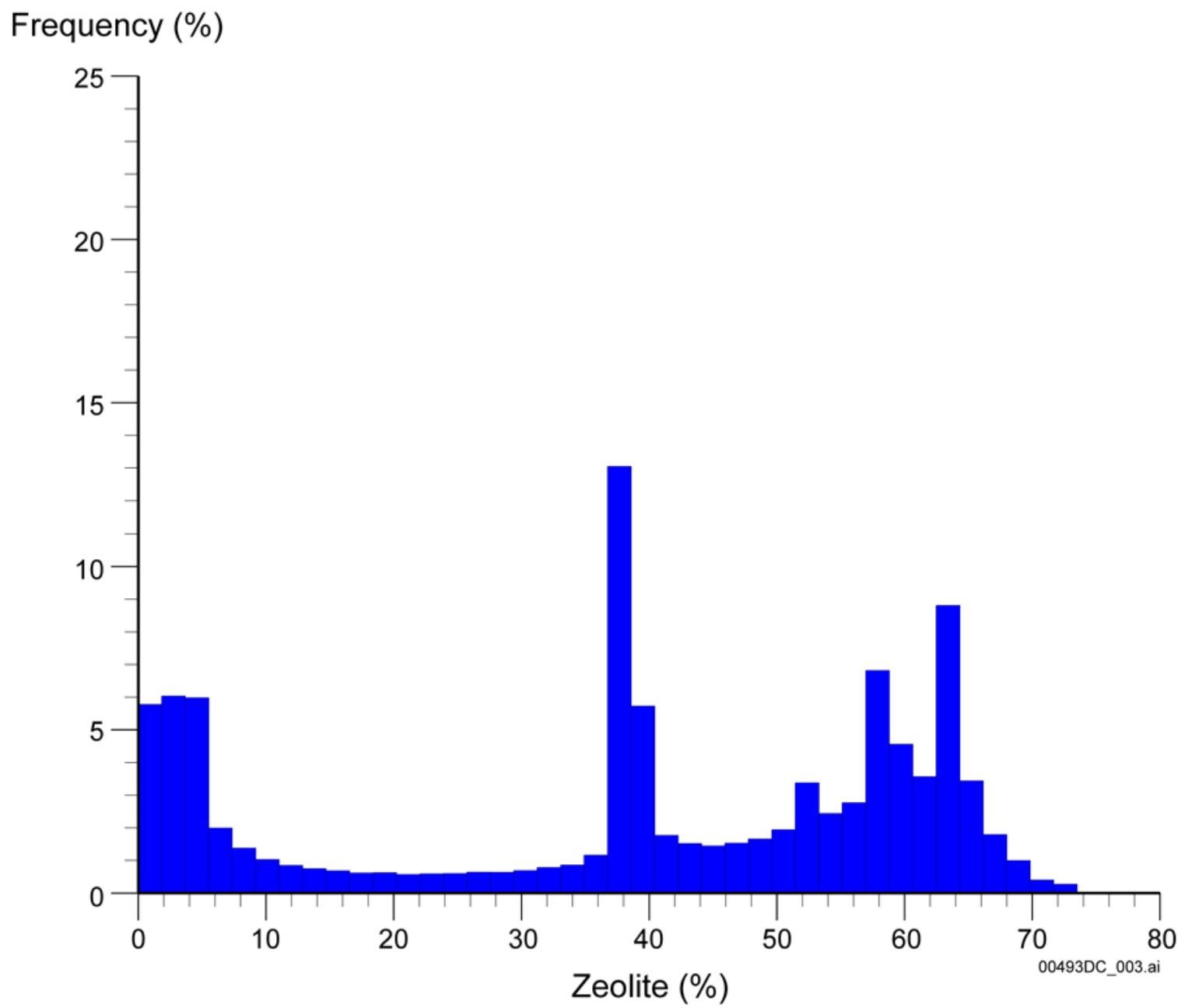

DTN: LA9908JC831321.001 [DIRS 113495].

Figure 6-4. Zeolite Abundance Versus Frequency: Tac3 


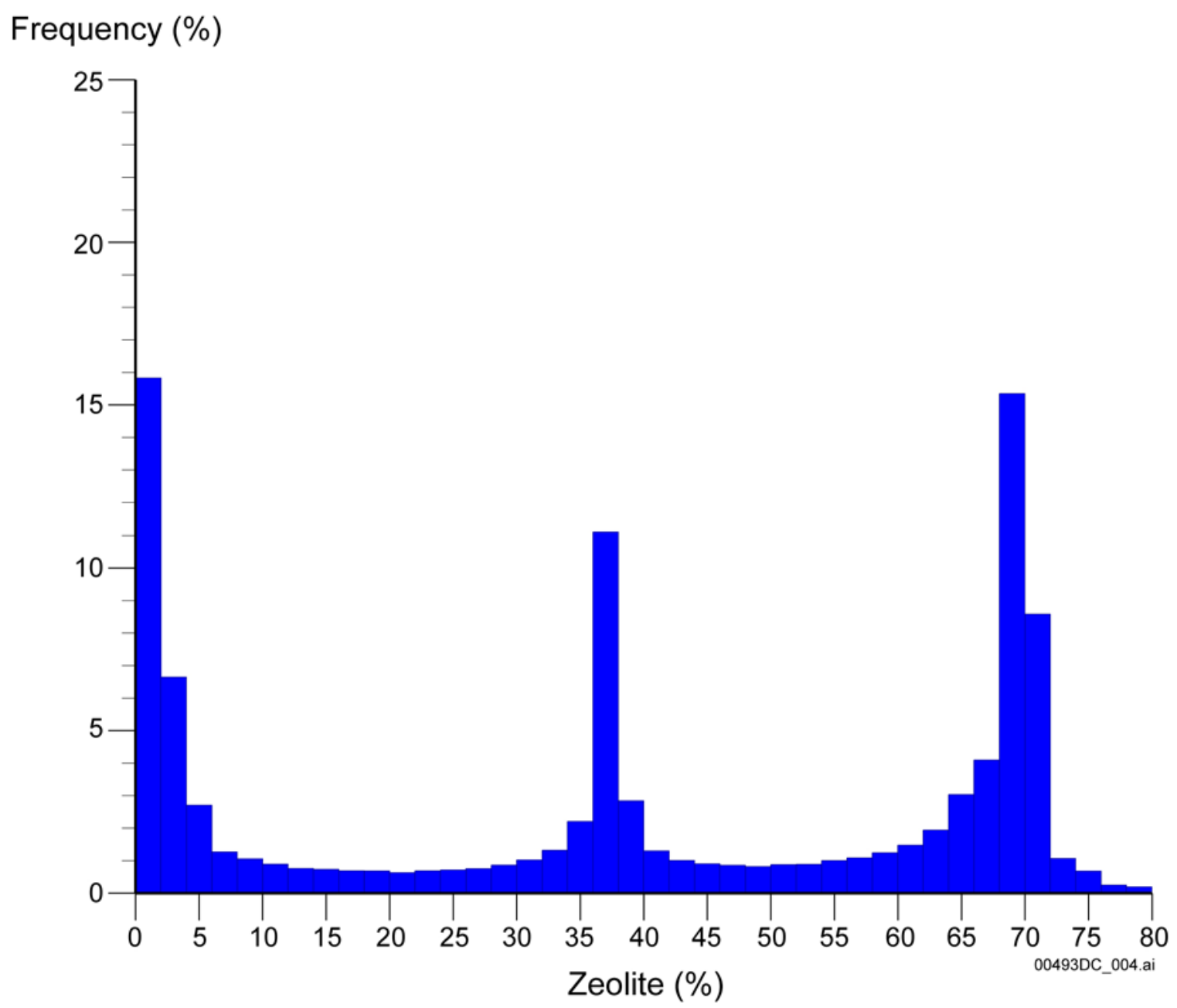

DTN: LA9908JC831321.001 [DIRS 113495].

Figure 6-5. Zeolite Abundance Versus Frequency: Tac4 


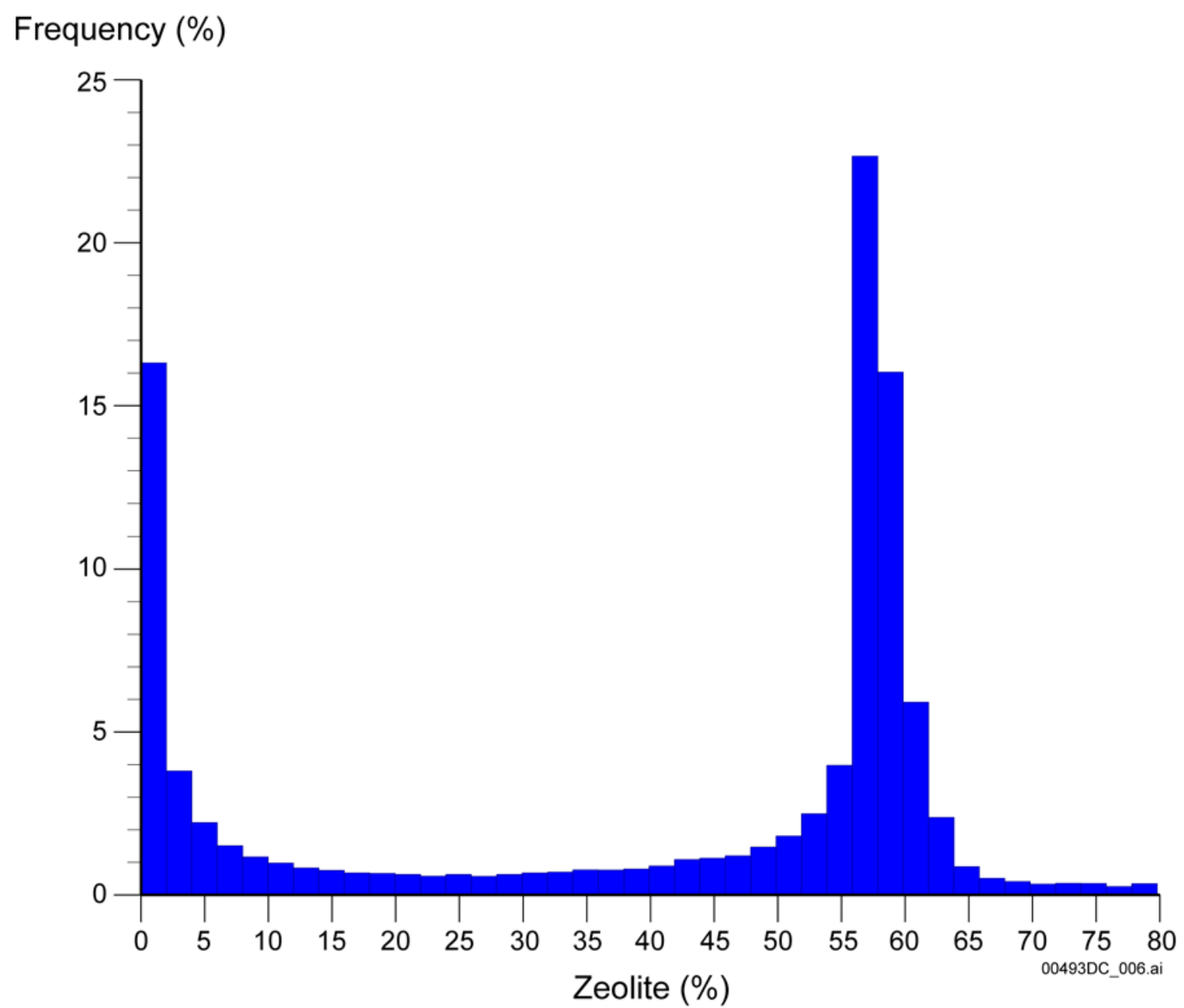

DTN: LA9908JC831321.001 [DIRS 113495].

Figure 6-6. Zeolite Abundance Versus Frequency: Tptpv1 - Tpbt1 


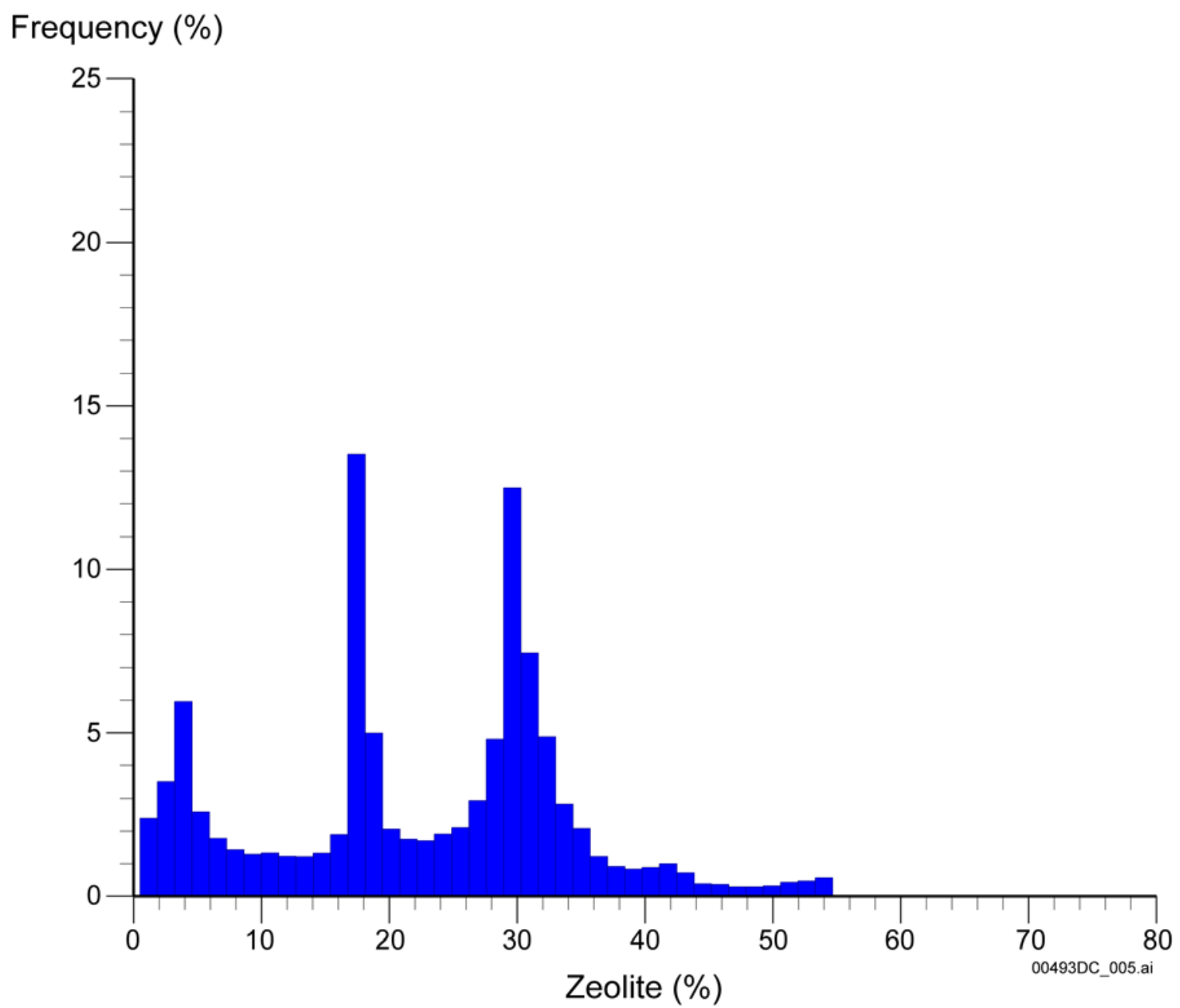

DTN: LA9908JC831321.001 [DIRS 113495].

Figure 6-7. Zeolite Abundance Versus Frequency: Tacbt 


\section{Frequency (\%)}

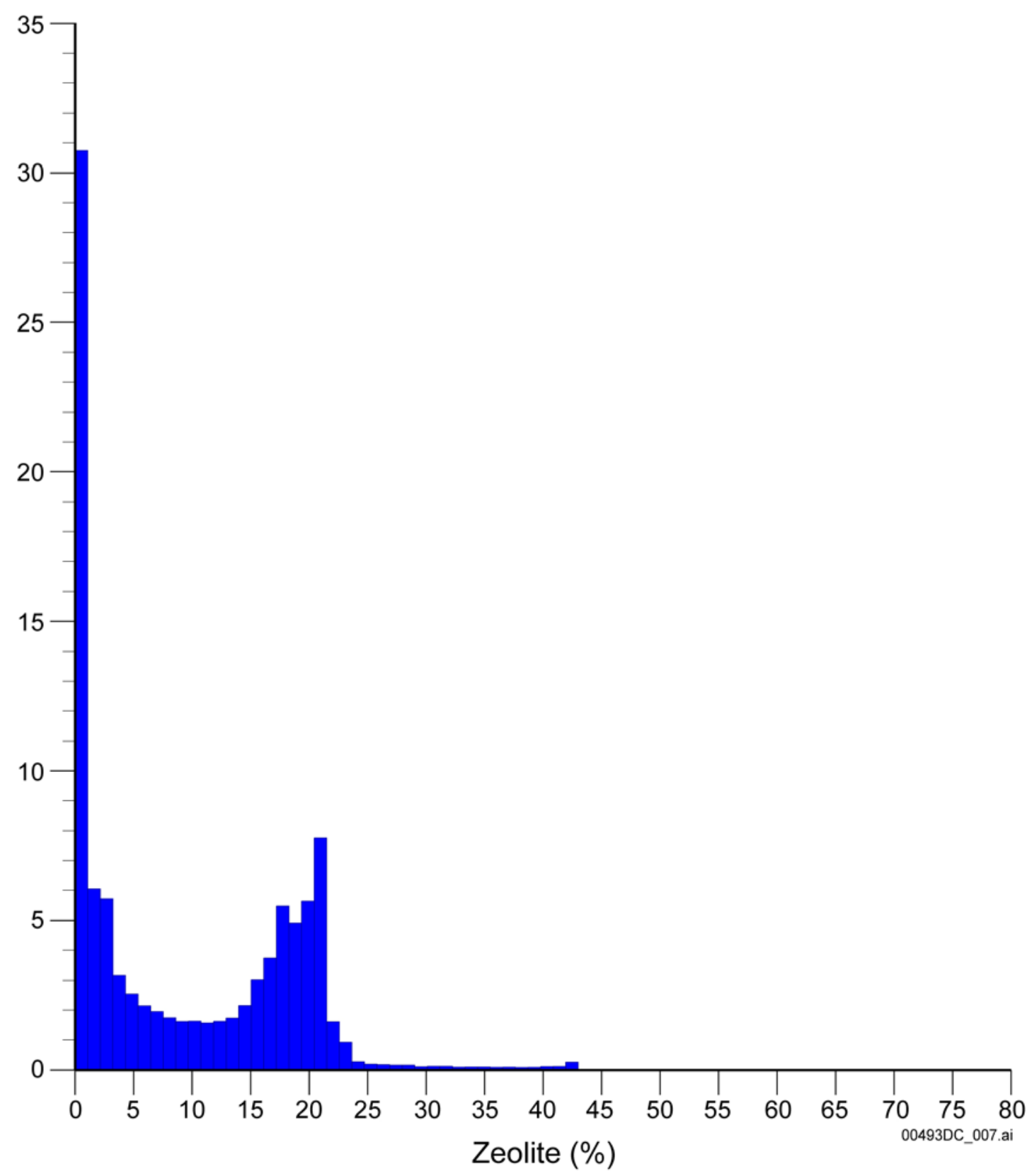

DTN: LA9908JC831321.001 [DIRS 113495].

Figure 6-8. Zeolite Abundance Versus Frequency: Tptpv2 
Table 6-3. Mineral Abundance of the Ten Mineral Groups in the Vitric Zones for Layers of the Mineralogic Model

Mineral Abundance (expressed in weight percent)

\begin{tabular}{|c|c|c|c|c|c|c|c|c|c|c|}
\hline \multirow[b]{3}{*}{ Unit } & \multicolumn{10}{|c|}{ Mineral Abundance (expressed in weight percent) } \\
\hline & \multicolumn{2}{|c|}{ Smectite-Illite } & \multicolumn{2}{|c|}{ Sorptive Zeolite } & \multicolumn{2}{|c|}{ Tridymite } & \multicolumn{2}{|c|}{ Cristobalite-Opal CT } & \multicolumn{2}{|c|}{ Quartz } \\
\hline & Average & $\begin{array}{l}\text { Standard } \\
\text { Deviation }\end{array}$ & Average & $\begin{array}{l}\text { Standard } \\
\text { Deviation }\end{array}$ & Average & $\begin{array}{l}\text { Standard } \\
\text { Deviation }\end{array}$ & Average & $\begin{array}{l}\text { Standard } \\
\text { Deviation }\end{array}$ & Average & $\begin{array}{l}\text { Standard } \\
\text { Deviation }\end{array}$ \\
\hline Tptpv2 & 3.13 & 2.27 & 3.40 & 4.32 & 0.00 & 0.00 & 11.17 & 3.05 & 3.24 & 1.53 \\
\hline Tptpv1 - Tpbt1 & 0.55 & 0.69 & 3.02 & 3.63 & 0.18 & 0.35 & 5.31 & 1.50 & 3.82 & 1.15 \\
\hline Tac4 & 0.76 & 0.55 & 3.02 & 3.33 & 0.05 & 0.14 & 5.75 & 1.29 & 7.83 & 1.86 \\
\hline Tac3 & 1.62 & 1.41 & 4.35 & 3.43 & 0.00 & 0.00 & 5.44 & 0.88 & 4.95 & 1.20 \\
\hline Tac2 & 1.50 & 1.49 & 5.50 & 3.17 & 0.00 & 0.00 & 5.79 & 0.90 & 5.53 & 0.99 \\
\hline Tac1 & 0.37 & 0.31 & 6.98 & 3.00 & 0.00 & 0.00 & 5.70 & 1.13 & 6.11 & 1.02 \\
\hline Tacbt & 4.54 & 2.36 & 5.99 & 3.86 & 0.00 & 0.00 & 5.39 & 0.81 & 8.95 & 2.49 \\
\hline
\end{tabular}

\begin{tabular}{|l|c|c|c|c|c|c|c|c|c|c|}
\hline & \multicolumn{9}{|c|}{ Mineral Abundance (expressed in weight percent) } \\
\cline { 2 - 12 } & \multicolumn{2}{|c|}{ Feldspars } & \multicolumn{2}{c|}{ Volcanic Glass } & \multicolumn{2}{c|}{ Analcime } & \multicolumn{2}{c|}{ Mica } & \multicolumn{2}{c|}{ Calcite } \\
\cline { 2 - 12 } \multicolumn{1}{c|}{ Unit } & Average & $\begin{array}{c}\text { Standard } \\
\text { Deviation }\end{array}$ & Average & $\begin{array}{c}\text { Standard } \\
\text { Deviation }\end{array}$ & Average & $\begin{array}{c}\text { Standard } \\
\text { Deviation }\end{array}$ & Average & $\begin{array}{c}\text { Standard } \\
\text { Deviation }\end{array}$ & $\begin{array}{c}\text { Standard } \\
\text { Average }\end{array}$ & $\begin{array}{c}\text { Stand } \\
\text { Deviation }\end{array}$ \\
\hline Tptpv2 & 20.57 & 9.39 & 59.08 & 8.91 & 0.00 & 0.00 & 0.23 & 0.14 & 0.02 & 0.03 \\
\hline Tptpv1 - Tpbt1 & 19.79 & 6.09 & 68.75 & 8.04 & 0.00 & 0.00 & 0.10 & 0.12 & 0.15 & 0.29 \\
\hline Tac4 & 27.02 & 3.98 & 56.56 & 6.16 & 0.00 & 0.00 & 0.55 & 0.17 & 0.00 & 0.00 \\
\hline Tac3 & 26.79 & 7.30 & 57.73 & 9.21 & 0.00 & 0.00 & 1.02 & 0.61 & 0.00 & 0.00 \\
\hline Tac2 & 26.36 & 8.04 & 55.93 & 8.86 & 0.00 & 0.00 & 1.05 & 0.56 & 0.01 & 0.03 \\
\hline Tac1 & 23.57 & 6.31 & 58.50 & 8.07 & 0.00 & 0.00 & 0.67 & 0.18 & 0.01 & 0.04 \\
\hline Tacbt & 33.62 & 2.77 & 39.96 & 6.06 & 0.00 & 0.00 & 1.91 & 0.23 & 1.32 & 0.23 \\
\hline
\end{tabular}

DTN: LA9908JC831321.001 [DIRS 113495].

NOTE: This table was developed by reformatting (Lum 2004 [DIRS 172044]) the mineral abundance values obtained with EARTHVISION. 
Table 6-4. Mineral Abundance of the Ten Mineral Groups in the Zeolitic Zones for Layers of the Mineralogic Model

\begin{tabular}{|c|c|c|c|c|c|c|c|c|c|c|}
\hline \multirow[b]{3}{*}{ Unit } & \multicolumn{10}{|c|}{ Mineral Abundance (expressed in weight percent) } \\
\hline & \multicolumn{2}{|c|}{ Smectite-Illite } & \multicolumn{2}{|c|}{ Sorptive Zeolite } & \multicolumn{2}{|c|}{ Tridymite } & \multicolumn{2}{|c|}{ Cristobalite-Opal CT } & \multicolumn{2}{|c|}{ Quartz } \\
\hline & Average & $\begin{array}{l}\text { Standard } \\
\text { Deviation }\end{array}$ & Average & $\begin{array}{l}\text { Standard } \\
\text { Deviation }\end{array}$ & Average & $\begin{array}{l}\text { Standard } \\
\text { Deviation }\end{array}$ & Average & $\begin{array}{l}\text { Standard } \\
\text { Deviation }\end{array}$ & Average & $\begin{array}{l}\text { Standard } \\
\text { Deviation }\end{array}$ \\
\hline Tptpv2 & 8.76 & 5.40 & 20.00 & 4.29 & 0.00 & 0.00 & 8.97 & 2.86 & 2.40 & 0.50 \\
\hline Tptpv1-Tpbt1 & 3.18 & 2.81 & 53.89 & 11.00 & 0.03 & 0.09 & 16.36 & 4.07 & 2.13 & 1.22 \\
\hline Tac4 & 1.33 & 0.42 & 54.18 & 16.79 & 0.00 & 0.01 & 17.42 & 3.25 & 4.52 & 1.47 \\
\hline Tac3 & 1.55 & 0.64 & 49.46 & 12.92 & 0.00 & 0.00 & 16.77 & 4.22 & 5.42 & 1.91 \\
\hline Tac2 & 1.37 & 0.62 & 50.94 & 11.48 & 0.00 & 0.00 & 16.72 & 4.70 & 5.40 & 2.75 \\
\hline Tac1 & 0.89 & 0.73 & 49.80 & 10.80 & 0.00 & 0.00 & 13.48 & 3.86 & 8.40 & 6.74 \\
\hline Tacbt & 5.29 & 3.37 & 27.45 & 8.23 & 0.00 & 0.00 & 4.90 & 4.27 & 19.07 & 6.40 \\
\hline
\end{tabular}

\begin{tabular}{|c|c|c|c|c|c|c|c|c|c|c|}
\hline \multirow[b]{3}{*}{ Unit } & \multicolumn{10}{|c|}{ Mineral Abundance (expressed in weight percent) } \\
\hline & \multicolumn{2}{|c|}{ Feldspars } & \multicolumn{2}{|c|}{ Volcanic Glass } & \multicolumn{2}{|c|}{ Analcime } & \multicolumn{2}{|c|}{ Mica } & \multicolumn{2}{|c|}{ Calcite } \\
\hline & Average & $\begin{array}{l}\text { Standard } \\
\text { Deviation }\end{array}$ & Average & $\begin{array}{l}\text { Standard } \\
\text { Deviation }\end{array}$ & Average & $\begin{array}{l}\text { Standard } \\
\text { Deviation }\end{array}$ & Average & $\begin{array}{l}\text { Standard } \\
\text { Deviation }\end{array}$ & Average & $\begin{array}{l}\text { Standard } \\
\text { Deviation }\end{array}$ \\
\hline Tptpv2 & 8.01 & 1.52 & 51.11 & 8.81 & 0.00 & 0.00 & 0.36 & 0.26 & 0.01 & 0.01 \\
\hline Tptpv1-Tpbt1 & 12.60 & 4.94 & 12.29 & 13.37 & 0.00 & 0.00 & 0.08 & 0.08 & 0.03 & 0.07 \\
\hline Tac4 & 20.58 & 11.26 & 5.86 & 10.14 & 0.00 & 0.00 & 0.34 & 0.34 & 0.00 & 0.00 \\
\hline Tac3 & 22.03 & 10.48 & 6.56 & 10.73 & 0.00 & 0.01 & 0.65 & 0.69 & 0.00 & 0.00 \\
\hline Tac2 & 21.05 & 7.92 & 6.54 & 11.28 & 0.01 & 0.01 & 0.77 & 0.90 & 0.00 & 0.01 \\
\hline Tac1 & 21.28 & 4.53 & 6.77 & 11.69 & 0.00 & 0.00 & 1.56 & 2.16 & 0.00 & 0.01 \\
\hline Tacbt & 33.28 & 5.74 & 6.64 & 8.36 & 0.00 & 0.00 & 2.05 & 1.52 & 0.11 & 0.21 \\
\hline
\end{tabular}

Source DTN: LA9908JC831321.001 [DIRS 113495].

NOTE: This table was developed by reformatting (Lum 2004 [DIRS 172044]) the mineral abundance values obtained with EARTHVISION 


\subsection{HEAT CAPACITY REPRESENTATIONS FOR THE MINERAL GROUPS}

In order to use Equation 6-1 to calculate the heat capacities of each layer, the heat capacities of the ten mineral groups must be determined. The heat capacity of minerals can be determined by using one of a variety of calorimetric techniques. The measured data is usually represented using "curve fit" equations or tables. To retain accuracy of measurement when analytical methods (i.e., equations) are used, proper representation of the data is important. To represent heat capacity as a function of temperature $(\mathrm{T})$, different investigators have used a number of different equations. Berman and Brown (1985 [DIRS 104907]) looked at numerous sources of heat capacity equations. Many of these equations (e.g., Robie et al. 1979 [DIRS 107109]) are applicable to heat capacity representation within the calorimetric measurement temperature range. Berman and Brown (1985 [DIRS 104907], Equation 7) presented the following heat capacity equation for minerals:

$$
C_{p}=k_{0}+k_{1} T^{-0.5}+k_{2} T^{-2}+k_{3} T^{-3}
$$

The coefficients $k_{0}, k_{1}, k_{2}$, and $k_{3}$ are determined so that Equation 6-2 best fits the experimental measurements of heat capacity for each mineral. Berman and Brown (1985 [DIRS 104907], p. 168) state that Equation 6-2 reproduces calorimetric data within the estimated precision of the measurements, and that heat capacity extrapolations should be reliable to considerably higher temperatures than those at which calorimetric data are available. The absolute deviation of Equation 6-2 from heat capacity data is less than one percent (Berman and Brown 1985 [DIRS 104907], Table 3, pp. 170-174). Chipera et al. (1995 [DIRS 100025], p. 569) used Equation 6-2 to fit heat capacity data of zeolites from different sources.

Robie et al. (1979 [DIRS 107109], p. 2) used Equation 6-3 to fit experimental mineral heat capacity data:

$$
C_{p}=A_{1}+A_{2} T+A_{3} T^{-2}+A_{4} T^{-0.5}+A_{5} T^{2}
$$

In Equation 6-3, $A_{1}, A_{2}, A_{3}, A_{4}$, and $A_{5}$ are determined so that Equation 6-3 best fits the experimental measurements of heat capacity for each mineral. Robie et al. (1979 [DIRS 107109], pp. 2 and 218) gives lower and upper limits of temperature for each mineral, and cautions that Equation 6-3 should not be extrapolated beyond the upper limit. The upper temperature limits are usually above the temperatures of interest in this analysis $\left(325^{\circ} \mathrm{C}\right)$ and, thus, extrapolations to such higher temperatures are not necessary. For this work, the heat capacity and formula weight data for tridymite in Thermodynamic Properties of Minerals and Related Substances at $298.15 \mathrm{~K}$ and 1 Bar (10 Pascals) Pressure and at Higher Temperatures (Robie et al. 1979 [DIRS 107109], p. 218) and the heat capacity and formula weight data for silica glasses in the later version of Thermodynamic Properties of Minerals and Related Substances at $298.15 \mathrm{~K}$ and 1 Bar $\left(10^{5}\right.$ Pascals) Pressure and at Higher Temperatures (Robie and Hemingway 1995 [DIRS 153683], pp. 31 to 40, 50, and 58 to 66) have been used (Appendix A). The temperature range for tridymite given by Robie et al. (1979 [DIRS 107109], p. 218) is $117^{\circ} \mathrm{C}$ to $1527^{\circ} \mathrm{C}$ (Appendix A); heat capacity data at $25^{\circ} \mathrm{C}$ were also provided, but data for temperatures in the range of $25^{\circ} \mathrm{C}$ to $117^{\circ} \mathrm{C}$ were not provided (it was reported as uncertain). For this study, a straight-line interpolation was used to provide heat capacity for this 
temperature range. A straight-line interpolation was chosen because it is the simplest means of interpolating between two points (from $25^{\circ} \mathrm{C}$ to $120^{\circ} \mathrm{C}$ ). By examination, the maximum difference in heat capacity between a fitted curve and linear interpolation over the temperature range is approximately 0.25 to $0.30 \mathrm{~J} / \mathrm{g}-\mathrm{K}$ (Figure A-3). The highest observed abundance of tridymite is approximately 10 percent (Table 6-2). Therefore, it is estimated that the largest change in rock-grain heat capacity would be an increase of $0.03 \mathrm{~J} / \mathrm{g}-\mathrm{K}$, which is well within the parameter uncertainty, and is deemed to be insignificant.

For analcime, Johnson et al. (1982 [DIRS 106283], p. 744, Equation 4) use the following equation:

$$
C_{p}=A_{1}+A_{2} T+A_{3} T^{2}+A_{4} T^{3}
$$

The heat capacity equations used in DTNs MO0009THRMODYN.001 [DIRS 152576] and MO0302SPATHDYN.001 [DIRS 161886] are given here as Equations 6-2, 6-3, 6-4, 6-5, 6-6, and 6-7. Equation 6-5, Equation 6-6, and Equation 6-7 are truncated forms of Equation 6-3.

$$
\begin{gathered}
C_{p}=A_{1}+A_{2} T+A_{3} T^{-2} \\
C_{p}=A_{1}+A_{2} T+A_{3} T^{2} \\
C_{p}=A_{1}+A_{2} T+A_{3} T^{-0.5}+A_{4} T^{-2}
\end{gathered}
$$

A listing of the heat capacity equations used for each mineral, together with other relevant information, is provided in Appendix A, and summarized in Table 6-5.

Table 6-5. Temperature-Dependant Heat Capacity Equations for Different Minerals

\begin{tabular}{|l|l|}
\hline \multicolumn{1}{|c|}{ Mineral } & \multicolumn{1}{c|}{ Equation $^{\text {a }}$} \\
\hline $\begin{array}{l}\text { Smectite, illite, mordenite, cristobalite, quartz, k-feldspar, } \\
\text { CaSiO }\end{array}$, muscovite, calcite & $C_{p}=A_{1}+A_{2} T+A_{3} T^{-2}$ \\
\hline Clinoptilolite & $C_{p}=A_{1}+A_{2} T+A_{3} T^{2}$ \\
\hline Chabazite, erionite, stellerite & $C_{p}=k_{0}+k_{1} T^{-0.5}+k_{2} T^{-2}+k_{3} T^{-3}$ \\
\hline Tridymite, $\mathrm{Mg}_{3} \mathrm{Al}_{2} \mathrm{Si}_{3} \mathrm{O}_{2}, \mathrm{NaAlSiO}_{4}$ & $C_{p}=A_{1}+A_{2} T+A_{3} T^{-0.5}+A_{4} T^{-2}$ \\
\hline $\mathrm{CaMgSi}_{2} \mathrm{O}_{6}, \mathrm{KAISi}_{3} \mathrm{O}_{8}, \mathrm{NaAlSi}_{3} \mathrm{O}_{8}$ & $C_{p}=A_{1}+A_{2} T+A_{3} T^{-2}+A_{4} T^{-0.5}+A_{5} T^{2}$ \\
\hline Analcime & $C_{p}=A_{1}+A_{2} T+A_{3} T^{2}+A_{4} T^{3}$ \\
\hline
\end{tabular}

${ }^{a}$ The constants of the equations given in Table 6-5 are different for each mineral and are given in Appendix A.

The units of heat capacity are presented in $\mathrm{J} / \mathrm{g}-\mathrm{K}$ (all have been converted from their original units). A heat capacity value averaged over a temperature range of $25^{\circ} \mathrm{C}$ to $325^{\circ} \mathrm{C}$ is also given for each mineral. If a simplification or an average value for the mineral group was used in the analysis, the group averaged-value over the temperature range of $25^{\circ} \mathrm{C}$ to $325^{\circ} \mathrm{C}$ is also provided. 
The evaluation of these equations over the temperature range is provided in output DTN: SN0409T0510902.004.

Silica oxide polymorphs such as tridymite and cristobalite exhibit phase transformations at different temperatures (Thompson and Wennemer 1979 [DIRS 111126], pp. 1018 to 1025). Thompson and Wennemer report major transitions for synthetic tridymite at $390 \mathrm{~K}\left(116.85^{\circ} \mathrm{C}\right)$ and $436 \mathrm{~K}\left(162.85^{\circ} \mathrm{C}\right)$, and for synthetic cristobalite at $535 \mathrm{~K}\left(261.85^{\circ} \mathrm{C}\right)$. These transitions absorb heat and, therefore, increase the heat capacity of the minerals as a function of temperature (Nimick and Connolly 1991 [DIRS 100690], p. 20). Nimick and Connolly estimated the increase in heat capacity due to the phase transitions, and showed that the heat capacity increase for tridymite is much lower than that of cristobalite. As shown in American Mineralogist, 64, in "Heat Capacities and Inversions in Tridymite, Cristobalite, and Tridymite-Cristobalite Mixed Phases" (Thompson and Wennemer 1979 [DIRS 111126], Figures 1 and 2), the transitions cause relatively narrow spikes in the heat capacity-temperature plot. As mentioned earlier, the equation for tridymite given by Robie et al. (1979 [DIRS 107109]) has a lower limit of $117^{\circ} \mathrm{C}$, which is also the lower temperature-transition of Thompson and Wennemer (1979 [DIRS 111126]). The equation does not show the upper temperature-transition of Thompson and Wennemer (1979 [DIRS 111126]). Thompson and Wennemer (1979 [DIRS 111126], p. 1022) report the $\alpha$-to- $\beta$ transformation for cristobalite ( $\alpha: 298 \mathrm{~K}$ to $523 \mathrm{~K}$, and $\beta: 523 \mathrm{~K}$ to $2000 \mathrm{~K}$ ) at $523 \mathrm{~K}\left(249.85^{\circ} \mathrm{C}\right)$.

DTN: MO0009THRMODYN.001 [DIRS 152576] gives separate heat capacity equations for $\alpha$ and $\beta$ cristobalite, with temperature limits of $726.85^{\circ} \mathrm{C}$ and $1726.85^{\circ} \mathrm{C}$, respectively. Neither of these equations includes the heat capacity spike at transition (see Figure A-4 of this report for $\alpha$ cristobalite). For this study, a decision was made to use the equation for $\alpha$ cristobalite because it covers the temperature range of interest. Also, for heat capacity values averaged over a temperature range (Section 6.5 and Appendix A of this report), the effect of the phase-transformation heat capacity spikes is minimal.

\subsection{HEAT CAPACITY VALUES OF THE TEN MINERAL GROUPS}

Heat capacity data for the majority of the mineral groups (smectite, illite, cristobalite, quartz, feldspar, muscovite, and calcite) were obtained from DTN: MO0009THRMODYN.001 [DIRS 152576]. The heat capacity data for tridymite are from Robie et al. (1979 [DIRS 107109], p. 218), and the heat capacity data for silica glasses are from Robie and Hemingway (1995 [DIRS 153683], pp. 31 to 40, 50, and 58 to 66). Heat capacity data for chabazite, erionite, and stellerite are from Chipera et al. (1995 [DIRS 100025]); heat capacity data for clinoptilolite and for mordenite are from DTN: MO0302SPATHDYN.001 [DIRS 161886]; and heat capacity data for analcime are from Johnson et al. (1982 [DIRS 106283], p. 744, Equation 4). These data are summarized in Appendix A.

In general, the heat capacity values for the individual mineral species primarily depend on chemical composition. For mineral species that are combined into mineral groups, and that share a common structure and composition, their heat capacity behavior will also be similar. Therefore, simplifications that select, average, or combine heat capacity values for the mineral groups are justifiable; the specific simplifications made for the ten different mineral groups, and their justification, are discussed in Section 5. 


\subsection{CALCULATION OF ROCK-GRAIN HEAT CAPACITY}

Calculation of the rock-grain heat capacity of each of the mineralogic model layers was done following Kopp's law (Nimick and Connolly 1991 [DIRS 100690], p. 6). Based on the temperature-dependant heat capacity equations presented in Appendix A, the rock-grain heat capacity was determined for four temperature intervals: $25^{\circ} \mathrm{C}$ to $325^{\circ} \mathrm{C}, 25^{\circ} \mathrm{C}$ to $95^{\circ} \mathrm{C}, 95^{\circ} \mathrm{C}$ to $114^{\circ} \mathrm{C}$, and $114^{\circ} \mathrm{C}$ to $325^{\circ} \mathrm{C}$. The results of these calculations are presented in Tables 6-6 and 6-7.

Appendix B provides a comparison of rock-grain heat capacities developed in this analysis to data from three other sources: DTNs SN0210T0510902.001 [DIRS 161244], SN0402T0503102.010 [DIRS 170993], and SN0303T0510902.002 [DIRS 162496]. The data in DTN: SN0402T0503102.010 [DIRS 170993] were based on the oxide (major element) summation method. The data in DTNs SN0210T0510902.001 [DIRS 161244] and SN0303T0510902.002 [DIRS 162496] were developed using the same method used in this analysis (the mineral summation method). The mean values of rock-grain heat capacity compare favorably for the two methods. Output DTN: SN0307T0510902.003 incorporates corrections and changes required by the checking process per AP-SIII.9Q.

For completeness, the equations used to estimate the average and standard deviations of the rock-grain heat capacities are given below. These statistical measures, provided in Tables 6-6 and 6-7, were developed following the principles outlined in Bulmer (1979 [DIRS 111961], pp. 71 to 73). The calculated average and standard deviations are the result of propagating uncertainties in the mineral abundance and mineral heat capacity through Kopp's law.

Equation 6-8 denotes the $j$ th mineral's contribution to the rock-grain heat capacity (i.e., the product of mineral abundance, $x_{j}$, expressed as a weight fraction; and mineral heat capacity, $C_{p j}$ ) by $P_{j}$ :

$$
P_{j}=x_{j} \cdot C_{p j}
$$

With this substitution, Equation 6-5 becomes

$$
C_{p, g}=\sum_{j=1}^{j=n} x_{j} \cdot C_{p j}=\sum_{j=1}^{j=n} P_{j}
$$

The expected (or average) value of $C_{p, g}$ over a specified temperature range, denoted $E\left[C_{p, g}\right\rfloor$, can be written as the sum of the expected values of the individual mineral contributions $E\left[P_{j}\right]$, where $j=1$ to $n$ and $n$ is the number of mineral components.

$$
E\left[C_{p, g}\right]=\sum_{j=1}^{j=n} E\left[P_{j}\right]
$$


Treating $x_{j}$ and $C_{p j}$ as independent random variables (i.e., the abundance of the mineral should not be dependent on the mineral's heat capacity), the expected value of the $j$ th mineral's contribution to the rock-grain heat capacity may be written as

$$
E\left[P_{j}\right]=E\left[x_{j}\right] \cdot E\left[C_{p j}\right]
$$

$E\left[x_{j}\right]$ is the expected value of the mineral abundance $x_{j}$ of mineral $j$ in a particular lithostratigraphic layer. The variability of $C_{p j}$ is due to the temperature dependence of the heat capacity of individual minerals expressed by Equations 6-2 to 6-7. $E\left[C_{p j}\right]$ is the expected value of the heat capacity $C_{p j}$ over a specified temperature range. The variability of $C_{p j}$ is due to the temperature dependence of the heat capacity of individual minerals expressed by Equations 6-2 to 6-7. Combining Equation 6-10 and Equation 6-11 gives the equation for the expected or average value of the rock-grain heat capacity in terms of mineral abundance expressed in terms of weight fraction, $x_{j}$ (Equation 6-12), and weight percent, $\overline{x_{j}}$ (Equation 6-13).

$$
\begin{aligned}
& E\left[C_{p, g}\right]=\sum_{j=1}^{j=n} E\left[x_{j}\right] \cdot E\left[C_{p j}\right] \\
& E\left[C_{p, g}\right]=\frac{\sum_{j=1}^{j=n} E\left[\overline{x_{j}}\right] \cdot E\left[C_{p j}\right]}{\sum_{j=1}^{j=n} \overline{x_{j}}}
\end{aligned}
$$

Similarly, the variance of $C_{p, g}$, denoted $\left.V \mid C_{p, g}\right]$, can be written as the sum of the variances of the individual mineral contributions, $V\left[P_{j}\right\rfloor$.

$$
V\left[C_{p, g}\right]=\sum_{j=1}^{j=n} V\left[P_{j}\right]
$$

The variance of $P_{j}$ is given by

$$
V\left[P_{j}\right]=\left(\frac{\partial P_{j}}{\partial x_{j}}\right)^{2} \cdot V\left[x_{j}\right]+\left(\frac{\partial P_{j}}{\partial C_{p j}}\right)^{2} \cdot V\left[C_{p j}\right]
$$

The partial derivatives in Equation 6-15 are evaluated using Equation 6-8 to give

$$
V\left[P_{j}\right]=\left(E\left[C_{p j}\right]\right)^{2} \cdot V\left[x_{j}\right]+\left(E\left[x_{j}\right]\right)^{2} \cdot V\left[C_{p j}\right]
$$


When mineral abundance is expressed as a weight fraction, $\left(x_{j}\right)$, Equation 6-17 is used to calculate the standard deviation for the rock-grain heat capacity, $\left.\sigma \mid C_{p, g}\right\rfloor$. For mineral abundance expressed as a weight percent, $\overline{x_{j}}$, Equation 6-18 is used.

$$
\begin{aligned}
& \sigma\left[C_{p, g}\right]=\sqrt{\sum_{j=1}^{j=n}\left(\left(E\left[C_{p j}\right] \cdot \sigma\left[x_{j}\right]\right)^{2}+\left(E\left[x_{j}\right] \cdot \sigma\left[C_{p j}\right]\right)^{2}\right)} \\
& \sigma\left[C_{p, g}\right]=\frac{\sqrt{\sum_{j=1}^{j=n}\left(\left(E\left[C_{p j}\right] \cdot \sigma\left[\overline{x_{j}}\right]\right)^{2}+\left(E\left[\overline{x_{j}}\right] \cdot \sigma\left[C_{p j}\right]\right)^{2}\right)}}{\sum_{j=1}^{j=n} \overline{x_{j}}}
\end{aligned}
$$

where the definition $\mathrm{V}[]=(\sigma[])^{2}$ has been employed. The standard deviations given by Equation 6-17 and Equation 6-18 are with respect to the mean heat capacity over each temperature range. Equation 6-13 and Equation 6-18 were used to estimate the rock-grain heat-capacities statistics (average and standard deviation) for each layer and temperature interval given in Tables 6-6 and 6-7.

\subsection{CALCULATION OF ROCK-MASS HEAT CAPACITY}

Once the rock-grain heat capacities have been determined, the heat capacity of the rock mass can then be obtained. For temperatures below boiling, taken in this analysis to be $25^{\circ} \mathrm{C}$ to $95^{\circ} \mathrm{C}$, the volumetric heat capacity of the rock mass, $\left(\rho C_{p}\right)_{r m}$, can be expressed as the summation of the contributions of the solid matrix, the moisture in the matrix, and the air in the matrix and the lithophysae.

$$
\begin{gathered}
\left(\rho C_{p}\right)_{r m}=\rho_{g}\left(1-\phi_{m}\right)\left(1-\phi_{L}\right) C_{p, g}+\rho_{w}\left(1-\phi_{L}\right) \phi_{m} S_{w} C_{p, w}+\rho_{a}\left[\phi_{L}+\left(1-\phi_{L}\right) \phi_{m}\left(1-S_{w}\right)\right] C_{p, a} \\
\approx \rho_{g}\left(1-\phi_{m}\right)\left(1-\phi_{L}\right) C_{p, g}+\rho_{w}\left(1-\phi_{L}\right) \phi_{m} S_{w} C_{p, w}
\end{gathered}
$$

where:

$\left(\rho C_{p}\right)_{r m}$ is the volumetric heat capacity of the rock mass, $\mathrm{J} / \mathrm{m}^{3}-\mathrm{K}$

$\phi_{m}$ is matrix porosity, $\mathrm{m}^{3} / \mathrm{m}^{3}$

$\phi_{L}$ is the volume fraction of lithophysal cavities, $\mathrm{m}^{3} / \mathrm{m}^{3}$

$C_{p, g}$ is the rock-grain heat capacity, $\mathrm{J} / \mathrm{kg}-\mathrm{K}$

$S_{w}$ is the matrix water saturation, $\mathrm{m}^{3} / \mathrm{m}^{3}$

$C_{p, w}$ and $C_{p, a}$ are the heat capacity of water and air, respectively, $\mathrm{J} / \mathrm{kg}-\mathrm{K}$

$\rho_{g}$ is the rock-grain density, $\mathrm{kg} / \mathrm{m}^{3}$

$\rho_{w}$ and $\rho_{a}$ are the densities of water and air, respectively, $\mathrm{kg} / \mathrm{m}^{3}$. 
The heat capacity of the rock mass is then

$$
C_{p, r m}=\frac{\left(\rho C_{p}\right)_{r m}}{\rho_{r m}} \approx \frac{\left(\rho C_{p}\right)_{r m}}{\rho_{g}\left(1-\phi_{L}\right)\left(1-\phi_{m}\right)+\left(1-\phi_{L}\right) \phi_{m} S_{w} \rho_{w}}
$$

Table 6-6. Rock-Grain Heat Capacities for Lithostratigraphic Units

\begin{tabular}{|c|c|c|c|c|c|c|c|c|}
\hline \multirow[b]{3}{*}{$\begin{array}{c}\text { Mineralogic } \\
\text { Model Unit }\end{array}$} & \multicolumn{8}{|c|}{ Rock-Grain Heat Capacity ${ }^{\mathrm{a}}(\mathrm{J} / \mathrm{g}-\mathrm{K})$} \\
\hline & \multicolumn{2}{|c|}{ for $\mathrm{T}=25^{\circ} \mathrm{C}$ to $325^{\circ} \mathrm{C}$} & \multicolumn{2}{|c|}{ for $\mathrm{T}=25^{\circ} \mathrm{C}$ to $95^{\circ} \mathrm{C}$} & \multicolumn{2}{|c|}{ for $\mathrm{T}=95^{\circ} \mathrm{C}$ to $114^{\circ} \mathrm{C}$} & \multicolumn{2}{|c|}{ for $\mathrm{T}=114^{\circ} \mathrm{C}$ to $325^{\circ} \mathrm{C}$} \\
\hline & Average & $\begin{array}{l}\text { Standard } \\
\text { Deviation }\end{array}$ & Average & $\begin{array}{l}\text { Standard } \\
\text { Deviation }\end{array}$ & Average & $\begin{array}{l}\text { Standard } \\
\text { Deviation }\end{array}$ & Average & $\begin{array}{l}\text { Standard } \\
\text { Deviation } \\
\end{array}$ \\
\hline Tpc_uni & 0.93 & 0.11 & 0.79 & 0.08 & 0.87 & 0.08 & 0.99 & 0.10 \\
\hline $\begin{array}{l}\text { Tpcpv3- } \\
\text { Tpcpv2 }\end{array}$ & 0.95 & 0.11 & 0.83 & 0.09 & 0.90 & 0.09 & 1.00 & 0.10 \\
\hline PTn $^{\mathrm{b}}$ & 0.96 & 0.23 & 0.84 & 0.20 & 0.90 & 0.22 & 1.00 & 0.24 \\
\hline Tptrv1 & 0.95 & 0.10 & 0.84 & 0.08 & 0.90 & 0.08 & 0.99 & 0.10 \\
\hline $\begin{array}{l}\text { Tptrn-Tptrl- } \\
\text { Tptf }\end{array}$ & 0.93 & 0.13 & 0.78 & 0.10 & 0.87 & 0.10 & 0.99 & 0.12 \\
\hline Tptpul & 0.93 & 0.12 & 0.78 & 0.09 & 0.87 & 0.09 & 0.99 & 0.11 \\
\hline Tptpmn & 0.93 & 0.14 & 0.78 & 0.11 & 0.87 & 0.11 & 0.99 & 0.13 \\
\hline Tptpll & 0.93 & 0.13 & 0.78 & 0.10 & 0.87 & 0.10 & 0.99 & 0.12 \\
\hline Tptpln & 0.93 & 0.10 & 0.78 & 0.07 & 0.87 & 0.07 & 0.99 & 0.09 \\
\hline Tptpv3 & 0.98 & 0.24 & 0.86 & 0.21 & 0.93 & 0.23 & 1.02 & 0.25 \\
\hline Tptpv $2^{c}$ & 0.98 & 0.19 & 0.86 & 0.16 & 0.93 & 0.17 & 1.02 & 0.19 \\
\hline Tptpv1-Tpbt1 & 1.08 & 0.42 & 0.95 & 0.37 & 1.02 & 0.40 & 1.12 & 0.43 \\
\hline Tac4 & 1.07 & 0.42 & 0.93 & 0.38 & 1.01 & 0.40 & 1.12 & 0.44 \\
\hline Tac3 & 1.07 & 0.38 & 0.93 & 0.33 & 1.01 & 0.36 & 1.12 & 0.39 \\
\hline Tac2 & 1.07 & 0.36 & 0.94 & 0.32 & 1.01 & 0.34 & 1.12 & 0.38 \\
\hline Tac1 & 1.07 & 0.35 & 0.94 & 0.31 & 1.01 & 0.33 & 1.12 & 0.37 \\
\hline Tacbt $^{\mathrm{c}}$ & 1.02 & 0.24 & 0.88 & 0.21 & 0.95 & 0.22 & 1.07 & 0.25 \\
\hline Tcpuv & 1.04 & 0.28 & 0.90 & 0.24 & 0.98 & 0.26 & 1.09 & 0.29 \\
\hline $\begin{array}{l}\text { Tcpuc- } \\
\text { Tcpmd-Tcplc } \\
\end{array}$ & 0.93 & 0.13 & 0.78 & 0.10 & 0.87 & 0.10 & 0.99 & 0.12 \\
\hline $\begin{array}{l}\text { Tcplv-Tcpbt- } \\
\text { Tcbuv }^{\text {e }}\end{array}$ & 1.10 & 0.19 & 0.96 & 0.16 & 1.04 & 0.17 & 1.15 & 0.19 \\
\hline $\begin{array}{l}\text { Tcbuc- } \\
\text { Tcbmd-Tcblc }^{f}\end{array}$ & 0.93 & 0.12 & 0.78 & 0.09 & 0.87 & 0.09 & 0.99 & 0.10 \\
\hline $\begin{array}{l}\text { Tcblv-Tcbbt- } \\
\text { Tctuv }^{\text {g }}\end{array}$ & 1.05 & 0.22 & 0.90 & 0.19 & 0.98 & 0.20 & 1.10 & 0.22 \\
\hline $\begin{array}{l}\text { Tctuc-Tctmd- } \\
\text { Tctlc }\end{array}$ & 0.94 & 0.12 & 0.78 & 0.09 & 0.87 & 0.09 & 0.99 & 0.11 \\
\hline
\end{tabular}


Table 6-6. Rock-Grain Heat Capacities for Lithostratigraphic Units (Continued)

\begin{tabular}{|c|c|c|c|c|c|c|c|c|}
\hline \multirow[b]{3}{*}{$\begin{array}{c}\text { Mineralogic } \\
\text { Model Unit }\end{array}$} & \multicolumn{8}{|c|}{ Rock-Grain Heat Capacity ${ }^{a}(\mathrm{~J} / \mathrm{g}-\mathrm{K})$} \\
\hline & \multicolumn{2}{|c|}{ for $\mathrm{T}=25^{\circ} \mathrm{C}$ to $325^{\circ} \mathrm{C}$} & \multicolumn{2}{|c|}{ for $\mathrm{T}=25^{\circ} \mathrm{C}$ to $95^{\circ} \mathrm{C}$} & \multicolumn{2}{|c|}{ for $\mathrm{T}=95^{\circ} \mathrm{C}$ to $114^{\circ} \mathrm{C}$} & \multicolumn{2}{|c|}{ for $\mathrm{T}=114^{\circ} \mathrm{C}$ to $325^{\circ} \mathrm{C}$} \\
\hline & Average & $\begin{array}{l}\text { Standard } \\
\text { Deviation }\end{array}$ & Average & $\begin{array}{l}\text { Standard } \\
\text { Deviation }\end{array}$ & Average & $\begin{array}{l}\text { Standard } \\
\text { Deviation }\end{array}$ & Average & $\begin{array}{l}\text { Standard } \\
\text { Deviation }\end{array}$ \\
\hline Tctlv-Tctbt & 0.94 & 0.12 & 0.78 & 0.09 & 0.87 & 0.09 & 0.99 & 0.11 \\
\hline Tund & 0.96 & 0.13 & 0.82 & 0.11 & 0.90 & 0.11 & 1.02 & 0.13 \\
\hline
\end{tabular}

${ }^{a}$ The data given in this table are from output DTN: SN0307T0510902.003, Excel workbook

rock_grain_heat_capacity.xls, which has 4 sheets (“Cp grain 25-325," "Cp grain 25-94," "Cp grain 95-114," and “Cp grain 115-325”):

"Cp grain 25-325" (Columns $\mathrm{Y}$ and $\mathrm{Z}$ ) contains the data for $\mathrm{T}=25^{\circ} \mathrm{C}$ to $325^{\circ} \mathrm{C}$ (Columns 2 and 3 in Table 6-6).

"Cp grain 25-94" (Columns $Y$ and Z) contains the data for $\mathrm{T}=25^{\circ} \mathrm{C}$ to $95^{\circ} \mathrm{C}$ (Columns 4 and 5 in Table 6-6).

"Cp grain 95-114" (Columns $Y$ and Z) contains the data for $\mathrm{T}=95^{\circ} \mathrm{C}$ to $114^{\circ} \mathrm{C}$ (Columns 6 and 7 in Table 6-6).

"Cp grain 115-325" (Columns $\mathrm{Y}$ and $\mathrm{Z}$ ) contains the data for $\mathrm{T}=114^{\circ} \mathrm{C}$ to $325^{\circ} \mathrm{C}$ (Columns 8 and 9 in Table 6-6).

b PTn = Tpcpv1, Tpbt4, Tpy, Tpbt3, Tpp, Tpbt2, Tptrv3, Tptrv2.

c In addition to the heat capacity values for layers Tptpv2-Tacbt given in Table 6-6, separate estimates for the vitric and zeolitic zones of these layers are given in Table 6-7.

d Tcpuc-Tcpmd-Tcplc is the same as unit Tcpuc-Tcplc in the mineralogic model. The mineralogic model name was expanded to indicate that this unit also includes the stratigraphic unit Tcpmd.

e Tcplv-Tcpbt-Tcbuv is the same as unit Tcplv-Tcbuv in the mineralogic model. The mineralogic model name was expanded to indicate that this unit also includes the stratigraphic unit Tcpbt.

$f$ Tcbuc-Tcbmd-Tcblc is the same as unit Tcbuc-Tcblc in the mineralogic model. The mineralogic model name was expanded to indicate that this unit also includes the stratigraphic unit Tcbmd.

g Tcblv-Tcbbt-Tctuv is the same as unit Tcblv-Tctuv in the mineralogic model. The mineralogic model name was expanded to indicate that this unit also includes the stratigraphic unit Tcbbt.

$\mathrm{h}$ Tctuc-Tctmd-Tctlc is the same as unit Tctuc-Tctlc in the mineralogic model. The mineralogic model name was expanded to indicate that this unit also includes the stratigraphic unit Tctmd.

i Tpc_un is the same as unit Alluvium-Tpc_un in the mineralogic model.

Table 6-7. Rock-Grain Heat Capacities for Lithostratigraphic Units Tptpv2-Tacbt

\begin{tabular}{|c|c|c|c|c|c|c|c|c|}
\hline \multirow[b]{3}{*}{$\begin{array}{c}\text { Mineralogic } \\
\text { Model Unit }\end{array}$} & \multicolumn{8}{|c|}{ Rock-Grain Heat Capacity ${ }^{\mathrm{a}}$ (J/g-K) } \\
\hline & \multicolumn{2}{|c|}{ for $\mathrm{T}=25^{\circ} \mathrm{C}$ to $325^{\circ} \mathrm{C}$} & \multicolumn{2}{|c|}{ for $\mathrm{T}=25^{\circ} \mathrm{C}$ to $95^{\circ} \mathrm{C}$} & \multicolumn{2}{|c|}{ for $\mathrm{T}=95^{\circ} \mathrm{C}$ to $114^{\circ} \mathrm{C}$} & \multicolumn{2}{|c|}{ for $\mathrm{T}=114^{\circ} \mathrm{C}$ to $325^{\circ} \mathrm{C}$} \\
\hline & Average & $\begin{array}{l}\text { Standard } \\
\text { Deviation }\end{array}$ & Average & $\begin{array}{l}\text { Standard } \\
\text { Deviation }\end{array}$ & Average & $\begin{array}{l}\text { Standard } \\
\text { Deviation }\end{array}$ & Average & $\begin{array}{l}\text { Standard } \\
\text { Deviation }\end{array}$ \\
\hline \multicolumn{9}{|l|}{ Vitric $^{\mathrm{b}}$} \\
\hline Tptpv2 & 0.96 & 0.15 & 0.84 & 0.12 & 0.90 & 0.13 & 1.00 & 0.15 \\
\hline Tptpv1-Tpbt1 & 0.96 & 0.12 & 0.84 & 0.09 & 0.90 & 0.10 & 1.00 & 0.11 \\
\hline Tac4 & 0.96 & 0.10 & 0.83 & 0.08 & 0.90 & 0.08 & 1.00 & 0.09 \\
\hline Tac3 & 0.96 & 0.13 & 0.84 & 0.11 & 0.91 & 0.11 & 1.01 & 0.13 \\
\hline Tac2 & 0.96 & 0.13 & 0.84 & 0.11 & 0.91 & 0.11 & 1.01 & 0.13 \\
\hline Tac1 & 0.97 & 0.11 & 0.85 & 0.09 & 0.91 & 0.10 & 1.01 & 0.11 \\
\hline Tacbt & 0.97 & 0.10 & 0.84 & 0.08 & 0.91 & 0.08 & 1.01 & 0.09 \\
\hline \multicolumn{9}{|l|}{ Zeolitic $^{\text {b }}$} \\
\hline Tptpv2 & 1.02 & 0.13 & 0.90 & 0.11 & 0.96 & 0.11 & 1.06 & 0.13 \\
\hline Tptpv1-Tpbt1 & 1.12 & 0.21 & 0.99 & 0.18 & 1.06 & 0.19 & 1.17 & 0.21 \\
\hline Tac4 & 1.11 & 0.25 & 0.97 & 0.22 & 1.05 & 0.24 & 1.16 & 0.26 \\
\hline Tac3 & 1.10 & 0.22 & 0.96 & 0.19 & 1.04 & 0.20 & 1.15 & 0.23 \\
\hline Tac2 & 1.10 & 0.20 & 0.97 & 0.18 & 1.04 & 0.19 & 1.16 & 0.21 \\
\hline
\end{tabular}


Table 6-7. Rock-Grain Heat Capacities for Lithostratigraphic Units Tptpv2-Tacbt (Continued)

\begin{tabular}{|c|c|c|c|c|c|c|c|c|}
\hline \multirow[b]{3}{*}{$\begin{array}{l}\text { Mineralogic } \\
\text { Model Unit }\end{array}$} & \multicolumn{8}{|c|}{ Rock-Grain Heat Capacity ${ }^{a}$ (J/g-K) } \\
\hline & \multicolumn{2}{|c|}{ for $\mathrm{T}=25^{\circ} \mathrm{C}$ to $325^{\circ} \mathrm{C}$} & \multicolumn{2}{|c|}{ for $\mathrm{T}=25^{\circ} \mathrm{C}$ to $95^{\circ} \mathrm{C}$} & \multicolumn{2}{|c|}{ for $\mathrm{T}=95^{\circ} \mathrm{C}$ to $114^{\circ} \mathrm{C}$} & \multicolumn{2}{|c|}{ for $\mathrm{T}=114^{\circ} \mathrm{C}$ to $325^{\circ} \mathrm{C}$} \\
\hline & Average & $\begin{array}{l}\text { Standard } \\
\text { Deviation }\end{array}$ & Average & $\begin{array}{l}\text { Standard } \\
\text { Deviation }\end{array}$ & Average & $\begin{array}{l}\text { Standard } \\
\text { Deviation }\end{array}$ & Average & $\begin{array}{l}\text { Standard } \\
\text { Deviation }\end{array}$ \\
\hline Tac1 & 1.10 & 0.20 & 0.96 & 0.17 & 1.04 & 0.18 & 1.15 & 0.20 \\
\hline Tacbt & 1.03 & 0.17 & 0.89 & 0.15 & 0.97 & 0.16 & 1.09 & 0.17 \\
\hline
\end{tabular}

Output DTN: SN0307T0510902.003.

${ }^{a}$ The data given in this table are from output DTN: SN0307T0510902.003, Excel workbook rock_grain_heat_capacity.xls, which has 4 sheets (“Cp grain 25-325," "Cp grain 25-94," "Cp grain 95-114," and “Cp grain 115-325"):

"Cp grain 25-325" (Columns $\mathrm{Y}$ and $\mathrm{Z}$ ) contains the data for $\mathrm{T}=25^{\circ} \mathrm{C}$ to $325^{\circ} \mathrm{C}$ (Columns 2 and 3 in Table 6-7). "Cp grain 25-94" (Columns $Y$ and $Z$ ) contains the data for $\mathrm{T}=25^{\circ} \mathrm{C}$ to $95^{\circ} \mathrm{C}$ (Columns 4 and 5 in Table 6-7).

"Cp grain 95-114" (Columns $Y$ and $Z$ ) contains the data for $\mathrm{T}=95^{\circ} \mathrm{C}$ to $114^{\circ} \mathrm{C}$ (Columns 6 and 7 in Table 6-7).

"Cp grain 115-325" (Columns $\mathrm{Y}$ and $\mathrm{Z}$ ) contains the data for $\mathrm{T}=114^{\circ} \mathrm{C}$ to $325^{\circ} \mathrm{C}$ (Columns 8 and 9 in Table 6-7).

${ }^{b}$ The definitions of the vitric and zeolitic lithostratigraphic layers are presented in Section 6.3.

The simplification of Equation 6-19 and Equation 6-20 results from the low density of air; the products $\left[\phi_{L}+\left(1-\phi_{L}\right) \phi_{m}\left(1-S_{w}\right)\right] \rho_{a} C_{p, a}$ and $\left[\phi_{L}+\left(1-\phi_{L}\right) \phi_{m}\left(1-S_{w}\right)\right] \rho_{a}$ are negligible relative to the first two terms of each equation. Substituting Equation 6-19 into Equation 6-20 yields:

$$
C_{p, r m}=\frac{\rho_{g}\left(1-\phi_{m}\right)\left(1-\phi_{L}\right) C_{p, g}+\rho_{w}\left(1-\phi_{L}\right) \phi_{m} S_{w} C_{p, w}}{\rho_{g}\left(1-\phi_{L}\right)\left(1-\phi_{m}\right)+\left(1-\phi_{L}\right) \phi_{m} S_{w} \rho_{w}}=\frac{\rho_{g}\left(1-\phi_{m}\right) C_{p, g}+\rho_{w} \phi_{m} S_{w} C_{p, w}}{\rho_{g}\left(1-\phi_{m}\right)+\phi_{m} S_{w} \rho_{w}} \text { (Eq. 6-21) }
$$

As can be seen from Equation 6-21, the rock-mass heat capacity is independent of the lithophysal porosity, as the latter is factored out from the expression for $C_{p, r m}$. Equation 6-19 and Equation 6-20 are based on the assumption stated in Section 5 that the fracture porosity ( $\left.\phi_{f}\right)$ does not significantly contribute to $C_{p, r m}$ or $\left(\rho C_{p}\right)_{r m}$. The rock-matrix properties (grain density, porosity, and water saturation) vary spatially. Their average values and standard deviations within each unit are presented in Table 6-8. The number of samples used to determine these statistics is also given in Table 6-8. The matrix properties input data, obtained from the sources listed in Table 4-3 (DTNs: MO0109HYMXPROP.001 [DIRS 155989], GS980808312242.014 [DIRS 106748], and GS980708312242.010 [DIRS 106752]), were compiled and sorted in Excel based on the lithostratigraphic contacts provided in Table 4-4 (DTNs: MO0004QGFMPICK.000 [DIRS 152554] and SNF40060298001.001 [DIRS 107372]). The matrix property data were sorted based on the borehole and depth to the lithostratigraphic contact. The sorted data were then correlated into the mineralogic model layers (Table 6-1). The matrix saturation data are for present-day climate conditions (assuming that the core samples represent present-day conditions). Therefore, the heat capacity values estimated in this report are also for present day climate conditions.

For the rock-matrix property data identified in Table 4-3, the depth to the vitric-zeolitic boundary of the Calico Hills Formation and adjacent bedded tuffs is provided by DTN: MO0004QGFMPICK.000 [DIRS 152554]. The location of the vitric-zeolitic boundary provided by DTN: MO0004QGFMPICK.000 [DIRS 152554] was based on the examination of mineralogic XRD data, borehole geophysics, visual inspection of core and cuttings material, and the difference between the relative humidity and the $105^{\circ} \mathrm{C}$ porosity values. The documentation 
of the criteria used to establish this boundary is in the stratigraphic workbooks (DTNs: GS000108314211.001 [DIRS 162599], GS000308314211.002 [DIRS 158000], and GS000608314211.003 [DIRS 161658]). Based on the information in DTN: MO0004QGFMPICK.000 [DIRS 152554], the matrix property data (DTNs: MO0109HYMXPROP.001 [DIRS 155989], GS980808312242.014 [DIRS 106748], and GS980708312242.010 [DIRS 106752]) were divided into vitric and zeolitic subsets for each layer (Table 6-8).

The criteria based on abundance data, used in Section 6.3 to define the vitric-to-zeolitic transition for the mineralogic model layers, and the criteria used to distinguish vitric and zeolitic matrix properties from the borehole data (DTN: MO0004QGFMPICK.000 [DIRS 152554]), have not been correlated. However, the criteria applied to the two data sets were the best available. In addition, correlating the two criteria would not result in a markedly different vitric-to-zeolitic transition. Therefore, the differences between the two definitions of vitric-to-zeolitic contact are slight, and will have no significant impact on the development of the heat capacity parameter.

The following parameter values were used in Equation 6-22 to evaluate the rock-mass heat capacity over the $25^{\circ} \mathrm{C}$ to $95^{\circ} \mathrm{C}$ temperature interval:

$$
\begin{aligned}
& \phi_{m}=\text { matrix porosity, } \mathrm{m}^{3} / \mathrm{m}^{3}(\text { Table } 6-8) \\
& C_{p, g}=\text { rock-grain heat capacity, } \mathrm{J} / \mathrm{kg}-\mathrm{K} \text { (Table 6-6) } \\
& S_{w}=\text { matrix water saturation, } \mathrm{m}^{3} / \mathrm{m}^{3}(\text { Table } 6-8) \\
& C_{p, w}=\text { heat capacity of water, equal to } 4190 \mathrm{~J} / \mathrm{kg}-\mathrm{K} \text { (as stated in Section 5) } \\
& \rho_{g}=\text { rock-grain density, } \mathrm{kg} / \mathrm{m}^{3}(\text { Table } 6-8) \\
& \rho_{w} \quad=\text { density of water, equal to } 981 \mathrm{~kg} / \mathrm{m}^{3} \text { (as stated in Section 5). }
\end{aligned}
$$

Following the methodology of Nimick and Connolly (1991 [DIRS 100690], pp. 34 to 35), pore water begins boiling off at $95^{\circ} \mathrm{C}$. In the trans-boiling phase $\left(95^{\circ} \mathrm{C}\right.$ to $\left.114^{\circ} \mathrm{C}\right)$, the water saturation decreases linearly, from the initial value given in Table 6-8 to zero, over the $19^{\circ} \mathrm{C}$ temperature range. The linear variation of the saturation $\mathrm{S}_{\mathrm{w}}$ from $\mathrm{S}_{\mathrm{wo}}$ at $368.15 \mathrm{~K}\left(95^{\circ} \mathrm{C}\right)$ to 0 at $387.15 \mathrm{~K}\left(114^{\circ} \mathrm{C}\right)$ is expressed by the following equation:

$$
\mathrm{S}_{\mathrm{w}}=\mathrm{S}_{\mathrm{wo}}(20.376316-0.05263 \mathrm{~T})
$$

where:

$$
\begin{aligned}
& \mathrm{S}_{\mathrm{wo}}=\text { the initial water saturation } \\
& \left.\mathrm{T}=\text { the absolute temperature, } \mathrm{K} \text { (where } \mathrm{K}={ }^{\circ} \mathrm{C}+273.15\right) .
\end{aligned}
$$

The temperature used to calculate $\mathrm{S}_{\mathrm{w}}$ in Equation $6-22$ is $105^{\circ} \mathrm{C}(377.15 \mathrm{~K})$. The temperature of $105^{\circ} \mathrm{C}$ was selected because it is the approximate midpoint or average temperature over which boiling occurs $\left(95^{\circ} \mathrm{C}\right.$ to $\left.114^{\circ} \mathrm{C}\right)$.

As illustrated in Figure 6-9 (reproduced from the Thermal Testing Measurements Report (BSC 2004 [DIRS 169900], Figure 6.3.2.3-2)), results from the Drift Scale Test neutron logging and temperature measurements provide supporting evidence that the pore water vaporizes over a temperature range starting at approximately $95^{\circ} \mathrm{C}$. 
During the trans-boiling stage, a "correction" is added to the calculation of thermal capacity that accounts for the "heat capacity of boiling" (Nimick and Connolly 1991 [DIRS 100690], p. 37). Documentation of the process and calculation needed to apply this correction to the rock-mass heat capacity values is provided in Input Parameters for Thermal Modeling Using Conduction-Only Models (CRWMS M\&O 2000 [DIRS 153199], p. 11). Equation 7 from that report is reproduced here as Equation 6-23. Nimick and Connolly (1991 [DIRS 100690], p. 37) used the same temperature interval $\left(95^{\circ} \mathrm{C}\right.$ to $\left.114^{\circ} \mathrm{C}\right)$. Even though they state that they used a $\Delta T$ of $20^{\circ} \mathrm{C}$, a close examination of their equation (Equation 11) (Nimick and Connolly 1991 [DIRS 100690], p. 34) suggests that they actually used a $\Delta T$ of $19^{\circ} \mathrm{C}$, which is what is used in Equation 6-23.

$$
\begin{gathered}
C_{p, r m}=\left(C_{p, r m}\right)_{T=105}+\frac{\rho_{w}\left(1-\phi_{L}\right) \phi_{m} S_{w}}{\rho_{r m}}\left[\frac{H_{f g}}{\Delta T}\right] \\
C_{p, r m}=\left(C_{p, r m}\right)_{T=105}+\frac{\rho_{w}\left(1-\phi_{L}\right) \phi_{m} S_{w}}{\rho_{g}\left(1-\phi_{L}\right)\left(1-\phi_{m}\right)+\left(1-\phi_{L}\right) \phi_{m} S_{w} \rho_{w}}\left[\frac{H_{f g}}{\Delta T}\right] \\
=\left(C_{p, r m}\right)_{T=105}+\frac{\rho_{w} \phi_{m} S_{w}}{\rho_{g}\left(1-\phi_{m}\right)+\phi_{m} S_{w} \rho_{w}}\left[\frac{H_{f g}}{\Delta T}\right]
\end{gathered}
$$

As can be seen from Equation 6-24, the rock-mass heat capacity for the trans-boiling stage is

\begin{tabular}{|c|c|c|c|c|c|c|c|c|c|}
\hline \multirow[b]{2}{*}{$\begin{array}{l}\text { Mineralogic } \\
\text { Model Units }\end{array}$} & \multicolumn{3}{|c|}{ Matrix Saturation } & \multicolumn{3}{|c|}{ Grain Density } & \multicolumn{3}{|c|}{ Matrix Porosity } \\
\hline & Average & $\begin{array}{l}\text { Standard } \\
\text { Deviation }\end{array}$ & $\begin{array}{c}\text { Number } \\
\text { of } \\
\text { Analyses }\end{array}$ & Average $^{a}$ & $\begin{array}{l}\text { Standard } \\
\text { Deviation }\end{array}$ & $\begin{array}{c}\text { Number } \\
\text { of } \\
\text { Analyses }\end{array}$ & Average & $\begin{array}{l}\text { Standard } \\
\text { Deviation }\end{array}$ & $\begin{array}{c}\begin{array}{c}\text { Number } \\
\text { of }\end{array} \\
\text { Analyses } \\
\end{array}$ \\
\hline Tpc_un & 0.711 & 0.196 & 954 & 2.51 & 0.03 & 954 & 0.119 & 0.071 & 954 \\
\hline $\begin{array}{l}\text { Tpcpv3- } \\
\text { Tpcpv2 }\end{array}$ & 0.945 & 0.119 & 72 & 2.43 & 0.07 & 72 & 0.270 & 0.089 & 72 \\
\hline $\mathrm{PTn}^{\mathrm{b}}$ & 0.463 & 0.197 & 654 & 2.32 & 0.12 & 656 & 0.443 & 0.106 & 656 \\
\hline Tptrv1 & 0.733 & 0.292 & 19 & 2.47 & 0.03 & 19 & 0.053 & 0.056 & 19 \\
\hline $\begin{array}{l}\text { Tptrn-Tptrl- } \\
\text { Tptf }\end{array}$ & 0.525 & 0.148 & 508 & 2.54 & 0.04 & 508 & 0.142 & 0.045 & 508 \\
\hline Tptpul & 0.744 & 0.142 & 529 & 2.50 & 0.03 & 529 & 0.143 & 0.035 & 529 \\
\hline Tptpmn & 0.856 & 0.113 & 384 & 2.52 & 0.03 & 384 & 0.105 & 0.023 & 384 \\
\hline Tptpll & 0.794 & 0.126 & 694 & 2.54 & 0.03 & 694 & 0.127 & 0.034 & 694 \\
\hline Tptpln & 0.866 & 0.089 & 425 & 2.54 & 0.04 & 425 & 0.095 & 0.028 & 425 \\
\hline Tptpv3 & 0.881 & 0.117 & 178 & 2.38 & 0.04 & 182 & 0.038 & 0.036 & 171 \\
\hline Tptpv2 & 0.797 & 0.196 & 51 & 2.32 & 0.08 & 51 & 0.184 & 0.095 & 48 \\
\hline Tptpv1-Tpbt1 & 0.651 & 0.352 & 122 & 2.26 & 0.09 & 123 & 0.262 & 0.072 & 110 \\
\hline
\end{tabular}
also independent of the lithophysal porosity.

Table 6-8. Averaged Rock Matrix Properties for Lithostratigraphic Units 
Table 6-8. Averaged Rock Matrix Properties for Lithostratigraphic Units (Continued)

\begin{tabular}{|c|c|c|c|c|c|c|c|c|c|}
\hline \multirow[b]{2}{*}{$\begin{array}{l}\text { Mineralogic } \\
\text { Model Units }\end{array}$} & \multicolumn{3}{|c|}{ Matrix Saturation } & \multicolumn{3}{|c|}{ Grain Density } & \multicolumn{3}{|c|}{ Matrix Porosity } \\
\hline & Average & $\begin{array}{l}\text { Standard } \\
\text { Deviation }\end{array}$ & $\begin{array}{c}\text { Number } \\
\text { of } \\
\text { Analyses }\end{array}$ & Average $^{a}$ & $\begin{array}{l}\text { Standard } \\
\text { Deviation }\end{array}$ & $\begin{array}{c}\text { Number } \\
\text { of } \\
\text { Analyses }\end{array}$ & Average & $\begin{array}{l}\text { Standard } \\
\text { Deviation }\end{array}$ & $\begin{array}{c}\text { Number } \\
\text { of } \\
\text { Analyses }\end{array}$ \\
\hline Tac1 & 0.901 & 0.192 & 802 & 2.27 & 0.09 & 803 & 0.301 & 0.063 & 561 \\
\hline Tac2 & 0.901 & 0.192 & 802 & 2.27 & 0.09 & 803 & 0.301 & 0.063 & 561 \\
\hline Tac3 & 0.901 & 0.192 & 802 & 2.27 & 0.09 & 803 & 0.301 & 0.063 & 561 \\
\hline Tac4 & 0.901 & 0.192 & 802 & 2.27 & 0.09 & 803 & 0.301 & 0.063 & 561 \\
\hline Tacbt & 0.987 & 0.041 & 111 & 2.37 & 0.12 & 111 & 0.234 & 0.071 & 111 \\
\hline Tcpuv & 0.952 & 0.056 & 80 & 2.35 & 0.09 & 80 & 0.294 & 0.065 & 80 \\
\hline $\begin{array}{l}\text { Tcpuc- } \\
\text { Tcpmd-Tcplc }^{\mathrm{e}}\end{array}$ & 0.638 & 0.327 & 415 & 2.55 & 0.07 & 415 & 0.254 & 0.073 & 415 \\
\hline $\begin{array}{l}\text { Tcplv-Tcpbt- } \\
\text { Tcbuv }^{\dagger}\end{array}$ & 0.814 & 0.253 & 545 & 2.39 & 0.11 & 545 & 0.256 & 0.098 & 545 \\
\hline $\begin{array}{l}\text { Tcbuc- } \\
\text { Tcbmd-Tcblc }^{\mathrm{g}}\end{array}$ & 0.981 & 0.077 & 194 & 2.56 & 0.04 & 194 & 0.120 & 0.052 & 194 \\
\hline $\begin{array}{l}\text { Tcblv-Tcbbt- } \\
\text { Tctuv }{ }^{\mathrm{h}}\end{array}$ & 1.026 & 0.053 & 80 & 2.35 & 0.06 & 80 & 0.209 & 0.055 & 80 \\
\hline $\begin{array}{l}\text { Tctuc-Tctmd- } \\
\text { Tctllc }^{i}\end{array}$ & 1.006 & 0.032 & 42 & 2.39 & 0.06 & 42 & 0.317 & 0.067 & 42 \\
\hline Tctlv-Tctbt $^{\mathrm{d}}$ & 1.0 & & & 2.39 & & & 0.250 & & \\
\hline Tund $^{d}$ & 1.0 & & & 2.39 & & & 0.250 & & \\
\hline \multicolumn{10}{|l|}{ Vitric $^{c}$} \\
\hline Tptpv2 & 0.784 & 0.201 & 46 & 2.32 & 0.08 & 46 & 0.188 & 0.096 & 45 \\
\hline Tptpv1-Tpbt1 & 0.399 & 0.226 & 71 & 2.27 & 0.07 & 71 & 0.268 & 0.073 & 71 \\
\hline Tac1 & 0.640 & 0.292 & 160 & 2.24 & 0.09 & 160 & 0.341 & 0.038 & 160 \\
\hline Tac2 & 0.640 & 0.292 & 160 & 2.24 & 0.09 & 160 & 0.341 & 0.038 & 160 \\
\hline Tac3 & 0.640 & 0.292 & 160 & 2.24 & 0.09 & 160 & 0.341 & 0.038 & 160 \\
\hline Tac4 & 0.640 & 0.292 & 160 & 2.24 & 0.09 & 160 & 0.341 & 0.038 & 160 \\
\hline Tacbt & 0.939 & $\mathrm{~N} / \mathrm{A}$ & 1 & 2.35 & $\mathrm{~N} / \mathrm{A}$ & 1 & 0.418 & $\mathrm{~N} / \mathrm{A}$ & 1 \\
\hline \multicolumn{10}{|l|}{ Zeolitic $^{c}$} \\
\hline Tptpv2 & 0.923 & 0.077 & 5 & 2.28 & 0.11 & 5 & 0.120 & 0.032 & 3 \\
\hline $\begin{array}{l}\text { Tptpv1- } \\
\text { Tpbt1 }\end{array}$ & 1.002 & 0.109 & 51 & 2.25 & 0.10 & 52 & 0.252 & 0.070 & 39 \\
\hline Tac1 & 0.966 & 0.061 & 642 & 2.28 & 0.09 & 643 & 0.285 & 0.064 & 401 \\
\hline Tac2 & 0.966 & 0.061 & 642 & 2.28 & 0.09 & 643 & 0.285 & 0.064 & 401 \\
\hline
\end{tabular}


Table 6-8. Averaged Rock Matrix Properties for Lithostratigraphic Units (Continued)

\begin{tabular}{|c|c|c|c|c|c|c|c|c|c|}
\hline \multirow[b]{2}{*}{$\begin{array}{l}\text { Mineralogic } \\
\text { Model Units }\end{array}$} & \multicolumn{3}{|c|}{ Matrix Saturation } & \multicolumn{3}{|c|}{ Grain Density } & \multicolumn{3}{|c|}{ Matrix Porosity } \\
\hline & Average & $\begin{array}{l}\text { Standard } \\
\text { Deviation }\end{array}$ & $\begin{array}{c}\text { Number } \\
\text { of } \\
\text { Analyses }\end{array}$ & Average $^{\mathrm{a}}$ & $\begin{array}{l}\text { Standard } \\
\text { Deviation }\end{array}$ & $\begin{array}{c}\text { Number } \\
\text { of } \\
\text { Analyses }\end{array}$ & Average & $\begin{array}{l}\text { Standard } \\
\text { Deviation }\end{array}$ & $\begin{array}{c}\text { Number } \\
\text { of } \\
\text { Analyses }\end{array}$ \\
\hline Tac3 & 0.966 & 0.061 & 642 & 2.28 & 0.09 & 643 & 0.285 & 0.064 & 401 \\
\hline Tac4 & 0.966 & 0.061 & 642 & 2.28 & 0.09 & 643 & 0.285 & 0.064 & 401 \\
\hline Tacbt & 0.988 & 0.041 & 110 & 2.37 & 0.12 & 110 & 0.232 & 0.069 & 110 \\
\hline
\end{tabular}

Source of data presented in Table 6-8: DTNs: MO0109HYMXPROP.001 [DIRS 155989], GS980808312242.014 [DIRS 106748], and GS980708312242.010 [DIRS 106752]. See also Table 4-3.

The data in this table are from output DTN: SN0409T0510902.004, Excel file Hydraulic Properties-final.xIs, sheet "Summary Values." Columns C, D, and E in "Summary Values" contain the data for Matrix Saturation (Columns 2, 3, and 4) in Table 6-8. Columns G, H, and I in "Summary Values" contain the data for Grain Density (Columns 5, 6, and 7) in Table 6-8. Columns K, L, and M in "Summary Values" contain the data for Matrix Porosity (Columns 8, 9, and 10) in Table 6-8.

${ }^{a}$ Units of grain density are $\mathrm{g} / \mathrm{cm}^{3}$.

b PTn = Tpcpv1, Tpbt4, Tpy, Tpbt3, Tpp, Tpbt2, Tptrv3, Tptrv2.

${ }^{c}$ The definitions of the vitric and zeolitic lithostratigraphic layers are presented in Section 6.3.

${ }^{d}$ For units Tctlv-Tctbt and Tund, values for matrix saturation, grain density, and matrix porosity are based on data from neighboring layers.

e Tcpuc-Tcpmd-Tcplc is the same as unit Tcpuc-Tcplc in the mineralogic model. The mineralogic model name was expanded to indicate that this unit also includes the stratigraphic unit Tcpmd.

$f$ Tcplv-Tcpbt-Tcbuv is the same as unit Tcplv-Tcbuv in the mineralogic model. The mineralogic model name was expanded to indicate that this unit also includes the stratigraphic unit Tcpbt.

${ }^{g}$ Tcbuc-Tcbmd-Tcblc is the same as unit Tcbuc-Tcblc in the mineralogic model. The mineralogic model name was expanded to indicate that this unit also includes the stratigraphic unit Tcbmd.

${ }^{\mathrm{h}}$ Tcblv-Tcbbt-Tctuv is the same as unit Tcblv-Tctuv in the mineralogic model. The mineralogic model name was expanded to indicate that this unit also includes the stratigraphic unit Tcbbt.

i Tctuc-Tctmd-Tctlc is the same as unit Tctuc-Tctlc in the mineralogic model. The mineralogic model name was expanded to indicate that this unit also includes the stratigraphic unit Tctmd.

j Tpc_un is the same as unit Alluvium-Tpc_un in the mineralogic model.

N/A = Not available. The standard deviation cannot be calculated with only one value.

In this analysis,

$C_{p, r m}$ is the average rock-mass heat capacity for the $95^{\circ} \mathrm{C}$ to $114^{\circ} \mathrm{C}$ temperature range.

$\left(C_{p, r m}\right)_{T=105}$ is the rock-mass heat capacity at $105^{\circ} \mathrm{C}$. Equation $6-20$ is evaluated at the midpoint of the $95^{\circ} \mathrm{C}$ to $114^{\circ} \mathrm{C}$ temperature range.

$C_{p, w}$ is the heat capacity of water. A value of $4215.9 \mathrm{~J} / \mathrm{kg}-\mathrm{K}$ (Lide 2002 [DIRS 160832], p. 6-3) was used in Equation 6-20.

$\rho_{w}$ is the density of water: $958.4 \mathrm{~kg} / \mathrm{m}^{3}$ (at $100^{\circ} \mathrm{C}$ ), from the CRC Handbook of Chemistry and Physics (Lide 2002 [DIRS 160832], p. 6-3).

$\phi_{m}$ is the matrix porosity (Table 6-8). 


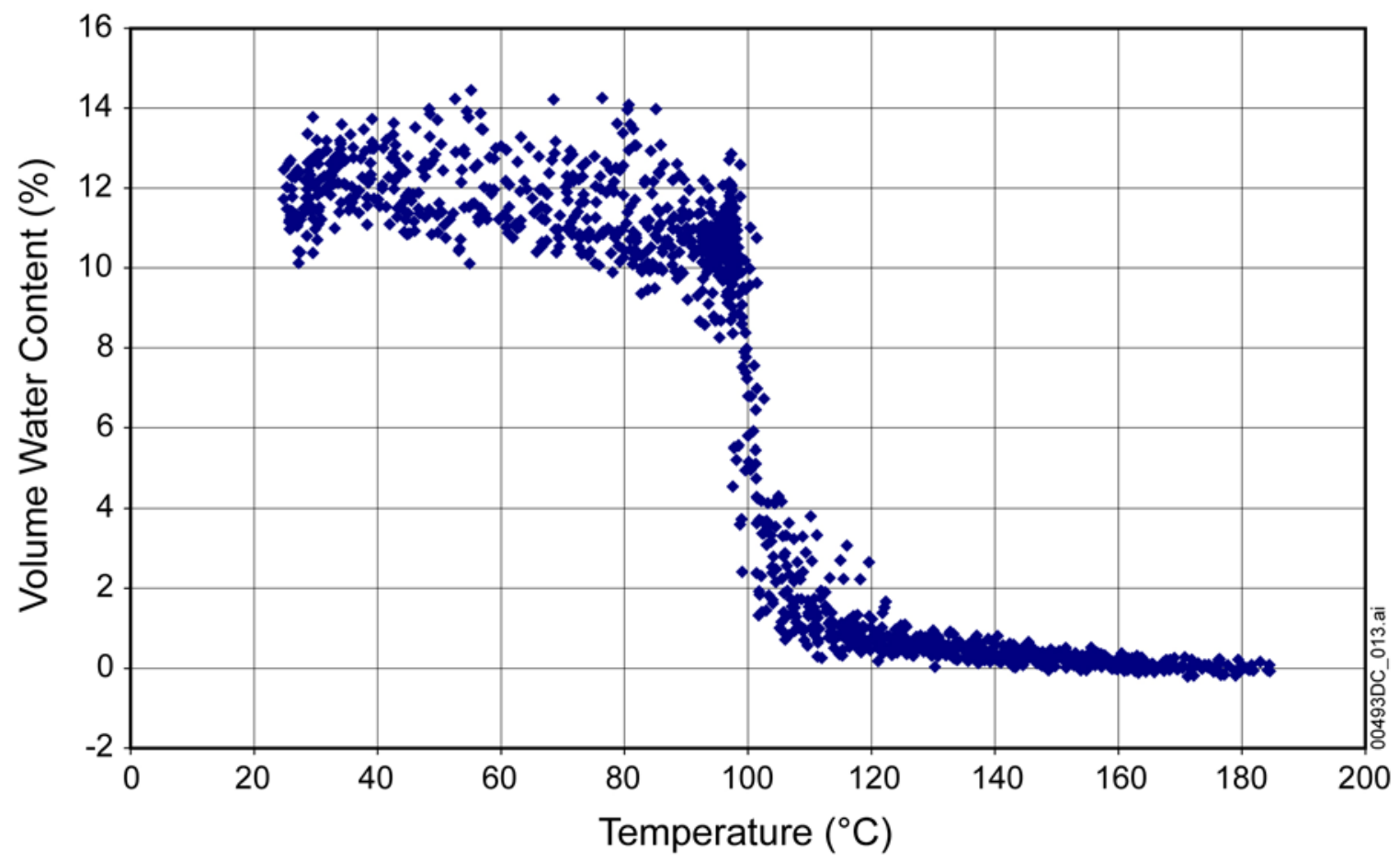

Source: Thermal Testing Measurements Report (BSC 2004 [DIRS 169900], Figure 6.3.2.3-2).

Figure 6-9. Rock Moisture Content as a Function of Temperature as Measured from Neutron Logging of Boreholes 79 and 80 During the Drift Scale Test Heating Phase

$S_{w}$ is the degree of water saturation from Equation 6-22, evaluated at $\mathrm{T}=105^{\circ} \mathrm{C}$.

$\rho_{r m}$ is the bulk density of the rock mass, evaluated from the expression in the denominator of Equation 6-20.

$H_{f g}$ is the enthalpy of water at $\mathrm{T}=100^{\circ} \mathrm{C}, \mathrm{J} / \mathrm{kg}$ taken to be $2256806 \mathrm{~J} / \mathrm{kg}$, from the $C R C$ Handbook of Chemistry and Physics (Lide 2002 [DIRS 160832], p. 6-3).

$\Delta T$ is the temperature interval for boiling $\left(19^{\circ} \mathrm{C}\right)$.

For temperatures above $114^{\circ} \mathrm{C}$, the water is completely boiled off; therefore, the matrix saturation is $S_{\mathrm{w}}=0$. In this case, Equation 6-19 reduces to:

$$
\left(\rho C_{p}\right)_{r m}=\rho_{g}\left(1-\phi_{m}\right)\left(1-\phi_{L}\right) C_{p, g}
$$

Substituting Equation 6-25 into Equation 6-20 gives the result that the rock-mass heat capacity is equal to the rock-grain heat capacity.

$$
C_{p, r m}=\frac{\left(\rho C_{p}\right)_{r m}}{\rho_{g}\left(1-\phi_{L}\right)\left(1-\phi_{m}\right)}=C_{p, g}
$$


Using the rock-grain heat capacities given in Table 6-6, matrix properties in Table 6-8, and the physical properties of water from the CRC Handbook of Chemistry and Physics (Lide 2002 [DIRS 160832], pp. 6-3 and 6-4), it is a straightforward calculation to determine the rock-mass heat capacity. This was done for three temperature ranges: preboiling $\left(25^{\circ} \mathrm{C}\right.$ to $\left.95^{\circ} \mathrm{C}\right)$, trans-boiling $\left(95^{\circ} \mathrm{C}\right.$ to $\left.114^{\circ} \mathrm{C}\right)$, and postboiling $\left(114^{\circ} \mathrm{C}\right.$ to $\left.325^{\circ} \mathrm{C}\right)$. The results of these calculations are presented in Table 6-9.

Table 6-9. Rock-Mass Heat Capacities for Lithostratigraphic Units

\begin{tabular}{|c|c|c|c|c|c|c|}
\hline $\begin{array}{c}\text { Mineralogic } \\
\text { Model Unit }\end{array}$ & $\begin{array}{c}\text { Average } \\
\text { Rock-Mass } \\
\text { Heat Capacity } \\
\mathrm{T}=25^{\circ} \mathrm{C}-95^{\circ} \mathrm{C} \\
\mathrm{J} / \mathrm{kg}-\mathrm{K}\end{array}$ & $\begin{array}{c}\text { Standard } \\
\text { Deviation of } \\
\text { Rock-Mass } \\
\text { Heat Capacity } \\
\mathrm{T}=25^{\circ} \mathrm{C}-95^{\circ} \mathrm{C} \\
\mathrm{J} / \mathrm{kg}-\mathrm{K} \\
\end{array}$ & $\begin{array}{c}\text { Average } \\
\text { Rock-Mass } \\
\text { Heat Capacity } \\
\mathrm{T}=95^{\circ} \mathrm{C}-114^{\circ} \mathrm{C} \\
\mathrm{J} / \mathrm{kg}-\mathrm{K} \\
\end{array}$ & \begin{tabular}{|c} 
Standard \\
Deviation of \\
Rock-Mass \\
Heat Capacity \\
$\mathrm{T}=95^{\circ} \mathrm{C}-114^{\circ} \mathrm{C}$ \\
$\mathrm{J} / \mathrm{kg}-\mathrm{K}$ \\
\end{tabular} & $\begin{array}{c}\text { Average } \\
\text { Rock-Mass } \\
\text { Heat Capacity } \\
\mathrm{T}=114^{\circ} \mathrm{C}-325^{\circ} \mathrm{C} \\
\mathrm{J} / \mathrm{kg}-\mathrm{K} \\
\end{array}$ & $\begin{array}{c}\text { Standard } \\
\text { Deviation of } \\
\text { Rock-Mass } \\
\text { Heat Capacity } \\
\mathrm{T}=114^{\circ} \mathrm{C}-325^{\circ} \mathrm{C} \\
\mathrm{J} / \mathrm{kg}-\mathrm{K} \\
\end{array}$ \\
\hline Tpc_un ${ }^{\mathrm{h}}$ & $9.1 \mathrm{E}+02$ & $3 . E+02$ & $3.0 \mathrm{E}+03$ & $9 . \mathrm{E}+02$ & $9.9 \mathrm{E}+02$ & $3 . E+02$ \\
\hline Tpсpv3-Tpсpv2 & $1.2 \mathrm{E}+03$ & 4.E+02 & $8.4 \mathrm{E}+03$ & $2 . E+03$ & $1.0 \mathrm{E}+03$ & $3 . E+02$ \\
\hline $\mathrm{PTn}^{\mathrm{a}}$ & $1.3 \mathrm{E}+03$ & $4 . E+02$ & $9.1 \mathrm{E}+03$ & $3 . E+03$ & $1.0 \mathrm{E}+03$ & $3 . E+02$ \\
\hline Tptrv1 & $8.9 \mathrm{E}+02$ & $3 . E+02$ & $1.8 \mathrm{E}+03$ & $5 . E+02$ & $9.9 \mathrm{E}+02$ & $3 . E+02$ \\
\hline Tptrn-Tptrl-Tptf & $8.9 \mathrm{E}+02$ & $3 . E+02$ & $2.7 \mathrm{E}+03$ & $8 . E+02$ & $9.9 \mathrm{E}+02$ & $3 . E+02$ \\
\hline Tptpul & $9.4 \mathrm{E}+02$ & $3 . E+02$ & $3.6 \mathrm{E}+03$ & $1 . E+03$ & $9.9 \mathrm{E}+02$ & $3 . E+02$ \\
\hline Tptpmn & $9.1 \mathrm{E}+02$ & $3 . E+02$ & $3.0 \mathrm{E}+03$ & $9 . E+02$ & $9.9 \mathrm{E}+02$ & $3 . E+02$ \\
\hline Tptpll & $9.3 \mathrm{E}+02$ & $3 . E+02$ & $3.3 \mathrm{E}+03$ & 1. $E+03$ & $9.9 \mathrm{E}+02$ & $3 . E+02$ \\
\hline Tptpln & $9.0 \mathrm{E}+02$ & $3 . E+02$ & $2.8 \mathrm{E}+03$ & $8 . E+02$ & $9.9 \mathrm{E}+02$ & $3 . E+02$ \\
\hline Tptpv3 & $9.1 \mathrm{E}+02$ & $3 . E+02$ & $1.7 \mathrm{E}+03$ & $5 . \mathrm{E}+02$ & $1.0 \mathrm{E}+03$ & $3 . E+02$ \\
\hline Tptpv2 & $1.1 \mathrm{E}+03$ & $3 . E+02$ & $5.1 \mathrm{E}+03$ & 1. $E+03$ & $1.0 \mathrm{E}+03$ & $3 . E+02$ \\
\hline Tptpv1-Tpbt1 & $1.2 \mathrm{E}+03$ & 4.E+02 & $6.4 \mathrm{E}+03$ & $2 . E+03$ & $1.1 \mathrm{E}+03$ & $3 . E+02$ \\
\hline Tac4 & $1.4 \mathrm{E}+03$ & $4 . E+02$ & $9.8 \mathrm{E}+03$ & $3 . E+03$ & $1.1 \mathrm{E}+03$ & $3 . E+02$ \\
\hline Tac3 & $1.4 \mathrm{E}+03$ & 4.E+02 & $9.8 \mathrm{E}+03$ & $3 . E+03$ & $1.1 \mathrm{E}+03$ & $3 . E+02$ \\
\hline Tac2 & $1.4 \mathrm{E}+03$ & $4 . E+02$ & $9.8 \mathrm{E}+03$ & $3 . E+03$ & $1.1 \mathrm{E}+03$ & $3 . E+02$ \\
\hline Tac1 & $1.4 \mathrm{E}+03$ & $4 . E+02$ & $9.8 \mathrm{E}+03$ & $3 . E+03$ & $1.1 \mathrm{E}+03$ & $3 . E+02$ \\
\hline Tacbt & $1.2 \mathrm{E}+03$ & $4 . E+02$ & $7.6 \mathrm{E}+03$ & $2 . E+03$ & $1.1 \mathrm{E}+03$ & $3 . E+02$ \\
\hline Tcpuv & $1.4 \mathrm{E}+03$ & $4 . E+02$ & $9.7 \mathrm{E}+03$ & $3 . E+03$ & $1.1 \mathrm{E}+03$ & $3 . E+02$ \\
\hline $\begin{array}{l}\text { Tcpuc-Tcpmd- } \\
\text { Tcplc }^{\text {c }}\end{array}$ & $1.0 \mathrm{E}+03$ & $3 . E+02$ & $5.4 \mathrm{E}+03$ & $2 . E+03$ & $9.9 \mathrm{E}+02$ & $3 . E+02$ \\
\hline \begin{tabular}{|l} 
Tcplv-Tcpbt- \\
Tcbuv $^{\mathrm{d}}$
\end{tabular} & $1.3 \mathrm{E}+03$ & 4. E+02 & $7.2 \mathrm{E}+03$ & 2. $E+03$ & $1.2 \mathrm{E}+03$ & $3 . E+02$ \\
\hline $\begin{array}{l}\text { Tcbuc-Tcbmd- } \\
\text { Tcblc }^{\text {e }}\end{array}$ & $9.5 \mathrm{E}+02$ & $3 . E+02$ & $3.7 \mathrm{E}+03$ & 1. $E+03$ & $9.9 \mathrm{E}+02$ & $3 . E+02$ \\
\hline $\begin{array}{l}\text { Tcblv-Tcbbt- } \\
\text { Tctuv }^{{ }^{f}}\end{array}$ & $1.2 \mathrm{E}+03$ & 4. $E+02$ & $7.1 \mathrm{E}+03$ & 2. $E+03$ & $1.1 \mathrm{E}+03$ & $3 . E+02$ \\
\hline $\begin{array}{l}\text { Tctuc-Tctmd- } \\
\text { Tctlc }^{\text {g }}\end{array}$ & 1.3E+03 & 4. $E+02$ & $1.1 \mathrm{E}+04$ & $3 . E+03$ & $9.9 \mathrm{E}+02$ & $3 . E+02$ \\
\hline Tctlv-Tctbt & $1.2 \mathrm{E}+03$ & $4 . E+02$ & $8.2 \mathrm{E}+03$ & $2 . E+03$ & $9.9 \mathrm{E}+02$ & $3 . E+02$ \\
\hline Tund & $1.2 \mathrm{E}+03$ & $4 . E+02$ & $8.2 E+03$ & $2 . E+03$ & $1.0 \mathrm{E}+03$ & $3 . E+02$ \\
\hline
\end{tabular}


Table 6-9. Rock-Mass Heat Capacities for Lithostratigraphic Units (Continued)

\begin{tabular}{|c|c|c|c|c|c|c|}
\hline $\begin{array}{c}\text { Mineralogic } \\
\text { Model Unit }\end{array}$ & $\begin{array}{c}\text { Average } \\
\text { Rock-Mass } \\
\text { Heat Capacity } \\
\mathrm{T}=25^{\circ} \mathrm{C}-95^{\circ} \mathrm{C} \\
\mathrm{J} / \mathrm{kg}-\mathrm{K}\end{array}$ & $\begin{array}{c}\text { Standard } \\
\text { Deviation of } \\
\text { Rock-Mass } \\
\text { Heat Capacity } \\
\mathrm{T}=25^{\circ} \mathrm{C}-95^{\circ} \mathrm{C} \\
\mathrm{J} / \mathrm{kg}-\mathrm{K}\end{array}$ & $\begin{array}{c}\text { Average } \\
\text { Rock-Mass } \\
\text { Heat Capacity } \\
\mathrm{T}=95^{\circ} \mathrm{C}-114^{\circ} \mathrm{C} \\
\mathrm{J} / \mathrm{kg}-\mathrm{K}\end{array}$ & $\begin{array}{c}\text { Standard } \\
\text { Deviation of } \\
\text { Rock-Mass } \\
\text { Heat Capacity } \\
\mathrm{T}=95^{\circ} \mathrm{C}-114^{\circ} \mathrm{C} \\
\mathrm{J} / \mathrm{kg}-\mathrm{K}\end{array}$ & $\begin{array}{c}\text { Average } \\
\text { Rock-Mass } \\
\text { Heat Capacity } \\
\mathrm{T}=114^{\circ} \mathrm{C}-325^{\circ} \mathrm{C} \\
\mathrm{J} / \mathrm{kg}-\mathrm{K}\end{array}$ & $\begin{array}{c}\text { Standard } \\
\text { Deviation of } \\
\text { Rock-Mass } \\
\text { Heat Capacity } \\
\mathrm{T}=114^{\circ} \mathrm{C}-325^{\circ} \mathrm{C} \\
\mathrm{J} / \mathrm{kg}-\mathrm{K}\end{array}$ \\
\hline \multicolumn{7}{|l|}{ Vitric ${ }^{\mathrm{b}}$} \\
\hline Tptpv2 & $1.1 \mathrm{E}+03$ & 3.E+02 & $5.1 \mathrm{E}+03$ & 1. $E+03$ & $1.0 \mathrm{E}+03$ & $3 . E+02$ \\
\hline Tptpv1-Tpbt1 & $1.0 \mathrm{E}+03$ & 3.E+02 & $4.3 \mathrm{E}+03$ & 1.E+03 & $1.0 \mathrm{E}+03$ & 3.E+02 \\
\hline Tac4 & $1.3 \mathrm{E}+03$ & 4.E+02 & $8.5 \mathrm{E}+03$ & $2 . E+03$ & $1.0 \mathrm{E}+03$ & $3 . E+02$ \\
\hline Tac3 & $1.3 E+03$ & 4. $E+02$ & $8.5 E+03$ & 2. $E+03$ & $1.0 \mathrm{E}+03$ & 3.E+02 \\
\hline Tac2 & $1.3 \mathrm{E}+03$ & 4.E+02 & $8.5 \mathrm{E}+03$ & $2 . E+03$ & $1.0 \mathrm{E}+03$ & $3 . E+02$ \\
\hline Tac1 & $1.3 \mathrm{E}+03$ & $4 . E+02$ & $8.5 \mathrm{E}+03$ & $2 . E+03$ & $1.0 \mathrm{E}+03$ & $3 . E+02$ \\
\hline Tacbt & $1.6 \mathrm{E}+03$ & $5 . E+02$ & $1.5 \mathrm{E}+04$ & $4 . E+03$ & $1.0 \mathrm{E}+03$ & $3 . E+02$ \\
\hline \multicolumn{7}{|l|}{ Zeolitic $^{\text {b }}$} \\
\hline Tptpv2 & $1.1 \mathrm{E}+03$ & $3 . E+02$ & $3.9 \mathrm{E}+03$ & 1. $E+03$ & $1.1 \mathrm{E}+03$ & $3 . E+02$ \\
\hline Tptpv1-Tpbt1 & $1.4 \mathrm{E}+03$ & $4 . E+02$ & $8.8 \mathrm{E}+03$ & 3.E+03 & $1.2 \mathrm{E}+03$ & 4.E+02 \\
\hline Tac4 & $1.4 \mathrm{E}+03$ & 4.E+02 & $9.7 \mathrm{E}+03$ & $3 . E+03$ & $1.2 \mathrm{E}+03$ & 4.E+02 \\
\hline Tac3 & $1.4 \mathrm{E}+03$ & $4 . E+02$ & $9.6 \mathrm{E}+03$ & $3 . E+03$ & $1.2 \mathrm{E}+03$ & $3 . E+02$ \\
\hline Tac2 & $1.4 \mathrm{E}+03$ & 4.E+02 & $9.6 \mathrm{E}+03$ & 3.E+03 & $1.2 \mathrm{E}+03$ & 3.E+02 \\
\hline Tac1 & $1.4 \mathrm{E}+03$ & 4.E+02 & $9.6 \mathrm{E}+03$ & 3.E+03 & $1.2 \mathrm{E}+03$ & $3 . E+02$ \\
\hline Tacbt & $1.3 E+03$ & $4 . E+02$ & $7.5 E+03$ & 2. $E+03$ & $1.1 \mathrm{E}+03$ & 3.E+02 \\
\hline
\end{tabular}

The data in this table are from output DTN: SN0307T0510902.003, Excel file rock_mass_heat_capacity.xIs. Sheet "Cp-rm 25-94" (Column P) of the Excel file contains the data for Rock-Mass Heat Capacity (Column 2) in Table 6-9. Sheet "Cp-rm 95-114" (Column T) contains the data for Rock-Mass Heat Capacity (Column 4) in Table 6-9. Sheet "Cp-rm 115-325" (Column P) contains the data for Rock-Mass Heat Capacity (Column 6) in Table 6-9.

NOTE: The values for rock-mass heat capacity given in this table are only valid to two significant figures, and are presented in scientific notation to prevent use of the values beyond the intended precision. The influence of the uncertainty of other properties (porosities, densities, and saturations) has not been accounted for explicitly in the rock-mass heat capacity values given in this table. The standard deviation values assigned to each model layer in this table are approximately 30 percent of the average values. Thirty percent of the mean was selected as the uncertainty associated with the rock-mass heat capacity values. The selection was based on the standard deviations calculated for the rock-grain heat capacities.

${ }^{a}$ PTn = Tpcpv1, Tpbt4, Tpy, Tpbt3, Tpp, Tpbt2, Tptrv3, Tptrv2.

${ }^{\mathrm{b}}$ he definitions of the vitric and zeolitic lithostratigraphic layers are presented in Section 6.3.

${ }^{c}$ cpuc-Tcpmd-Tcplc is the same as unit Tcpuc-Tcplc in the mineralogic model. The mineralogic model name was expanded to indicate that this unit also includes the stratigraphic unit Tcpmd.

${ }^{d}$ cplv-Tcpbt-Tcbuv is the same as unit Tcplv-Tcbuv in the mineralogic model. The mineralogic model name was expanded to indicate that this unit also includes the stratigraphic unit Tcpbt.

e Tcbuc-Tcbmd-Tcblc is the same as unit Tcbuc-Tcblc in the mineralogic model. The mineralogic model name was expanded to indicate that this unit also includes the stratigraphic unit Tcbmd.

${ }^{f}$ cblv-Tcbbt-Tctuv is the same as unit Tcblv-Tctuv in the mineralogic model. The mineralogic model name was expanded to indicate that this unit also includes the stratigraphic unit Tcbbt.

${ }^{g}$ ctuc-Tctmd-Tctlc is the same as unit Tctuc-Tctlc in the mineralogic model. The mineralogic model name was expanded to indicate that this unit also includes the stratigraphic unit Tctmd.

$\mathrm{h}$ Tpc_un is the same as unit Alluvium-Tpc_un in the mineralogic model. 


\section{CONCLUSIONS}

\subsection{SUMMARY}

Average and standard deviations of rock-grain and rock-mass heat capacity have been calculated, using Kopp's Law in conjunction with the mineral summation method, for the temperature ranges of $25^{\circ} \mathrm{C}$ to $95^{\circ} \mathrm{C}, 95^{\circ} \mathrm{C}$ to $114^{\circ} \mathrm{C}$, and $114^{\circ} \mathrm{C}$ to $325^{\circ} \mathrm{C}$. In addition, the rock-grain heat capacities for the temperature range of $25^{\circ} \mathrm{C}$ to $325^{\circ} \mathrm{C}$ have been compiled. The choice of the mineral summation method was based on the availability of the necessary input data and the adequacy of the results for their intended use. Inputs to this analysis consist of mineral abundance, mineral heat capacity, rock-matrix properties, lithostratigraphic contacts, and physical properties of water. The results of this analysis are found in the output DTNs: SN0307T0510902.003 and SN0409T0510902.004. DTN: SN0307T0510902.003 gives the calculated values of the rock-grain and rock-mass heat capacity. DTN: SN0409T0510902.004 gives the heat capacities and the molecular weights of the minerals used to estimate the rock-grain heat capacity, as well as the averaged properties (water saturation, grain [particle] density and matrix porosity) for each layer (see Table 6-8). Results of the analysis indicate that the rock-grain and rock-mass heat capacity values for the different layers are very similar, consistent with the layers that have similar composition.

The input data are averaged for the layer under investigation. The only exception to this is the heat capacity values of the Calico Hills Formation and adjacent layers of bedded tuffs that are separated into vitric and zeolitic regions. In general, the developed values of heat capacity are appropriate because the layers are compositionally and mechanically homogeneous. However, users of these data need to be aware of the limitation in the following cases:

1. When a location-specific estimate of heat capacity for a time-dependent problem is required, or

2. When spatial variability within a layer is required.

The values for rock-mass heat capacity are only valid to two significant figures, and are presented in scientific notation to prevent use of the values beyond the intended precision. The standard deviation assigned to each model layer is approximately 30 percent of the average value. Thirty percent of the mean was selected as the uncertainty associated with the rock-mass heat capacity values; the selection was based on the standard deviations calculated for the rock-grain heat capacities.

\subsection{YUCCA MOUNTAIN REVIEW PLAN CRITERIA ASSESSMENT}

This section provides responses to the Yucca Mountain Review Plan acceptance criteria applicable to this model report. The acceptance criteria for the quantity and chemistry of water that comes into contact with engineered barriers and waste forms are referenced from Section 2.2.1.3.3.3 of NRC (2003 [DIRS 163274]) and 10 CFR 63.114(a)-(c) and (e)-(g) [DIRS 156605]. 


\subsubsection{Acceptance Criterion 1 - System Description and Model Integration Are Adequate}

(2) The abstraction of the quantity and chemistry of water contacting engineered barriers and waste forms uses assumptions, technical bases, data, and models, that are appropriate and consistent with other related U.S. Department of Energy abstractions. For example, the assumptions used for the quantity and chemistry of water contacting engineered barriers and waste forms are consistent with the abstractions of "Degradation of Engineered Barriers" (Section 2.2.1.3.1); "Mechanical Disruption of Waste Packages" (Section 2.2.1.3.2); "Radionuclide Release Rates and Solubility Limits" (Section 2.2.1.3.4); "Climate and Infiltration" (Section 2.2.1.3.5); and "Flow Paths in the Unsaturated Zone" (Section 2.2.1.3.6). The descriptions and technical bases provide transparent and traceable support for the abstraction of quantity and chemistry of water contacting engineered barriers and waste forms.

The data (Section 4.1), assumptions (Section 5), and technical bases (Section 6) used to develop heat capacity values are appropriate and consistent with the use of these values and their uncertainties as inputs to the mountain and drift-scale coupled process models. The descriptions and technical bases presented in Section 6 provide transparent and traceable support for the heat capacity parameter development. The use of heat capacity parameter values and their uncertainties by downstream coupled processes models that support the TSPA-LA is documented in the reports associated with those models.

\subsubsection{Acceptance Criterion 2 - Data Are Sufficient for Model Justification}

(1) Geological, hydrological, and geochemical values used in the license application are adequately justified. Adequate description of how the data were used, interpreted, and appropriately synthesized into the parameters is provided.

Site-specific mineral abundance values as well as data for rock matrix properties obtained from core sample measurements are inputs to the heat capacity analysis. The input data and their appropriateness in analyses selection and development are described in Section 4.1 and Section 6. Descriptions of how the data are used, interpreted, and synthesized into the developed parameters (i.e., rock-grain heat capacity and rock-mass heat capacity) are included in Section 6, and in Appendix A and Appendix B.

(2) Sufficient data were collected on the characteristics of the natural system and engineered materials to establish initial and boundary conditions for conceptual models of thermal-hydrologic-mechanical-chemical coupled processes that affect seepage and flow and the waste package chemical environment.

Data were collected from lithostratigraphic layers at Yucca Mountain, as described in Section 4.1 and Section 6, to support the rock-grain and rock-mass heat capacity analyses. The results of these analyses, summarized in Section 6 and output DTN: SN0307T0510902.003, are used to develop and execute models of coupled processes that affect seepage and flow and the waste package environment. 


\subsubsection{Acceptance Criterion 3 - Data Uncertainty Is Characterized and Propagated Through the Model Abstraction}

(1) Models use parameter values, assumed ranges, probability distributions, and bounding assumptions that are technically defensible, reasonably account for uncertainties and variabilities, and do not result in an under-representation of the risk estimate.

The input data described in Section 4.1 and used in the analyses described in Section 6 are representative of the various lithostratigraphic layers at Yucca Mountain. The data originate from qualified and controlled sources. Measurement errors, biases, and natural sample variabilities are propagated into the heat capacity analyses (Section 6.6). For example, these analyses account for the variability of the mineral abundance data (Section 6.3). This variability is used to estimate the standard deviation, a measure of variability and uncertainty, of the rock-grain heat capacity for each lithostratigraphic unit (Section 6.6). Similarly, the rock-grain heat capacity values are also used to estimate the mean and the standard deviation of the rock-mass heat capacity in each lithostratigraphic unit (Section 6.7). Again, the standard deviation values provide a measure of the variability and uncertainty of the rock-mass heat capacity in each lithostratigraphic unit. Therefore, the analytical approach used to develop the heat capacity parameters accounts for uncertainties and variabilities, and does not result in an under-representation of risk.

(2) Parameter values, assumed ranges, probability distributions, and bounding assumptions used in the total system performance assessment calculations of quantity and chemistry of water contacting engineered barriers and waste forms are technically defensible and reasonable, based on data from the Yucca Mountain region (e.g., results from large block and drift-scale heater and niche tests), and a combination of techniques that may include laboratory experiments, field measurements, natural analog research, and process-level modeling studies.

The heat capacity parameter values, developed in this report, are used in coupled process modeling that supports TSPA-LA calculations of quantity and chemistry of water that comes into contact with engineered barriers and waste forms. These parameter values are based on mineralogic data (Section 6.3) and rock matrix property data (Section 6.7) that are specific to Yucca Mountain.

(3) Input values used in the total system performance assessment calculations of quantity and chemistry of water contacting engineered barriers (e.g., drip shield and waste package) are consistent with the initial and boundary conditions and the assumptions of the conceptual models and design concepts for the Yucca Mountain site. Correlations between input values are appropriately established in the U.S. Department of Energy total system performance assessment. Parameters used to define initial conditions, boundary conditions, and computational domain in sensitivity analyses involving coupled thermal-hydrologic-mechanicalchemical effects on seepage and flow, the waste package chemical environment, and the chemical environment for radionuclide release, are consistent with 
available data. Reasonable or conservative ranges of parameters or functional relations are established.

The heat capacity parameters developed in this report are inputs to calculations that directly support the TSPA-LA with regard to the quantity and chemistry of water that comes into contact with engineered barriers and waste forms. The heat capacity analyses are consistent with the available site-specific data (Section 6.3 and Section 6.7). The standard deviation of the rock-mass heat capacity described in Section 6.7 provides a reasonable range for establishing the range of values for use in TSPA-LA sensitivity calculations.

(4) Adequate representation of uncertainties in the characteristics of the natural system and engineered materials is provided in parameter development for conceptual models, process-level models, and alternative conceptual models. The U.S. Department of Energy may constrain these uncertainties using sensitivity analyses or conservative limits. For example, the U.S. Department of Energy demonstrates how parameters used to describe flow through the engineered barrier system bound the effects of excavation-induced changes.

The analyses documented in this report provide estimates of the standard deviation in rock-grain heat capacity (Section 6.6) and in rock-mass heat capacity (Section 6.7) in all lithostratigraphic units at Yucca Mountain. These standard deviations are a reflection of the uncertainty caused by measurement errors, biases, and natural sample variabilities propagated through each analysis (Section 6.6). The use of heat capacity parameter values and their uncertainties by down-stream process models that support the TSPA-LA is documented in the associated model reports.

\subsubsection{Acceptance Criterion 4 - Model Uncertainty Is Characterized and Propagated Through the Model Abstraction}

(2) Alternative modeling approaches are considered and the selected modeling approach is consistent with available data and current scientific understanding. A description that includes a discussion of alternative modeling approaches not considered in the final analysis and the limitations and uncertainties of the chosen model is provided.

Alternative conceptual approaches for estimating the rock-grain heat capacity are discussed in Section 6.1. The rationale used in the analysis selection process is consistent both with the nature of the available input data and with the use of the resulting heat capacity values. The limitations of the heat capacity analyses are discussed in Section 6.1; the uncertainties are provided in Section 6.6 and Section 6.7. 


\section{INPUTS AND REFERENCES}

The following is a list of the references cited in this document. Column 2 represents the unique six-digit numerical identifier (the Document Input Reference System [DIRS] number), which is placed in the text following the reference callout (e.g., BSC 2004 [DIRS 169900]). The purpose of these numbers is to assist the reader in locating a specific reference. Within the reference list, multiple sources by the same author (e.g., BSC 2004) are sorted alphabetically by title.

\subsection{DOCUMENTS CITED}

Berman, R.G. and Brown, T.H. 1985. "Heat Capacity of Minerals in the System

104907 $\mathrm{Na} 2 \mathrm{O}-\mathrm{K} 2 \mathrm{O}-\mathrm{CaO}-\mathrm{MgO}-\mathrm{FeO}-\mathrm{Fe} 2 \mathrm{O} 3-\mathrm{Al} 2 \mathrm{O} 3-\mathrm{SiO} 2-\mathrm{TiO} 2-\mathrm{H} 2 \mathrm{O}-\mathrm{CO} 2$ :

Representation, Estimation, and High Temperature Extrapolation." Contributions to Mineralogy and Petrology, 89, 168-183. New York, New York: Springer-Verlag. TIC: 235118.

Berryman, James G. 1995. "Mixture Theories for Rock Properties." $A G U$ 159696 Reference Shelf 3, Rock Physics and Phase Relations A Handbook of Physical Constants. Ahrens, T.J. Pages 205-228. Washington, D.C.: American Geophysical Union. TIC: 239165.

BSC (Bechtel SAIC Company) 2004. Analysis of Hydrologic Properties Data. 170038 ANL-NBS-HS-000042 REV 00. Las Vegas, Nevada: Bechtel SAIC Company. ACC: DOC.20041005.0004.

BSC 2004. Mineralogic Model (MM3.0) Report. MDL-NBS-GS-000003 REV 01. 170031 Las Vegas, Nevada: Bechtel SAIC Company. ACC: DOC.20040908.0006.

BSC 2004. Multiscale Thermohydrologic Model. ANL-EBS-MD-000049 REV 02. 169565 Las Vegas, Nevada: Bechtel SAIC Company. ACC: DOC.20041014.0008.

BSC 2004. Q-List. 000-30R-MGR0-00500-000-000 REV 00. Las Vegas, 168361 Nevada: Bechtel SAIC Company. ACC: ENG.20040721.0007.

BSC 2004. Technical Work Plan for: Near-Field Environment and Transport 171708 Thermal Properties Model and Analysis Reports Integration.

TWP-MGR-PA-000019 REV 00 ICN 01. Las Vegas, Nevada: Bechtel SAIC Company. ACC: DOC.20040920.0003.

BSC 2004. Thermal Testing Measurements Report. TDR-MGR-HS-000002 REV 00. Las Vegas, Nevada: Bechtel SAIC Company. ACC: DOC.20040928.0005. 
Buesch, D.C. and Spengler, R.W. 1999. "Correlations of Lithostratigraphic

107905

Features with Hydrogeologic Properties, a Facies-Based Approach to Model

Development in Volcanic Rocks at Yucca Mountain, Nevada." Proceedings of

Conference on Status of Geologic Research and Mapping in Death Valley National

Park, Las Vegas, Nevada, April 9-11, 1999. Slate, J.L., ed. Open-File Report

99-153. Pages 62-64. Denver, Colorado: U.S. Geological Survey. TIC: 245245.

Buesch, D.C.; Spengler, R.W.; Moyer, T.C.; and Geslin, J.K. 1996. Proposed

100106

Stratigraphic Nomenclature and Macroscopic Identification of Lithostratigraphic

Units of the Paintbrush Group Exposed at Yucca Mountain, Nevada. Open-File

Report 94-469. Denver, Colorado: U.S. Geological Survey.

ACC: MOL.19970205.0061.

Bulmer, M.G. 1979. Principles of Statistics. 3rd Edition. New York,

New York: Dover. TIC: 245835.

Canori, G.F. and Leitner, M.M. 2003. Project Requirements Document.

166275

TER-MGR-MD-000001 REV 02. Las Vegas, Nevada: Bechtel SAIC Company.

ACC: DOC.20031222.0006.

Chipera, S.J.; Bish, D.L.; and Carlos, B.A. 1995. "Equilibrium Modeling of the

100025

Formation of Zeolites in Fractures at Yucca Mountain, Nevada." Natural Zeolites

'93: Occurrence, Properties, Use, Proceedings of the 4th International Conference

on the Occurrence, Properties, and Utilization of Natural Zeolites, June 20-28,

1993, Boise, Idaho. Ming, D.W. and Mumpton, F.A., eds. Pages 565-577.

Brockport, New York: International Committee on Natural Zeolites.

TIC: 243086.

CRWMS (Civilian Radioactive Waste Management System) M\&O (Management

100223

and Operating Contractor) 1997. Determination of Available Volume for Repository Siting. BCA000000-01717-0200-00007 REV 00. Las Vegas,

Nevada: CRWMS M\&O. ACC: MOL.19971009.0699.

CRWMS M\&O 2000. Input Parameters for Thermal Modeling Using

Conduction-Only Models. CAL-NBS-TH-000001 REV 00. Las Vegas,

Nevada: CRWMS M\&O. ACC: MOL.20001107.0365.

Deer, W.A.; Howie, R.A.; and Zussman, J. 1966. An Introduction to the

102773

Rock-Forming Minerals. New York, New York: John Wiley \& Sons.

TIC: 245492.

Flint, L.E. 1998. Characterization of Hydrogeologic Units Using Matrix

100033

Properties, Yucca Mountain, Nevada. Water-Resources Investigations Report 97-4243. Denver, Colorado: U.S. Geological Survey.

ACC: MOL.19980429.0512. 
Johnson, G.K.; Flotow, H.E.; O'Hare, P.A.G.; and Wise, W.S. 1982.

106283

"Thermodynamic Studies of Zeolites: Analcime and Dehydrated Analcime." American Mineralogist, 67, 736-748. Washington, D.C.: Mineralogical Society of America. TIC: 238577.

Klein, C. and Hurlbut, C.S., Jr. 1999. Manual of Mineralogy. 21st Edition,

Revised. New York, New York: John Wiley \& Sons. TIC: 246258.

Lide, D.R., ed. 2002. CRC Handbook of Chemistry and Physics. 83rd Edition.

160832 Boca Raton, Florida: CRC Press. TIC: 253582.

Lum, C. 2004. "Addition to Records Package MOY-030731-07-01." E-mail from

172044

C. Lum to D. Ashley. ACC: MOL.20041020.0105.

Nimick, F.B. and Connolly, J.R. 1991. Calculation of Heat Capacities for

Tuffaceous Units from the Unsaturated Zone at Yucca Mountain, Nevada.

SAND88-3050. Albuquerque, New Mexico: Sandia National Laboratories.

ACC: NNA.19910308.0017.

NRC (U.S. Nuclear Regulatory Commission) 2003. Yucca Mountain Review Plan,

163274

Final Report. NUREG-1804, Rev. 2. Washington, D.C.: U.S. Nuclear Regulatory

Commission, Office of Nuclear Material Safety and Safeguards. TIC: 254568.

Peterman, Z.E. and Cloke, P.L. 2002. "Geochemistry of Rock Units at the Potential Repository Level, Yucca Mountain, Nevada (includes Erratum)." Applied Geochemistry, 17, (6, 7), 683-698, 955-958. New York, New York: Pergamon. TIC: $252516 ; 252517$.

Robie, R.A. and Hemingway, B.S. 1995. Thermodynamic Properties of Minerals and Related Substances at 298.15 K and 1 Bar (105 Pascals) Pressure and at Higher Temperatures. Bulletin 2131. Reston, Virginia: U.S. Geological Survey. TIC: 249441.

Robie, R.A.; Hemingway, B.S.; and Fisher, J.R. 1979. Thermodynamic Properties of Minerals and Related Substances at $298.15 \mathrm{~K}$ and 1 Bar (10 $0^{5}$ Pascals) Pressure and at Higher Temperatures. U.S. Geological Survey Bulletin 1452. Washington, D.C.: U.S. Government Printing Office. TIC: 230505.

Robinson, G.R., Jr. and Haas, J.L., Jr. 1983. "Heat Capacity, Relative Enthalpy, and Calorimetric Entropy of Silicate Minerals: An Empirical Method of Prediction." American Mineralogist, 68, 541-553.

Washington, D.C.: Mineralogical Society of America. TIC: 224442.

Thompson, A.B. and Wennemer, M. 1979. "Heat Capacities and Inversions in Tridymite, Cristobalite, and Tridymite-Cristobalite Mixed Phases." American Mineralogist, 64, 1018-1026. Washington, D.C.: Mineralogical Society of America. TIC: 239133. 


\subsection{CODES, STANDARDS, REGULATIONS, AND PROCEDURES}

10 CFR 63. Energy: Disposal of High-Level Radioactive Wastes in a Geologic 156605 Repository at Yucca Mountain, Nevada. Readily available.

AP-2.22Q, Rev. 1, ICN 1. Classification Analyses and Maintenance of the Q-List. Washington, D.C.: U.S. Department of Energy, Office of Civilian Radioactive Waste Management. ACC: DOC.20040714.0002.

AP-SIII.9Q, Rev. 1, ICN 7. Scientific Analyses. Washington, D.C.: U.S. Department of Energy, Office of Civilian Radioactive Waste Management.

ACC: DOC.20040920.0001.

LP-SI.11Q-BSC, Rev. 0, ICN 1. Software Management. Washington, D.C.: U.S. Department of Energy, Office of Civilian Radioactive Waste Management.

ACC: DOC.20041005.0008.

\subsection{SOURCE DATA, LISTED BY DATA TRACKING NUMBER}

GS000108314211.001. Stratigraphic Contacts for Boreholes USW G-3/GU-3, USW G-4, USW NRG-6, USW NRG-7/7A, USW SD-6/SD-6ST1, USW UZ-14, UE-25 WT\#14, and USW WT-24. Submittal date: 01/31/2000.

GS000308313211.001. Geochemistry of Repository Block. Submittal 162015 date: $03 / 27 / 2000$.

GS000308314211.002. Stratigraphic Contacts for Boreholes UE-25 A\#1, UE-25 A\#4, USW G-1, USW G-2, USW H-5, USW SD-9, USW SD-12 and USW VH-2. Submittal date: 04/28/2000.

GS000608314211.003. Stratigraphic Contact for 26 Yucca Mountain Boreholes. Submittal date: 04/09/2001.

GS980708312242.010. Physical Properties of Borehole Core Samples, and Water 106752 Potential Measurements Using the Filter Paper Technique, for Borehole Samples from USW WT-24. Submittal date: 07/27/1998.

GS980808312242.014. Physical Properties of Borehole Core Samples and Water Potential Measurements Using the Filter Paper Technique for Borehole Samples from USW SD-6. Submittal date: 08/11/1998.

LA9908JC831321.001. Mineralogic Model "MM3.0" Version 3.0. Submittal date: $08 / 16 / 1999$.

MO0004QGFMPICK.000. Lithostratigraphic Contacts from MO9811MWDGFM03.000 to be Qualified Under the Data Qualification Plan, TDP-NBS-GS-000001. Submittal date: 04/04/2000. 
MO0009THRMODYN.001. Input Transmittal for Thermodynamic Data Input

152576

Files for Geochemical Calculations. Submittal date: 09/20/2000.

MO0012MWDGFM02.002. Geologic Framework Model (GFM2000). Submittal

153777 date: $12 / 18 / 2000$.

MO0109HYMXPROP.001. Matrix Hydrologic Properties Data. Submittal date: $09 / 17 / 2001$.

MO0302SPATHDYN.001. Thermodynamic Data Supporting Spreadsheet Files - Data0.YMP.R2. Submittal date: 02/05/2003.

161886

MO9510RIB00002.004. RIB Item: Stratigraphic Characteristics: Geologic/

103801

Lithologic Stratigraphy. Submittal date: 06/26/1996.

MO9901MWDGFM31.000. Geologic Framework Model. Submittal

103769 date: $01 / 06 / 1999$.

SN0210T0510902.001. Heat Capacity of Yucca Mountain Stratigraphic Units.

161244

Submittal date: 10/25/2002.

SN0303T0510902.002. Revised Heat Capacity of Yucca Mountain Stratigraphic

162496

Units. Submittal date: 03/28/2003.

SN0402T0503102.010. Heat Capacity Values for Lithostratigraphic Layers of

Yucca Mountain. Submittal date: 02/24/2004.

SNF40060298001.001. Unsaturated Zone Lithostratigraphic Contacts in Borehole USW SD-6. Submittal date: 10/15/1998.

\subsection{OUTPUT DATA, LISTED BY DATA TRACKING NUMBER}

SN0307T0510902.003. Updated Heat Capacity of Yucca Mountain Stratigraphic Units. Submittal date: 07/15/2003.

SN0409T0510902.004. Supporting Files For Heat Capacity Analysis Report. Submittal date: 09/02/2004.

\subsection{SOFTWARE CODES}

Dynamic Graphics 2000. Software Code: EARTHVISION. V5.1. SGI/IRIX 6.5. 167994 10174-5.1-00. 
INTENTIONALLY LEFT BLANK 
APPENDIX A

HEAT CAPACITY OF THE TEN MINERAL GROUPS 
A listing of heat capacity data for the ten mineral groups is given below. The data have been compiled from the sources listed in Table 4-2. This appendix contains the heat capacity equation, data source, and molecular weight for each mineral. The applicable temperature range for each mineral's heat capacity equation is given if it was provided in the data source. For this study, the original units of heat capacity have been converted to $\mathrm{J} / \mathrm{g}-\mathrm{K}$. Output DTN: SN0409T0510902.004 contains the Excel spreadsheets used in the development of the mineral group heat capacity results presented in this appendix. In all equations given in Appendix A, the temperature is in kelvins. The average heat capacity, over a temperature range of $25^{\circ} \mathrm{C}$ to $325^{\circ} \mathrm{C}$, is given for each mineral or mineral group. For minerals clinoptilolite, mordenite, chabazite, erionite, stellerite, and analcime, the molecular weights were determined using the element atomic weights provided in the CRC Handbook of Chemistry and Physics (Lide 2002 [DIRS 160832], pp. 1-12 and 1-13).

\section{A1. SMECTITE AND ILLITE}

\section{A1.1 SMECTITE}

Smectite-high-Fe-Mg

Formula: $\mathrm{Ca}_{0.025} \mathrm{Na}_{0.1} \mathrm{~K}_{0.2} \mathrm{Fe}++{ }_{0.5} \mathrm{Fe}+++{ }_{0.2} \mathrm{Mg}_{1.15} \mathrm{Al}_{1.25} \mathrm{Si}_{3.5} \mathrm{H}_{2} \mathrm{O}_{12}$

Molecular weight (mol. wt.) $=404.198 \mathrm{~g} / \mathrm{mol}$

$\mathrm{C}_{\mathrm{p}}=\mathrm{a}+\mathrm{bT}+\mathrm{cT}^{-2}[\mathrm{~J} / \mathrm{g}-\mathrm{K}]$

$\mathrm{a}=8.97318 \times 10^{-1}$

$\mathrm{b}=4.14986 \times 10^{-4}$

$\mathrm{c}=-1.60343 \times 10^{4}$

Temperature limit $=326.85^{\circ} \mathrm{C}$

Average $\mathrm{C}_{\mathrm{p}}=0.99[\mathrm{~J} / \mathrm{g}-\mathrm{K}]$

NOTE: The specific heat for Smectite-low-Fe-Mg $\left(\mathrm{Ca}_{0.02} \mathrm{Na}_{0.15} \mathrm{~K}_{0.29} \mathrm{Fe}+{ }_{0.5} \mathrm{Fe}+++{ }_{0.16} \mathrm{Mg}_{0.9} \mathrm{Al}_{1.25} \mathrm{Si}_{3.7} \mathrm{H}_{2} \mathrm{O}\right)$ is nearly identical.

Source: DTN: MO0009THRMODYN.001 [DIRS 152576].

\section{A1.2 ILLITE}

Formula: $\mathrm{K}_{0.6} \mathrm{Mg}_{0.25} \mathrm{Al}_{2.3} \mathrm{Si}_{3.5} \mathrm{O}_{10}(\mathrm{OH})_{2}$

mol. wt. $=383.901 \mathrm{~g} / \mathrm{mol}$

$\mathrm{C}_{\mathrm{p}}=\mathrm{a}+\mathrm{bT}+\mathrm{cT}^{-2}[\mathrm{~J} / \mathrm{g}-\mathrm{K}]$

$\mathrm{a}=9.37763 \times 10^{-1}$

$\mathrm{b}=4.20361 \times 10^{-4}$

$\mathrm{c}=-1.94214 \times 10^{4}$ 
Temperature limit $=326.85^{\circ} \mathrm{C}$

Average $\mathrm{C}_{\mathrm{p}}=1.02[\mathrm{~J} / \mathrm{g}-\mathrm{K}]$

Source: DTN: MO0009THRMODYN.001 [DIRS 152576].

\section{A1.3 GROUP HEAT CAPACITY (SMECTITE + ILLITE)}

The heat capacities of smectite and illite are virtually the same (Figure A-1). Above the water table, the smectites typically have nonexpandable illite contents of 10 to 20 percent. Well below the water table (depths greater than 1000 meters or 3,300 feet below the surface), the ancient geothermal system generated abundant smectite + illite, but with a much higher illite content ( 80 to 90 percent) (BSC 2004 [DIRS 170031], Section 6.3.3). The primary area of interest is above the water table. In addition, below the water table, the heat capacity behavior will be controlled by the fluid phase, not the solid matrix material. Therefore, the heat capacity of the smectite-illite mineral group will be represented by smectite, due to their similar heat capacity values and because smectite is the dominant mineral above the water table.

\section{A2. SORPTIVE ZEOLITES}

\section{A2.1 CLINOPTILOLITE}

Formula: $\mathrm{Na}_{0.954} \mathrm{~K}_{0.543} \mathrm{Ca}_{0.761} \mathrm{Mg}_{0.124} \mathrm{Sr}_{0.036} \mathrm{Ba}_{0.062} \mathrm{Mn}_{0.002} \mathrm{Al}_{3.45} \mathrm{Fe}_{0.017} \mathrm{Si}_{14.533} \mathrm{O}_{29.066} \cdot 17.856 \mathrm{H}_{2} \mathrm{O}$

mol. wt. $=1363.398 \mathrm{~g} / \mathrm{mol}$

$\mathrm{C}_{\mathrm{p}}=\mathrm{a}+\mathrm{bT}+\mathrm{cT}^{2}[\mathrm{~J} / \mathrm{g}-\mathrm{K}]$

$\mathrm{a}=3.67868 \times 10^{-2}$

$\mathrm{b}=4.66812 \times 10^{-3}$

$\mathrm{c}=-3.38537 \times 10^{-6}$

Temperature limit $=226.85^{\circ} \mathrm{C}$

Average $\mathrm{C}_{\mathrm{p}}=1.35[\mathrm{~J} / \mathrm{g}-\mathrm{K}]$

Source: DTN: MO0302SPATHDYN.001 [DIRS 161886].

\section{A2.2 MORDENITE}

Formula: $\mathrm{Ca}_{0.2895} \mathrm{Na}_{0.361} \mathrm{Al}_{0.94} \mathrm{Si}_{5.06} \mathrm{O}_{12} \cdot 3.468 \mathrm{H}_{2} \mathrm{O}$

mol. wt. $=441.847 \mathrm{~g} / \mathrm{mol}$

$\mathrm{C}_{\mathrm{p}}=\mathrm{a}+\mathrm{bT}+\mathrm{cT}^{-2}[\mathrm{~J} / \mathrm{g}-\mathrm{K}]$

$\mathrm{a}=1.19519$

$\mathrm{b}=3.67752 \times 10^{-4}$

$\mathrm{c}=-1.85507 \times 10^{4}$ 
Temperature limit $=226.85^{\circ} \mathrm{C}$

Average $\mathrm{C}_{\mathrm{p}}=1.22[\mathrm{~J} / \mathrm{g}-\mathrm{K}]$

Source: DTN: MO0302SPATHDYN.001 [DIRS 161886].

\section{A2.3 CHABAZITE}

Formula: $\mathrm{K}_{0.6} \mathrm{Na}_{0.2} \mathrm{Ca}_{1.5} \mathrm{Al}_{3.8} \mathrm{Si}_{8.2} \mathrm{O}_{24} \cdot 10.0 \mathrm{H}_{2} \mathrm{O}$

mol. wt. $=985.143 \mathrm{~g} / \mathrm{mol}$

$\mathrm{C}_{\mathrm{p}}=\mathrm{a}+\mathrm{bT} \mathrm{T}^{-0.5}+\mathrm{cT}^{-2}+\mathrm{dT}^{-3}[\mathrm{~J} / \mathrm{g}-\mathrm{K}]$

$\mathrm{a}=2.0533$

$\mathrm{b}=-1.40589 \times 10^{1}$

$\mathrm{c}=-3.06129 \times 10^{4}$

$\mathrm{d}=4.25785 \times 10^{6}$

Average $\mathrm{C}_{\mathrm{p}}=1.27[\mathrm{~J} / \mathrm{g}-\mathrm{K}]$

Source: Chipera et al. (1995 [DIRS 100025]).

\section{A2.4 ERIONITE}

Formula: $\mathrm{K}_{1.5} \mathrm{Na}_{0.9} \mathrm{Ca}_{0.9} \mathrm{Al}_{4.2} \mathrm{Si}_{13.8} \mathrm{O}_{36} \cdot 13.0 \mathrm{H}_{2} \mathrm{O}$

mol. wt. $=1426.488 \mathrm{~g} / \mathrm{mol}$

$\mathrm{C}_{\mathrm{p}}=\mathrm{a}+\mathrm{bT} \mathrm{T}^{-0.5}+\mathrm{cT}^{-2}+\mathrm{dT}^{-3}[\mathrm{~J} / \mathrm{g}-\mathrm{K}]$

(Eq. A-6)

$\mathrm{a}=1.99983$

$\mathrm{b}=-1.34786 \times 10^{1}$

$\mathrm{c}=-3.29780 \times 10^{4}$

$\mathrm{d}=4.71305 \times 10^{6}$

Average $\mathrm{C}_{\mathrm{p}}=1.24[\mathrm{~J} / \mathrm{g}-\mathrm{K}]$

Source: Chipera et al. (1995 [DIRS 100025]).

\section{A2.5 STELLERITE}

Formula: $\mathrm{Ca}_{2.0} \mathrm{Al}_{4.0} \mathrm{Si}_{14} \mathrm{O}_{36} \cdot 14.0 \mathrm{H}_{2} \mathrm{O}$

mol. wt. $=1409.471 \mathrm{~g} / \mathrm{mol}$

$\mathrm{C}_{\mathrm{p}}=\mathrm{a}+\mathrm{bT} \mathrm{T}^{-0.5}+\mathrm{cT}^{-2}+\mathrm{dT}^{-3}[\mathrm{~J} / \mathrm{g}-\mathrm{K}]$ 
$\mathrm{a}=2.04839$

$\mathrm{b}=-1.40670 \times 10^{1}$

$\mathrm{c}=-3.17725 \times 10^{4}$

$\mathrm{d}=4.44078 \times 10^{6}$

Average $\mathrm{C}_{\mathrm{p}}=1.26[\mathrm{~J} / \mathrm{g}-\mathrm{K}]$

Source: Chipera et al. (1995 [DIRS 100025]).

\section{A2.6 GROUP HEAT CAPACITY FOR SORPTIVE ZEOLITES}

For this work, the group heat capacity of sorptive zeolites was obtained by averaging the heat capacities of the individual members given in Sections A.2.1 to A.2.5 at specified temperatures. Heulandite is a fairly common mineral, but its XRD abundance was combined with clinoptilolite because the two minerals have the same crystal structure (BSC 2004 [DIRS 170031], p. 6-21). Because no XRD abundance of heulandite is available, its heat capacity was not included in the zeolite mineral group average. Due to the similar structure and chemical composition with clinoptilolite, not including heulandite in the average will have only a minor impact on the average zeolite-mineral-group heat capacity value. Figure A-2 illustrates the heat capacity functions of the sorptive zeolites considered in this analysis.

Average $\mathrm{C}_{\mathrm{p}}=1.28[\mathrm{~J} / \mathrm{g}-\mathrm{K}]$

\section{A3. TRIDYMITE}

Formula: $\mathrm{SiO}_{2}$

mol. wt. $=60.085 \mathrm{~g} / \mathrm{mol}$

$\mathrm{C}_{\mathrm{p}}=\mathrm{a}+\mathrm{bT}+\mathrm{cT} \mathrm{T}^{-0.5}+\mathrm{dT}^{-2}[\mathrm{~J} / \mathrm{g}-\mathrm{K}]$

$\mathrm{a}=1.24663$

$\mathrm{b}=5.15919 \times 10^{-5}$

$\mathrm{c}=-3.93925$

$\mathrm{d}=-1.95390 \times 10^{4}$

Temperature limit $=117^{\circ} \mathrm{C}$ to $1527^{\circ} \mathrm{C}$

Robie et al. (1979 [DIRS 107109], p. 218) reported Equation A-8 to be used within the given temperature limit. They also reported a heat capacity value of $0.74228 \mathrm{~J} / \mathrm{g}-\mathrm{K}$ at $25^{\circ} \mathrm{C}$. To determine the average heat capacity for this study, a straight-line interpolation for temperatures between $25^{\circ} \mathrm{C}$ and $120^{\circ} \mathrm{C}$, and Robie et al.'s equation for temperatures between $120^{\circ} \mathrm{C}$ and $325^{\circ} \mathrm{C}$, were used (Figure A-3).

Average $\mathrm{C}_{\mathrm{p}}=0.96[\mathrm{~J} / \mathrm{g}-\mathrm{K}]$

Source: Robie et al. (1979 [DIRS 107109], p. 218). 


\section{A4. CRISTOBALITE AND OPAL-CT}

\section{A4.1 CRISTOBALITE}

Cristobalite (alpha)

Formula: $\mathrm{SiO}_{2}$

mol. wt. $=60.084 \mathrm{~g} / \mathrm{mol}$

$\mathrm{C}_{\mathrm{p}}=\mathrm{a}+\mathrm{bT}+\mathrm{cT}^{-2}[\mathrm{~J} / \mathrm{g}-\mathrm{K}]$

$\mathrm{a}=9.73509 \times 10^{-1}$

$\mathrm{b}=2.32584 \times 10^{-4}$

$\mathrm{c}=-2.65313 \times 10^{4}$

Temperature limit $=726.85^{\circ} \mathrm{C}$

Average $\mathrm{C}_{\mathrm{p}}=0.93[\mathrm{~J} / \mathrm{g}-\mathrm{K}]$

Source: DTN: MO0009THRMODYN.001 [DIRS 152576].

\section{A4.2 OPAL-CT}

Heat capacity data of opal-CT is not available.

\section{A4.3 GROUP HEAT CAPACITY (CRISTOBALITE + OPAL-CT)}

In terms of composition, opal-CT is similar to quartz and tridymite. Opal-CT has a composition of $\left(\mathrm{SiO}_{2} \mathrm{nH}_{2} \mathrm{O}\right)$, typically with a water content of 4 percent to 9 percent, and that may be as high as 20 percent (Klein and Hurlbut 1999 [DIRS 124293], p. 531). Structurally, Opal-CT is a hydrous cryptocrystalline form of cristobalite, and is comprised of aggregates of cristobalite (Deer et al. 1966 [DIRS 102773], p. 351). Plotting heat capacity curves of compositionally similar minerals (cristobalite and quartz) shows that they are almost identical for temperatures below $250^{\circ} \mathrm{C}$, with slight differences for temperatures between $250^{\circ} \mathrm{C}$ and $300^{\circ} \mathrm{C}$ (Figure A-4). The heat capacity of the cristobalite and opal-CT mineral group can, therefore, be represented by cristobalite.

\section{A5. QUARTZ}

Quartz $\left(\mathrm{SiO}_{2}\right)$

mol. wt. $=60.084 \mathrm{~g} / \mathrm{mol}$

$\mathrm{C}_{\mathrm{p}}=\mathrm{a}+\mathrm{bT}+\mathrm{cT}^{-2}[\mathrm{~J} / \mathrm{g}-\mathrm{K}]$

$\mathrm{a}=7.81314 \times 10^{-1}$

$\mathrm{b}=5.71014 \times 10^{-4}$

$\mathrm{c}=-1.88017 \times 10^{4}$ 
Temperature limit $=574.85^{\circ} \mathrm{C}$

Average $\mathrm{C}_{\mathrm{p}}=0.93[\mathrm{~J} / \mathrm{g}-\mathrm{K}]$

Source: DTN: MO0009THRMODYN.001 [DIRS 152576].

\section{A6. FELDSPARS}

Normative calculations based on a major element analysis (DTN: GS000308313211.001 [DIRS 162015]) performed in the Enhanced Characterization of the Repository Block (drift) on samples from the repository horizon (Tptpul, Tptpmn, Tptpll, and Tptln) indicate that the feldspars throughout the sequence would likely be alkali feldspars (Peterman and Cloke 2002 [DIRS 162576], Table 1). Because of their identical structure and similar composition (Na-K solid solution series from albite to orthoclase), the heat capacity for K-feldspar can be used to represent the heat capacity of Yucca Mountain feldspars.

K-Feldspar

Formula: $\mathrm{KAlSi}_{3} \mathrm{O}_{8}$

mol. wt. $=278.332 \mathrm{~g} / \mathrm{mol}$

$\mathrm{C}_{\mathrm{p}}=\mathrm{a}+\mathrm{bT}+\mathrm{cT}^{-2}[\mathrm{~J} / \mathrm{g}-\mathrm{K}]$

$\mathrm{a}=1.15174$

$\mathrm{b}=6.48047 \times 10^{-5}$

$\mathrm{c}=-4.50145 \times 10^{4}$

Temperature limit $=1126.85^{\circ} \mathrm{C}$

Average $\mathrm{C}_{\mathrm{p}}=0.93[\mathrm{~J} / \mathrm{g}-\mathrm{K}]$

Source: DTN: MO0009THRMODYN.001 [DIRS 152576].

\section{A7. VOLCANIC GLASS}

The heat capacity of volcanic glass was approximated by an average value based on the following glass compositions:

$\mathrm{Ca}_{3} \mathrm{Al}_{2} \mathrm{Si}_{3} \mathrm{O}_{12}, \mathrm{Mg}_{3} \mathrm{Al}_{2} \mathrm{Si}_{3} \mathrm{O}_{12},\left(\mathrm{Mg}_{1.5} \mathrm{Ca}_{1.5}\right) \mathrm{Al}_{2} \mathrm{Si}_{3} \mathrm{O}_{12}, \mathrm{CaSiO}_{3}, \mathrm{CaAl}_{2} \mathrm{SiO}_{6}, \mathrm{CaFeSi}_{2} \mathrm{O}_{6}, \mathrm{MgSiO}_{3}$, $\mathrm{CaMgSi}_{2} \mathrm{O}_{6}, \mathrm{NaAlSi}_{2} \mathrm{O}_{6}, \mathrm{KAlSi}_{3} \mathrm{O}_{8}, \mathrm{NaAlSi}_{3} \mathrm{O}_{8}, \mathrm{NaAlSiO}_{4}$

The heat capacity equations, temperature range of validity, and molecular weights of the individual glasses from Robie and Hemingway (1995 [DIRS 153683], pp. 31 to 40, 50 , and 58 to 66) are given below. 


\section{A7.1 $\quad \mathrm{Ca}_{3} \mathrm{Al}_{2} \mathrm{Si}_{3} \mathrm{O}_{12}$}

mol. wt. $=450.446 \mathrm{~g} / \mathrm{mol}$

$\mathrm{C}_{\mathrm{p}}=0.75303 \mathrm{~J} / \mathrm{g}-\mathrm{K}$ at $\mathrm{T}=25^{\circ} \mathrm{C}$

(Eq. A-12)

\section{A7.2 $\quad \mathrm{Mg}_{3} \mathrm{Al}_{2} \mathrm{Si}_{3} \mathrm{O}_{12}$}

mol. wt. $=403.127 \mathrm{~g} / \mathrm{mol}$

$\mathrm{C}_{\mathrm{p}}=\mathrm{a}+\mathrm{bT}+\mathrm{cT}^{-2}+\mathrm{dT}^{-0.5}[\mathrm{~J} / \mathrm{g}-\mathrm{K}]$

(Eq. A-13)

$\mathrm{a}=1.27454$

$\mathrm{b}=1.76594 \times 10^{-4}$

$\mathrm{c}=-1.45289 \times 10^{3}$

$\mathrm{d}=-6.05020$

Temperature limit $=25^{\circ} \mathrm{C}$ to $747^{\circ} \mathrm{C}$

\section{A7.3 $\quad\left(\mathrm{Mg}_{1.5} \mathrm{Ca}_{1.5}\right) \mathrm{Al}_{2} \mathrm{Si}_{3} \mathrm{O}_{12}$}

mol. wt. $=426.787 \mathrm{~g} / \mathrm{mol}$

$\mathrm{C}_{\mathrm{p}}=0.78 \mathrm{~J} / \mathrm{g}-\mathrm{K}$ at $\mathrm{T}=25^{\circ} \mathrm{C}$

\section{A7.4 $\mathrm{CaSiO}_{3}$}

mol. wt. $=116.162 \mathrm{~g} / \mathrm{mol}$

$\mathrm{C}_{\mathrm{p}}=\mathrm{a}+\mathrm{bT}+\mathrm{cT}^{-2}[\mathrm{~J} / \mathrm{g}-\mathrm{K}]$

(Eq. A-15)

$\mathrm{a}=0.83409$

$\mathrm{b}=2.94847 \times 10^{-4}$

$\mathrm{c}=-1.55300 \times 10^{4}$

Temperature limit $=25^{\circ} \mathrm{C}$ to $1548^{\circ} \mathrm{C}$

\section{A7.5 $\quad \mathrm{CaAl}_{2} \mathrm{SiO}_{6}$}

mol. wt. $=218.123 \mathrm{~g} / \mathrm{mol}$

$\mathrm{C}_{\mathrm{p}}=0.76 \mathrm{~J} / \mathrm{g}-\mathrm{K}$ at $\mathrm{T}=25^{\circ} \mathrm{C}$

(Eq. A-16)

\section{A7.6 $\mathrm{CaFeSi}_{2} \mathrm{O}_{6}$}

mol. wt. $=248.092 \mathrm{~g} / \mathrm{mol}$

$\mathrm{C}_{\mathrm{p}}=0.70 \mathrm{~J} / \mathrm{g}-\mathrm{K}$ at $\mathrm{T}=25^{\circ} \mathrm{C}$

(Eq. A-17) 


\section{A7.7 $\mathrm{CaMgSi}_{2} \mathrm{O}_{6}$}

mol. wt. $=216.55 \mathrm{~g} / \mathrm{mol}$

$\mathrm{C}_{\mathrm{p}}=\mathrm{a}+\mathrm{bT}+\mathrm{cT}^{-2}+\mathrm{dT}^{-0.5}+\mathrm{eT}^{2}[\mathrm{~J} / \mathrm{g}-\mathrm{K}]$

$\mathrm{a}=4.80720$

$\mathrm{b}=-2.93604 \times 10^{-3}$

$\mathrm{c}=3.08335 \times 10^{4}$

$\mathrm{d}=-6.23874 \times 10^{1}$

$\mathrm{e}=1.25791 \times 10^{-6}$

Temperature limit $=25^{\circ} \mathrm{C}$ to $1127^{\circ} \mathrm{C}$

A7.8 $\quad \mathrm{MgSiO}_{3}$

mol. wt. $=100.389 \mathrm{~g} / \mathrm{mol}$

$\mathrm{C}_{\mathrm{p}}=0.82 \mathrm{~J} / \mathrm{g}-\mathrm{K}$ at $\mathrm{T}=25^{\circ} \mathrm{C}$

(Eq. A-19)

\section{A7.9 $\mathrm{NaAlSi}_{2} \mathrm{O}_{6}$}

mol. wt. $=202.139 \mathrm{~g} / \mathrm{mol}$

$\mathrm{C}_{\mathrm{p}}=0.82 \mathrm{~J} / \mathrm{g}-\mathrm{K}$ at $\mathrm{T}=25^{\circ} \mathrm{C}$

(Eq. A-20)

\section{A7.10 $\mathrm{KAISi}_{3} \mathrm{O}_{8}$}

mol. wt. $=278.332 \mathrm{~g} / \mathrm{mol}$

$\mathrm{C}_{\mathrm{p}}=\mathrm{a}+\mathrm{bT}+\mathrm{cT}^{-2+} \mathrm{dT}^{-0.5}+\mathrm{eT}^{2}[\mathrm{~J} / \mathrm{g}-\mathrm{K}]$

(Eq. A-21)

$\mathrm{a}=2.26169$

$\mathrm{b}=-3.89463 \times 10^{-4}$

$\mathrm{c}=8.96771 \times 10^{3}$

$\mathrm{d}=-2.59043 \times 10^{1}$

$\mathrm{e}=-6.92698 \times 10^{-8}$

Temperature limit $=25^{\circ} \mathrm{C}$ to $1027^{\circ} \mathrm{C}$

\section{A7.11 $\mathrm{NaAlSi}_{3} \mathrm{O}_{8}$}

mol. wt. $=262.223 \mathrm{~g} / \mathrm{mol}$

$\mathrm{C}_{\mathrm{p}}=\mathrm{a}+\mathrm{bT}+\mathrm{cT}^{-2}+\mathrm{dT}^{-0.5}+\mathrm{eT}^{2}[\mathrm{~J} / \mathrm{g}-\mathrm{K}]$

(Eq. A-22)

$\mathrm{a}=3.50084$

$\mathrm{b}=-1.45830 \times 10^{-3}$

$\mathrm{c}=2.01355 \times 10^{4}$ 
$\mathrm{d}=-4.38939 \times 10^{1}$

$\mathrm{e}=5.62117 \times 10^{-7}$

Temperature limit $=25^{\circ} \mathrm{C}$ to $927^{\circ} \mathrm{C}$

\section{A7.12 $\mathrm{NaAlSiO}_{4}$}

mol. wt. $=142.054 \mathrm{~g} / \mathrm{mol}$

$\mathrm{C}_{\mathrm{p}}=\mathrm{a}+\mathrm{bT}+\mathrm{cT}^{-2}+\mathrm{dT}^{-0.5}[\mathrm{~J} / \mathrm{g}-\mathrm{K}]$

$\mathrm{a}=2.23225$

$\mathrm{b}=-3.0411 \times 10^{-4}$

$\mathrm{c}=2.930576 \times 10^{3}$

$\mathrm{d}=-2.28364 \times 10^{1}$

Temperature limit $=0^{\circ} \mathrm{C}$ to $760^{\circ} \mathrm{C}$

\section{A7.13 AVERAGE HEAT CAPACITY VALUE FOR GLASSES (FROM ROBIE AND HEMINGWAY 1995 [DIRS 153683])}

The average heat capacity value for all of the above glasses over the temperature range of $25^{\circ} \mathrm{C}$ to $325^{\circ} \mathrm{C}$ is:

Average $\mathrm{C}_{\mathrm{p}}=0.96[\mathrm{~J} / \mathrm{g}-\mathrm{K}]$

\section{A8. NONSORPTIVE ZEOLITE (ANALCIME)}

Formula: $\mathrm{Na}_{0.96} \mathrm{Al}_{0.96} \mathrm{Si}_{2.04} \mathrm{O}_{6} \cdot 1.0 \mathrm{H}_{2} \mathrm{O}$

mol. wt. $=219.279 \mathrm{~g} / \mathrm{mol}$

$\mathrm{C}_{\mathrm{p}}=\mathrm{a}+\mathrm{bT}+\mathrm{cT} \mathrm{T}^{2}+\mathrm{d} \mathrm{T}^{3}[\mathrm{~J} / \mathrm{g}-\mathrm{K}]$

$\mathrm{a}=1.08369$

$\mathrm{b}=-2.16292 \times 10^{-3}$

$\mathrm{c}=7.59608 \times 10^{-6}$

$\mathrm{d}=-5.63675 \times 10^{-9}$

Average $\mathrm{C}_{\mathrm{p}}=1.13[\mathrm{~J} / \mathrm{g}-\mathrm{K}]$

Source: Johnson et al. (1982 [DIRS 106283], p. 744, Equation 4).

\section{A9. MUSCOVITE}

The heat capacity for muscovite is available from DTN: MO0009THRMODYN.001 [DIRS 152576]. A heat capacity value for biotite is not available. Structurally, biotite and muscovite are both sheet silicates and, compositionally, they are very similar (biotite is Fe rich, 
and muscovite is Al rich (Deer et al. 1966 [DIRS 102773], pp. 201 and 211)). Because of their similar structure, the heat capacity of muscovite can be used to represent mica.

Formula: $\mathrm{KAl}_{3} \mathrm{Si}_{3} \mathrm{O}_{10}(\mathrm{OH})_{2}$ (muscovite)

mol. wt. $=398.308 \mathrm{~g} / \mathrm{mol}$

$\mathrm{C}_{\mathrm{p}}=\mathrm{a}+\mathrm{bT}+\mathrm{cT}^{-2}[\mathrm{~J} / \mathrm{g}-\mathrm{K}]$

$\mathrm{a}=1.02481$

$\mathrm{b}=2.77107 \times 10^{-4}$

$\mathrm{c}=-2.67233 \times 10^{4}$

Temperature limit $=726.85^{\circ} \mathrm{C}$

Average $\mathrm{C}_{\mathrm{p}}=1.00[\mathrm{~J} / \mathrm{g}-\mathrm{K}]$

Source: DTN: MO0009THRMODYN.001 [DIRS 152576].

\section{A10. CALCITE}

Formula: $\mathrm{CaCO}_{3}$

mol. wt. $=100.087 \mathrm{~g} / \mathrm{mol}$

$\mathrm{C}_{\mathrm{p}}=\mathrm{a}+\mathrm{bT}+\mathrm{cT}^{-2}[\mathrm{~J} / \mathrm{g}-\mathrm{K}]$

$\mathrm{a}=1.04425$

$\mathrm{b}=2.19051 \times 10^{-4}$

$\mathrm{c}=-2.59183 \times 10^{4}$

Temperature limit $=926.85^{\circ} \mathrm{C}$

Average $\mathrm{C}_{\mathrm{p}}=1.00[\mathrm{~J} / \mathrm{g}-\mathrm{K}]$

Source: DTN: MO0009THRMODYN.001 [DIRS 152576]. 


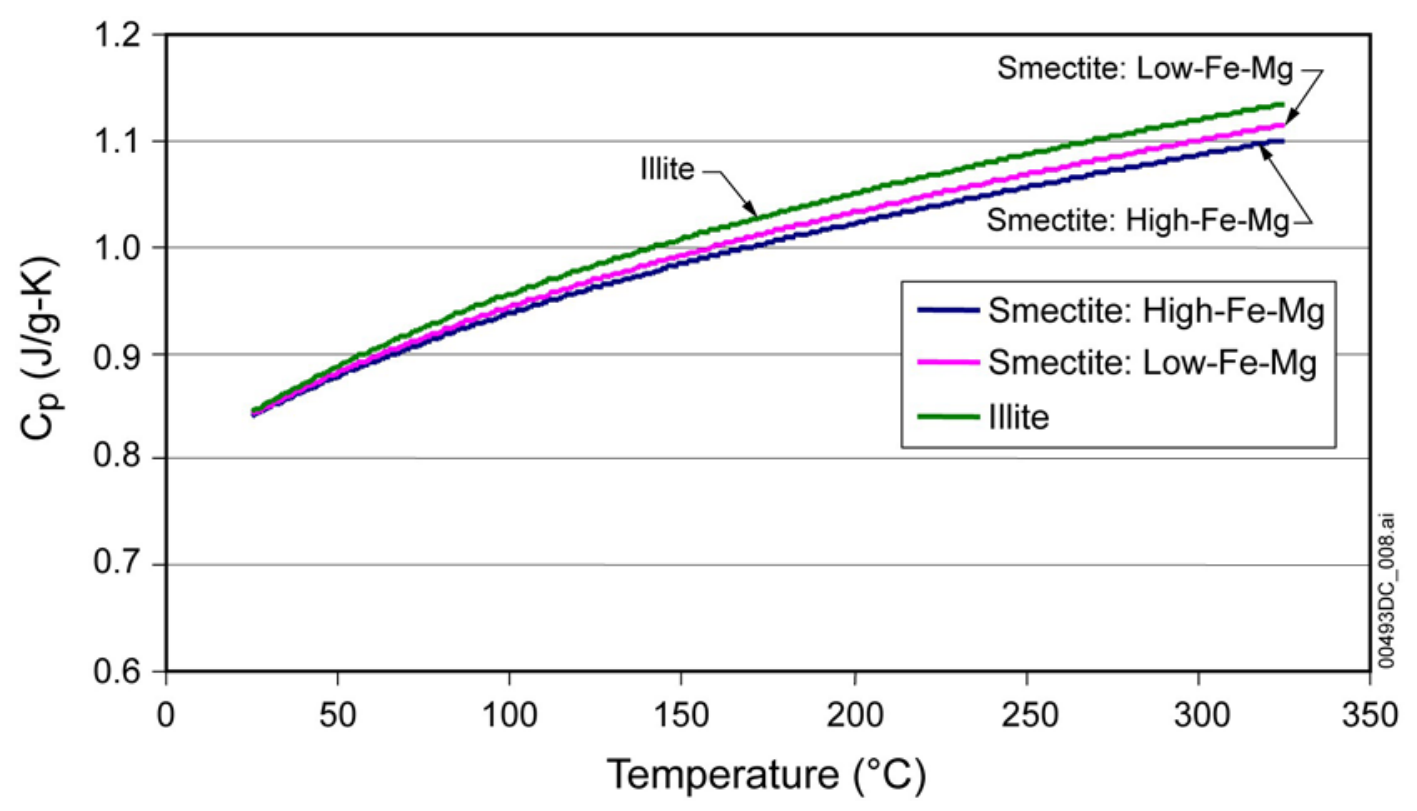

Output DTN: SN0409T0510902.004.

Figure A-1. Heat Capacity Versus Temperature: Smectite and Illite

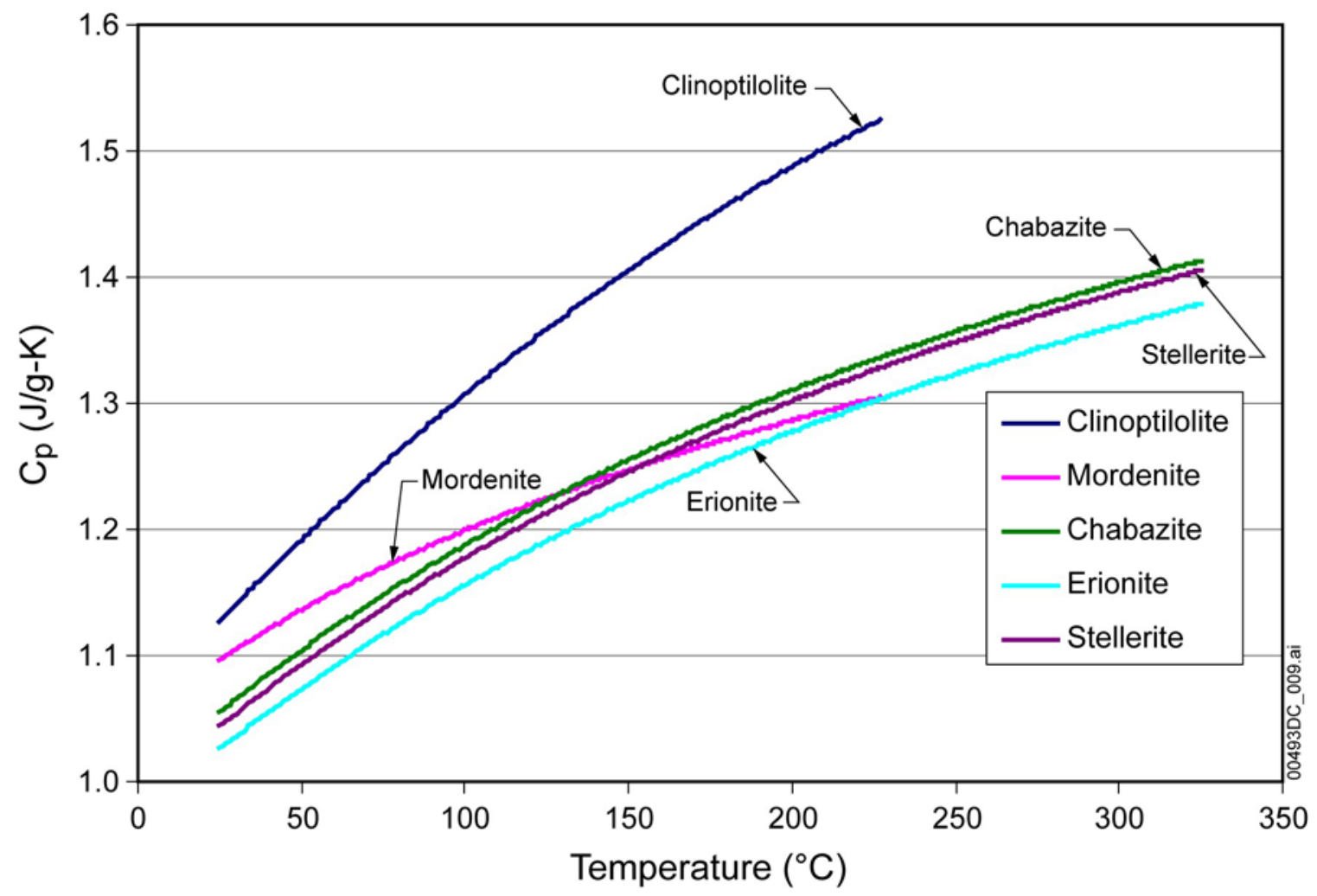

Output DTN: SN0409T0510902.004.

Figure A-2. Heat Capacity Versus Temperature: Sorptive Zeolites 


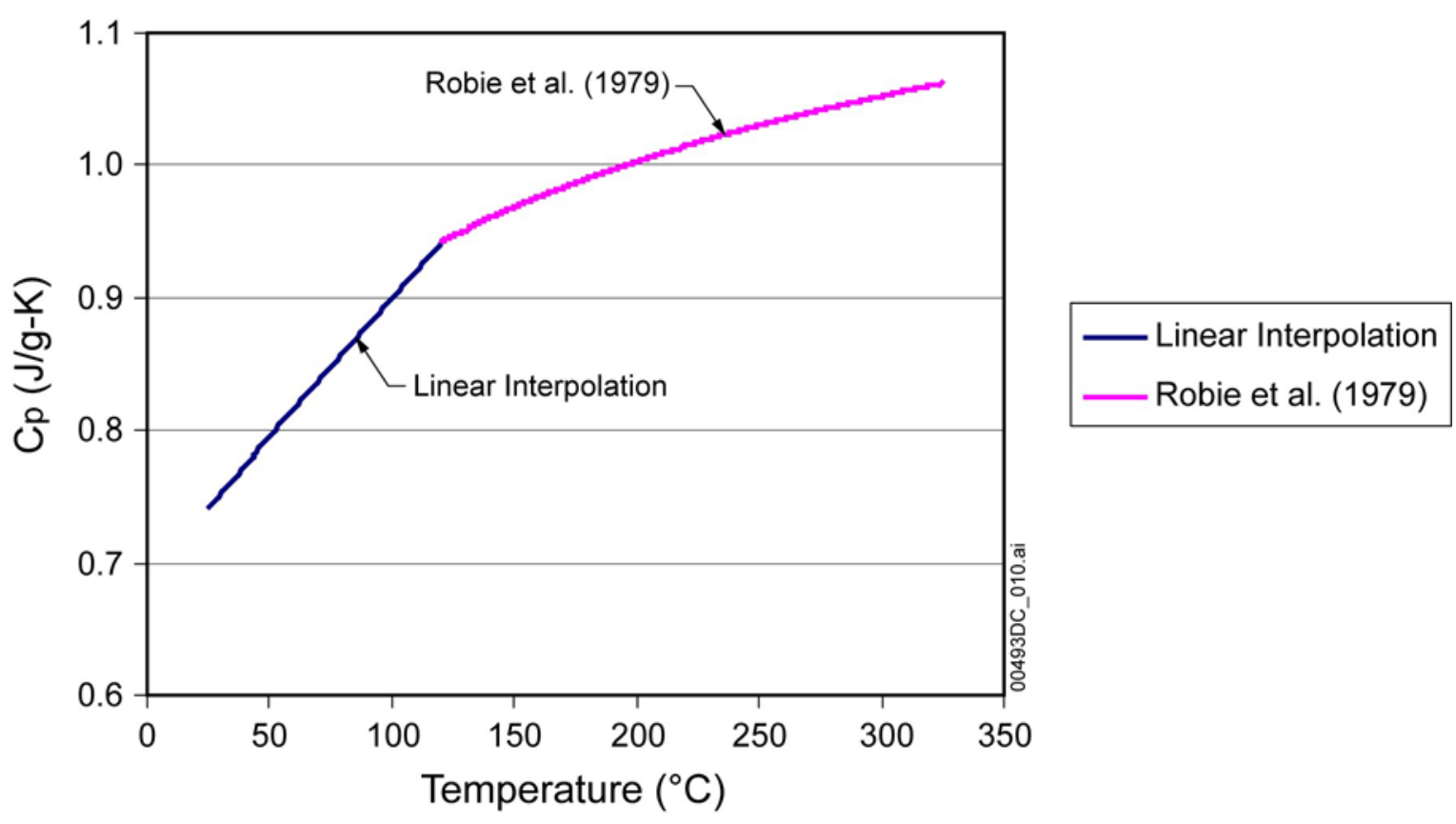

Output DTN: SN0409T0510902.004.

Figure A-3. Heat Capacity Versus Temperature: Tridymite

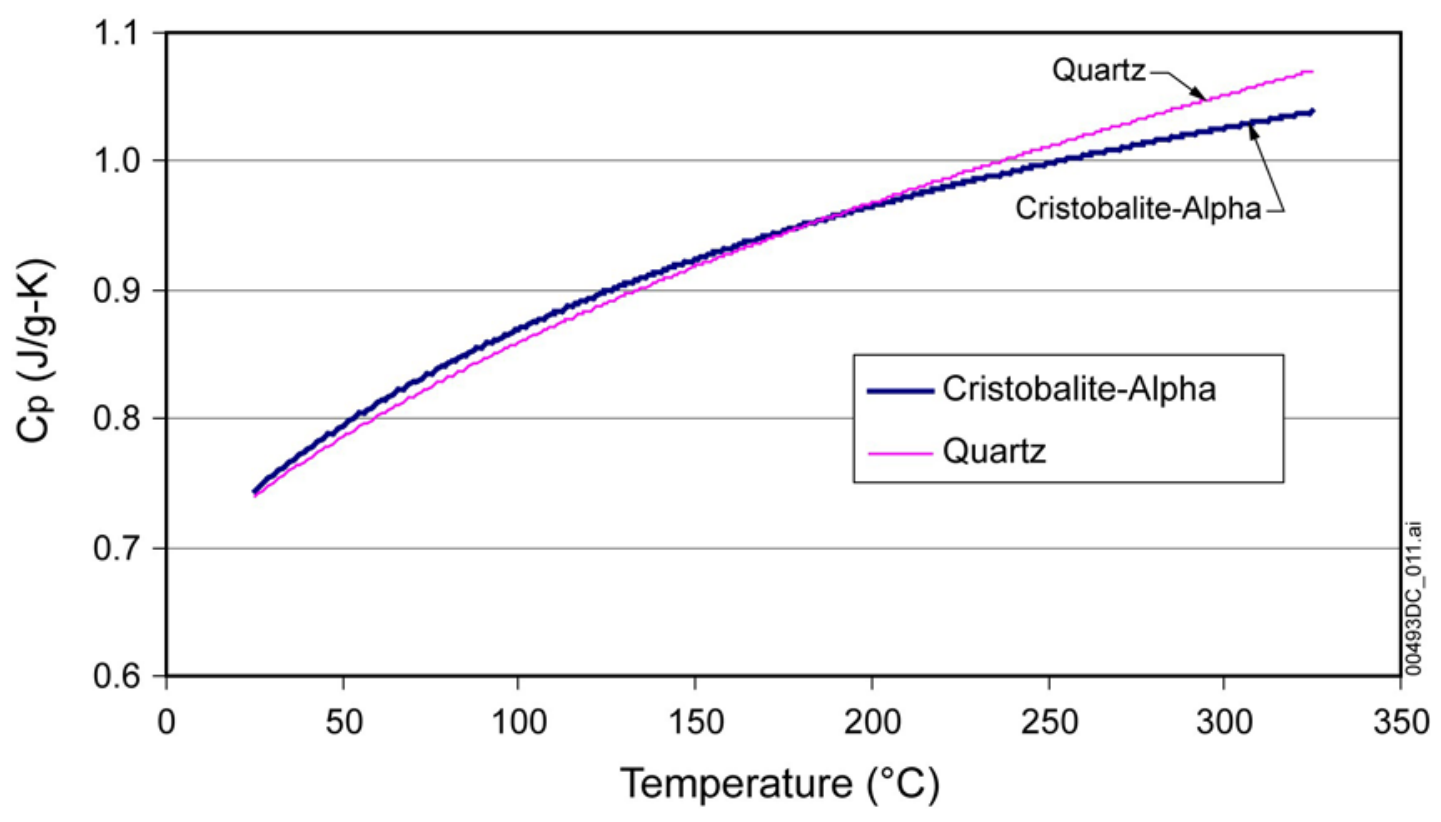

Output DTN: SN0409T0510902.004.

Figure A-4. Heat Capacity Versus Temperature: Cristobalite-Alpha and Quartz 


\section{APPENDIX B}

\section{COMPARISON OF DEVELOPED HEAT CAPACITY VALUES}


Data from four DTNs that provide rock-grain heat capacity values are shown in Table B-1:

SN0402T0503102.010 [DIRS 170993],

SN0210T0510902.001 [DIRS 161244],

SN0303T0510902.002 [DIRS 162496], and

SN0307T0510902.003 (output DTN).

DTN: SN0402T0503102.010 [DIRS 170993] was developed based on major element (oxide) data.

DTN: SN0210T0510902.001 [DIRS 161244] was developed following the mineral summation methodology outlined in this analysis report, but does not truncate the rock-grain heat capacity based on the precision of the input data.

DTN: SN0303T0510902.002 [DIRS 162496] records the preliminary data developed following the methodology documented by this report.

Output DTN: SN0307T0510902.003 is documented in the analysis and records changes required by the checking process described in AP-SIII.9Q, Scientific Analyses. These corrections and changes were minor and did not affect the product output.

For the four DTNs, the average value and associated uncertainty for two standard deviations of each layer are presented. Due to the different types of input data for the first data set, compared to the remaining DTNs, the nomenclature for the layers differs. The horizontal lines denote the equivalent formation or layer to permit comparison of heat capacity values. Comparing the major element (oxide) data and the mineral summation data in Table B-1 shows that the two methods give similar results for the average rock-grain heat capacity over the temperature range of $25^{\circ} \mathrm{C}$ to $325^{\circ} \mathrm{C}$. However, the estimates for standard deviation are, in general, higher for the mineral summation method when compared to the major-element (oxide) method suggesting a little greater spread of the obtained heat capacity values. 
Table B-1. Comparison of Oxide and Mineral Summation Methods for Rock-Grain Heat Capacity

\begin{tabular}{|c|c|c|c|c|c|c|c|c|c|c|c|}
\hline \multicolumn{3}{|c|}{$\begin{array}{c}\text { DTN: SN0402T0503102.010 } \\
\text { [DIRS 170993] } \\
\text { based on major element oxide data }\end{array}$} & \multicolumn{3}{|c|}{$\begin{array}{c}\text { DTN: SN0210T0510902.001 } \\
\text { [DIRS 161244] } \\
\text { based on mineral summation method }\end{array}$} & \multicolumn{3}{|c|}{$\begin{array}{l}\text { DTN: SN0303T0510902.002 } \\
\text { [DIRS 162496] } \\
\text { based on the method of this report }\end{array}$} & \multicolumn{3}{|c|}{\begin{tabular}{|c|} 
DTN: SN0307T0510902.003 \\
(output DTN) \\
incorporates corrections and changes \\
required by the checking process \\
per AP-SIII.9Q
\end{tabular}} \\
\hline 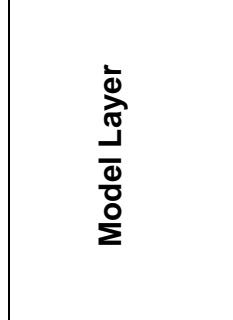 & 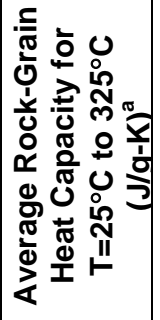 & 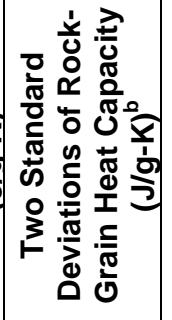 & 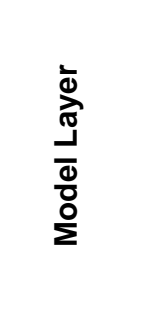 & 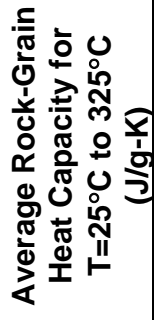 & 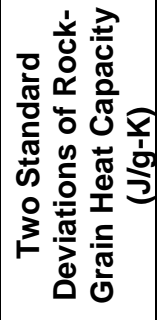 & 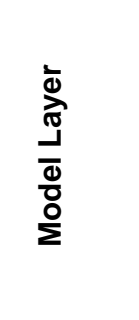 & 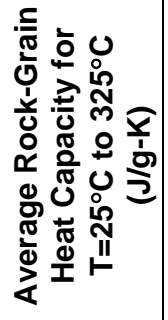 & 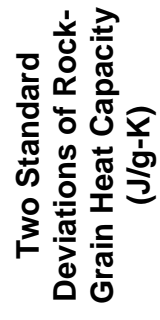 & 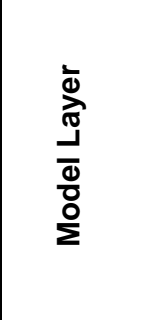 & 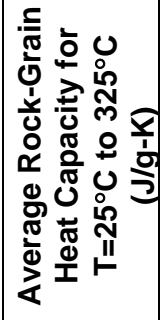 & 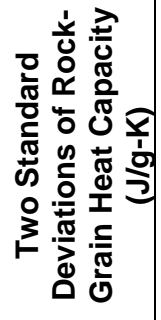 \\
\hline $\begin{array}{l}\text { Crystal Rich } \\
\text { Tiva/Post-Tiva }\end{array}$ & 0.985 & 0.202 & Tpc_un & 0.934 & 0.2 & Tpc_un & 0.93 & 0.32 & Tpc_un & 0.93 & 0.22 \\
\hline Tрср & 0.985 & 0.202 & & & & & & & & & \\
\hline TpcLD & 0.985 & 0.202 & & & & & & & & & \\
\hline Tpcpv3 & 1.040 & 0.254 & Tpcpv23 & 0.958 & 0.4 & $\begin{array}{l}\text { Tpcpv3- } \\
\text { Tpcpv2 }\end{array}$ & 0.95 & 0.28 & $\begin{array}{l}\text { Tpcpv3- } \\
\text { Tpcpv2 }\end{array}$ & 0.95 & 0.22 \\
\hline Tpcpv2 & 1.040 & 0.254 & & & & & & & & & \\
\hline Tpcpv1 & 1.040 & 0.254 & & & & & & & & & \\
\hline Tpbt4 & 1.040 & 0.254 & PTn & 0.966 & 0.4 & PTn & 0.96 & 0.58 & PTn & 0.96 & 0.46 \\
\hline Yucca & 1.040 & 0.254 & & & & & & & & & \\
\hline Tpbt3_dc & 1.040 & 0.254 & & & & & & & & & \\
\hline Pah & 1.040 & 0.254 & & & & & & & & & \\
\hline Tpbt2 & 1.040 & 0.254 & & & & & & & & & \\
\hline Tptrv3 & 1.040 & 0.254 & & & & & & & & & \\
\hline Tptrv2 & 1.040 & 0.254 & & & & & & & & & \\
\hline Tptrv1 & 1.040 & 0.254 & Tptrv1 & 0.961 & 0.4 & Tptrv1 & 0.95 & 0.28 & Tptrv1 & 0.95 & 0.20 \\
\hline Tptrn & 0.985 & 0.202 & Tptrnf & 0.937 & 0.2 & Tptrnf & 0.93 & 0.36 & Tptrnf & 0.93 & 0.26 \\
\hline Tptrl & 0.985 & 0.202 & Tptpul & 0.934 & 0.2 & Tptpul & 0.93 & 0.32 & Tptpul & 0.93 & 0.24 \\
\hline \multirow[t]{3}{*}{ Tptf } & 0.985 & 0.202 & Tptpmn & 0.932 & 0.2 & Tptpmn & 0.93 & 0.34 & Tptpmn & 0.93 & 0.28 \\
\hline & & & Tptpll & 0.933 & 0.2 & Tptpll & 0.93 & 0.34 & Tptpll & 0.93 & 0.20 \\
\hline & & & Tptpln & 0.933 & 0.2 & Tptpln & 0.93 & 0.28 & Tptpln & 0.93 & 0.26 \\
\hline Tptpv3 & 1.040 & 0.254 & & & & Tptpv3 & 0.98 & 0.56 & Tptpv3 & 0.98 & 0.48 \\
\hline
\end{tabular}


Table B-1. Comparison of Oxide and Mineral Summation Methods for Rock-Grain Heat Capacity (Continued)

\begin{tabular}{|c|c|c|c|c|c|c|c|c|c|c|c|}
\hline \multicolumn{3}{|c|}{$\begin{array}{l}\text { DTN: SN0402T0503102.010 } \\
\text { [DIRS 170993] } \\
\text { based on major element oxide data }\end{array}$} & \multicolumn{3}{|c|}{$\begin{array}{l}\text { DTN: SN0210T0510902.001 } \\
\text { [DIRS 161244] } \\
\text { based on mineral summation method }\end{array}$} & \multicolumn{3}{|c|}{$\begin{array}{c}\text { DTN: SN0303T0510902.002 } \\
\text { [DIRS 162496] } \\
\text { based on the method of this report }\end{array}$} & \multicolumn{3}{|c|}{$\begin{array}{c}\text { DTN: SN0307T0510902.003 } \\
\text { (output DTN) } \\
\text { incorporates corrections and changes } \\
\text { required by the checking process } \\
\text { per AP-SIll.9Q }\end{array}$} \\
\hline 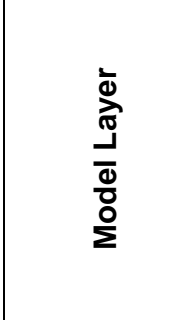 & 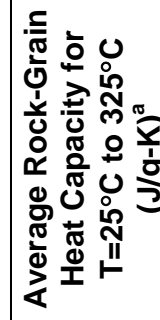 & 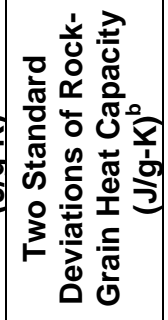 & 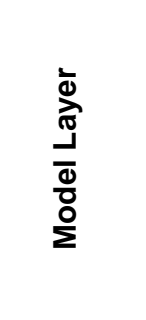 & 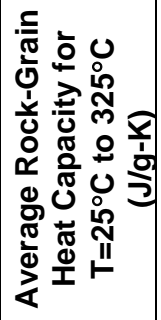 & 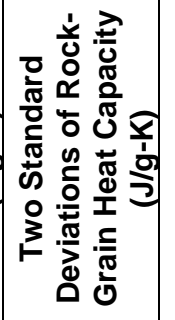 & 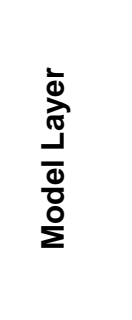 & 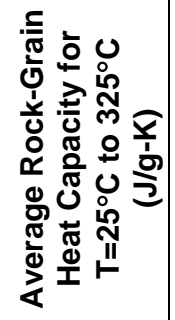 & 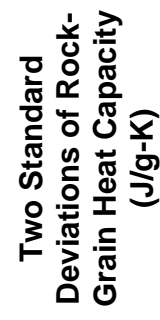 & 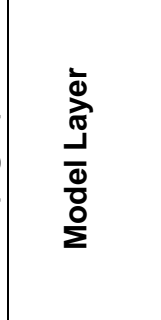 & 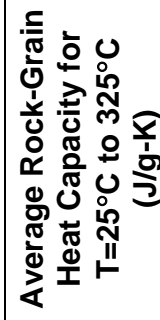 & 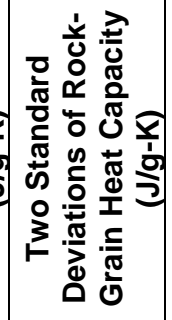 \\
\hline Tptpv2 & 1.040 & 0.254 & & & & Tptpv2 & 0.98 & 0.44 & Tptpv2 & 0.98 & 0.38 \\
\hline Tptpv1 & 1.040 & 0.254 & & & & $\begin{array}{c}\text { Tptpv1- } \\
\text { Tpbt1 }\end{array}$ & 1.08 & 0.94 & $\begin{array}{c}\text { Tptpv1- } \\
\text { Tpbt1 }\end{array}$ & 1.08 & 0.84 \\
\hline Tpbt1 & 1.040 & 0.254 & & & & & & & & & \\
\hline \multirow[t]{4}{*}{ Calico } & 1.038 & 0.176 & & & & Tac4 & 1.07 & 0.94 & Tac4 & 1.07 & 0.84 \\
\hline & & & & & & Tac3 & 1.07 & 0.84 & Tac3 & 1.07 & 0.76 \\
\hline & & & & & & Tac2 & 1.08 & 0.82 & Tac2 & 1.07 & 0.72 \\
\hline & & & & & & Tac1 & 1.08 & 0.80 & Tac1 & 1.07 & 0.70 \\
\hline Calicobt & 1.038 & 0.176 & & & & Tacbt & 1.02 & 0.54 & Tacbt & 1.02 & 0.48 \\
\hline Prowuv & 1.040 & 0.254 & Tcpuv & 1.046 & 0.4 & Tcpuv & 1.04 & 0.64 & Tcpuv & 1.04 & 0.56 \\
\hline Prowuc & 1.040 & 0.254 & Tcpuclc & 0.934 & 0.2 & $\begin{array}{c}\text { Tcpuc- } \\
\text { Tcplc }\end{array}$ & 0.93 & 0.34 & $\begin{array}{c}\text { Tcpuc- } \\
\text { Tcplc }\end{array}$ & 0.93 & 0.26 \\
\hline Prowmd & 0.985 & 0.202 & Tcplvuv & 1.107 & 0.4 & $\begin{array}{l}\text { Tcplv- } \\
\text { Tcbuv }\end{array}$ & 1.11 & 0.48 & $\begin{array}{l}\text { Tcplv- } \\
\text { Tcbuv }\end{array}$ & 1.10 & 0.38 \\
\hline Prowlc & 1.040 & 0.254 & & & & & & & & & \\
\hline Prowlv & 1.040 & 0.254 & & & & & & & & & \\
\hline Prowbt & 1.040 & 0.254 & & & & & & & & & \\
\hline Bullfroguv & 1.040 & 0.254 & Tcbuclc & 0.935 & 0.2 & $\begin{array}{c}\text { Tcbuc- } \\
\text { Tcblc }\end{array}$ & 0.93 & 0.30 & $\begin{array}{c}\text { Tcbuc- } \\
\text { Tcblc } \\
\end{array}$ & 0.93 & 0.24 \\
\hline Bullfroguc & 1.040 & 0.254 & Tcblvuv & 1.05 & 0.4 & $\begin{array}{l}\text { Tcblv- } \\
\text { Tctuv }\end{array}$ & 1.05 & 0.52 & $\begin{array}{l}\text { Tcblv- } \\
\text { Tctuv }\end{array}$ & 1.05 & 0.44 \\
\hline Bullfrogmd & 0.985 & 0.202 & & & & & & & & & \\
\hline Bullfroglc & 1.040 & 0.254 & & & & & & & & & \\
\hline
\end{tabular}


Table B-1. Comparison of Oxide and Mineral Summation Methods for Rock-Grain Heat Capacity (Continued)

\begin{tabular}{|c|c|c|c|c|c|c|c|c|c|c|c|}
\hline \multicolumn{3}{|c|}{$\begin{array}{c}\text { DTN: SN0402T0503102.010 } \\
\text { [DIRS 170993] } \\
\text { based on major element oxide data }\end{array}$} & \multicolumn{3}{|c|}{$\begin{array}{l}\text { DTN SN0210T0510902.001 } \\
\text { [DIRS 161244] } \\
\text { based on mineral summation method }\end{array}$} & \multicolumn{3}{|c|}{$\begin{array}{c}\text { DTN: SN0303T0510902.002 } \\
\text { [DIRS 162496] } \\
\text { based on the method of this report }\end{array}$} & \multicolumn{3}{|c|}{$\begin{array}{c}\text { DTN: SN0307T0510902.003 } \\
\text { (output DTN) } \\
\text { incorporates corrections and changes } \\
\text { required by the checking process per } \\
\text { AP-SIll.9Q }\end{array}$} \\
\hline 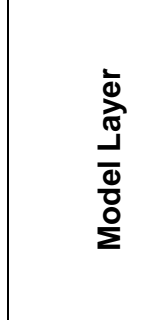 & 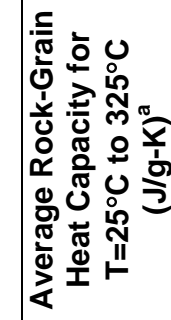 & 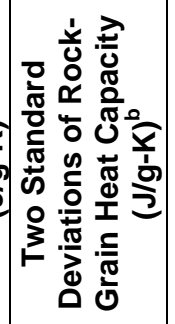 & 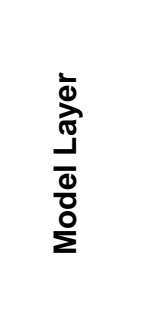 & 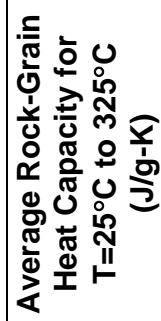 & 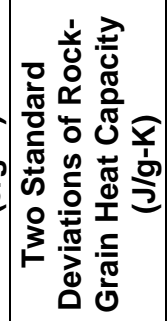 & 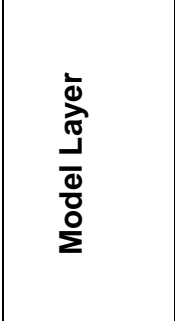 & 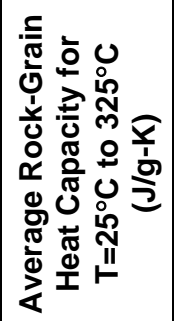 & 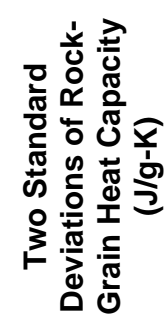 & 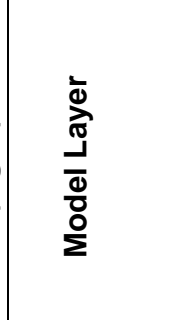 & 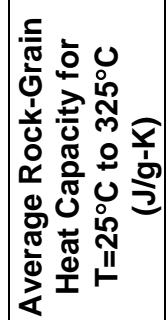 & 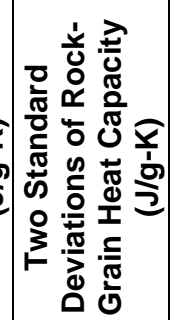 \\
\hline Bullfroglv & 1.040 & 0.254 & & & & & & & & & \\
\hline Bullfrogbt & 1.040 & 0.254 & & & & & & & & & \\
\hline Tramuv & 1.040 & 0.254 & Tctuclc & 0.936 & 0.2 & $\begin{array}{l}\text { Tctuc-- } \\
\text { Tctlc }\end{array}$ & 0.94 & 0.32 & $\begin{array}{l}\text { Tctuc- } \\
\text { Tctmd- } \\
\text { Tctlc } \\
\end{array}$ & 0.94 & 0.24 \\
\hline Tramuc & 1.040 & 0.254 & Tctlvbt & 0.936 & 0.2 & Tctlv-Tctbt & 0.94 & 0.32 & Tctlv-Tctbt & 0.94 & 0.24 \\
\hline Trammd & 0.985 & 0.202 & & & & & & & & & \\
\hline Tramlc & 1.040 & 0.254 & & & & & & & & & \\
\hline Tramlv & 1.040 & 0.254 & & & & & & & & & \\
\hline \multirow[t]{2}{*}{ Trambt } & 1.040 & 0.254 & & & & & & & & & \\
\hline & & & Tund & 0.964 & 0.2 & Tund & 0.96 & 0.34 & Tund & 0.96 & 0.26 \\
\hline
\end{tabular}

${ }^{a}$ The heat capacity values given in DTN: SN0402T0503102.010 [DIRS 170993] have units of J/kg K. To facilitate the comparison with the values given other columns of Table B-1 these values were converted to $\mathrm{J} / \mathrm{g} \mathrm{K}$.

${ }^{b}$ DTN: SN0402T0503102.010 [DIRS 170993] gives the standard deviation of the heat capacity. The standard deviation values given in the DTN were multiplied by 2 to obtain the values given in this column. 